Prepared in cooperation with the Bureau of Reclamation

\title{
Surface-Water Salinity in the Gunnison River Basin, Colorado, Water Years 1989 through 2007
}

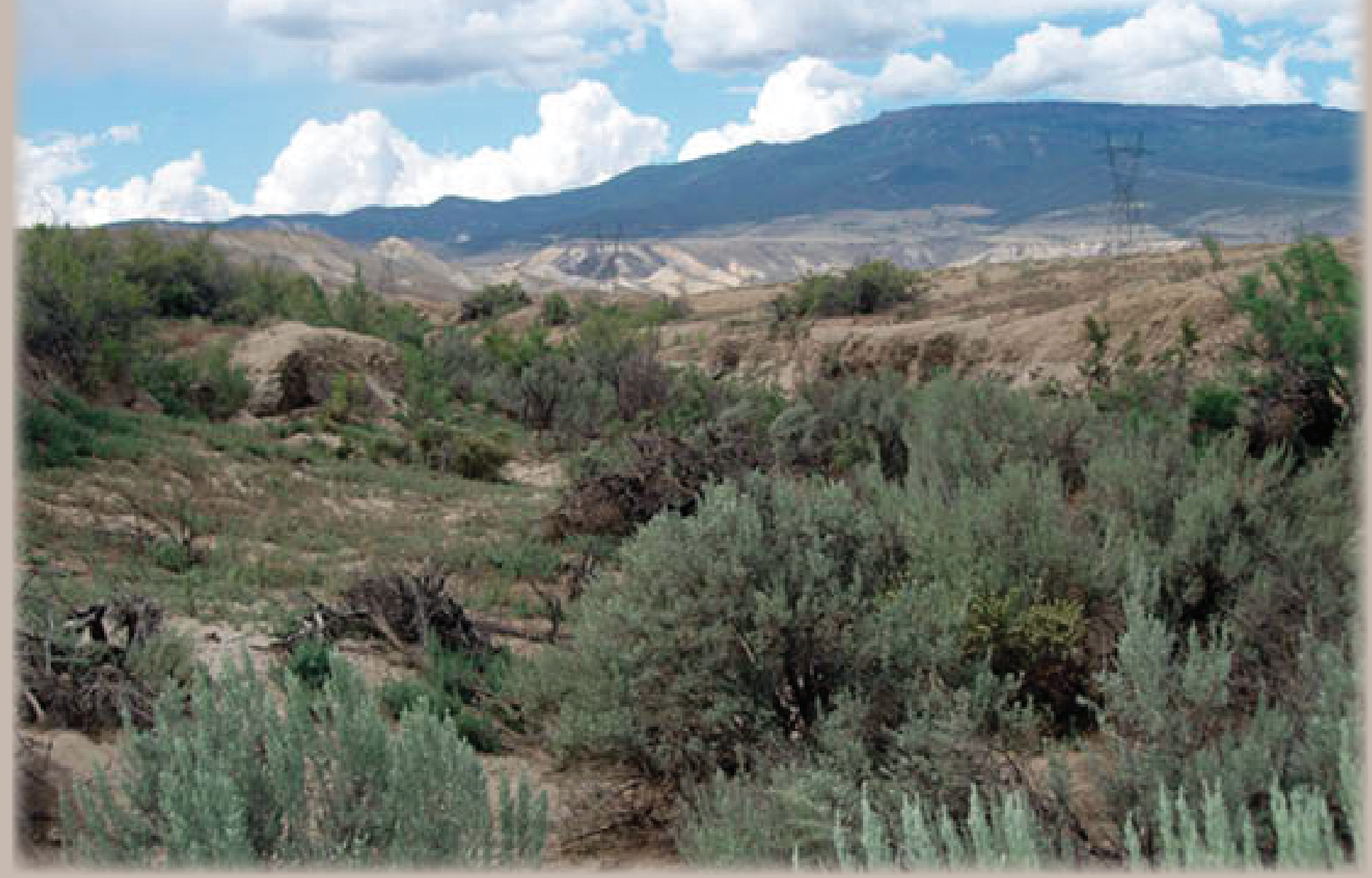

Scientific Investigations Report 2012-5128 
Cover. Dry creek bed with Mancos Shale hills and the Grand Mesa in the background north of Delta, Colorado, 2010 (photograph taken by Rod Richards, U.S. Geological Survey). 


\section{Surface-Water Salinity in the Gunnison River Basin, Colorado, Water Years 1989 through 2007}

By Keelin R. Schaffrath

Prepared in cooperation with the Bureau of Reclamation

Scientific Investigations Report 2012-5128 


\title{
U.S. Department of the Interior \\ KEN SALAZAR, Secretary \\ U.S. Geological Survey \\ Marcia K. McNutt, Director
}

\author{
U.S. Geological Survey, Reston, Virginia: 2012
}

For more information on the USGS - the Federal source for science about the Earth, its natural and living resources, natural hazards, and the environment, visit http://www.usgs.gov or call 1-888-ASK-USGS.

For an overview of USGS information products, including maps, imagery, and publications, visit http://www.usgs.gov/pubprod

To order this and other USGS information products, visit http://store.usgs.gov

Any use of trade, product, or firm names is for descriptive purposes only and does not imply endorsement by the U.S. Government.

Although this report is in the public domain, permission must be secured from the individual copyright owners to reproduce any copyrighted materials contained within this report.

Suggested citation:

Schaffrath, K.R., 2012, Surface-water salinity in the Gunnison River Basin, Colorado, water years 1989 through 2007: U.S. Geological Survey Scientific Investigations Report 2012-5128, 47 p. 


\section{Contents}

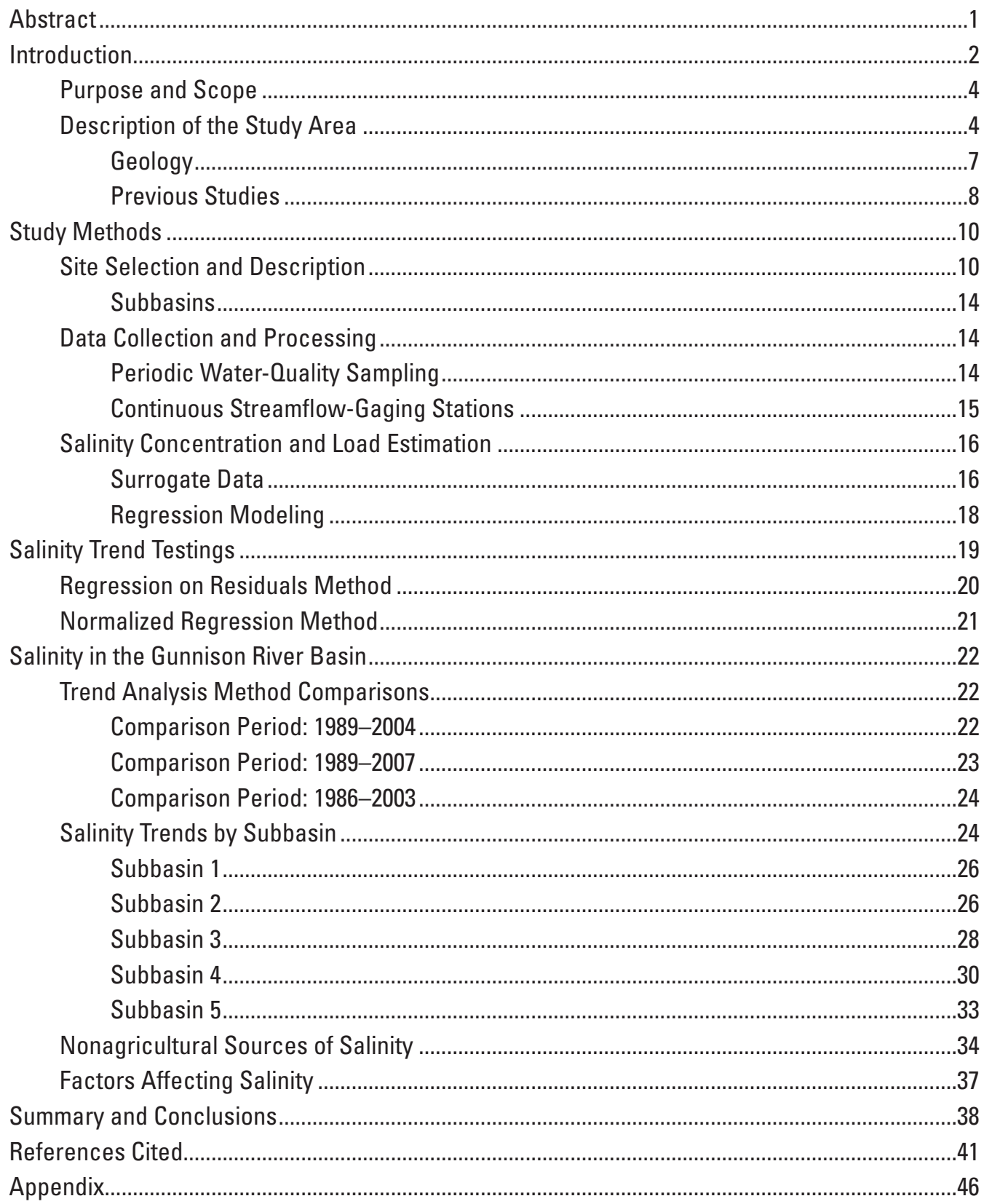

\section{Figures}

1. Map showing Gunnison River Basin study area, Colorado …………...................................

2. Map showing upper Gunnison portion of the study area, Colorado ....................................5

3. Map showing lower Gunnison portion of the study area, Colorado .....................................

4. Mean annual hydrograph of selected sites on the Gunnison and Uncompahgre Rivers, Colorado, for water years 1989 through 2004 ................................7 
5. Map showing geology of the Gunnison River Basin, Colorado..

6. Graph showing estimated annual salinity load, annual salinity load had there been no time trend, and the trend line for the flow-normalized concentration and load at streamflow-gaging station 09114500 during water years 1989-2007...

7. Graph showing estimated annual salinity load, annual salinity load had there been no time trend, and the trend line for the flow-normalized concentration and load at streamflow-gaging station 09124500 during water years 1989-2004...

8. Graph showing estimated annual salinity load, annual salinity load had there been no time trend, and the trend line for the flow-normalized concentration and load at streamflow-gaging station 09126000 during water years 1989-2004...

9. Graph showing estimated annual salinity load, annual salinity load had there been no time trend, and the trend line for the flow-normalized concentration and load at streamflow-gaging station 09128000 during water years 1989-2004.

10. Graph showing estimated annual salinity load, annual salinity load had there been no time trend, and the trend line for the flow-normalized concentration and load at streamflow-gaging station 09128000 during water years 1989-2007...

11. Graph showing estimated annual salinity load, annual salinity load had there been no time trend, and the trend line for the flow-normalized concentration and load at streamflow-gaging station 09132500 during water years 1989-2004.

12. Graph showing estimated annual salinity load, annual salinity load had there been no time trend, and the trend line for the flow-normalized concentration and load at streamflow-gaging station 09132500 during water years 1989-2007

13. Graph showing estimated annual salinity load, annual salinity load had there been no time trend, and the trend line for the flow-normalized concentration and load at streamflow-gaging station 09134000 during water years 1989-2004...

14. Graph showing estimated annual salinity load, annual salinity load had there been no time trend, and the trend line for the flow-normalized concentration and load at streamflow-gaging station 09143500 during water years 1989-2004..

15. Graph showing estimated annual salinity load, annual salinity load had there been no time trend, and the trend line for the flow-normalized concentration and load at streamflow-gaging station 09144250 during water years 1989-2004...

16. Graph showing estimated annual salinity load, annual salinity load had there been no time trend, and the trend line for the flow-normalized concentration and load at streamflow-gaging station 09147000 during water years 1989-2004

17. Graph showing estimated annual salinity load, annual salinity load had there been no time trend, and the trend line for the flow-normalized concentration and load at streamflow-gaging station 09146200 during water years 1989-2004

18. Graph showing estimated annual salinity load, annual salinity load had there been no time trend, and the trend line for the flow-normalized concentration and load at streamflow-gaging station 09146200 during water years 1989-2007

19. Graph showing estimated annual salinity load, annual salinity load had there been no time trend, and the trend line for the flow-normalized concentration and load at streamflow-gaging station 09147025 during water years 1989-2004.

20. Graph showing estimated annual salinity load, annual salinity load had there been no time trend, and the trend line for the flow-normalized concentration and load at streamflow-gaging station 09147500 during water years 1989-2004 
21. Graph showing estimated annual salinity load, annual salinity load had there been no time trend, and the trend line for the flow-normalized concentration and load at streamflow-gaging station 09149500 during water years 1989-2004.

22. Graph showing estimated annual salinity load, annual salinity load had there been no time trend, and the trend line for the flow-normalized concentration and load at streamflow-gaging station 09152500 during water years 1989-2004

23. Graph showing estimated annual salinity load, annual salinity load had there been no time trend, and the trend line for the flow-normalized concentration and load at streamflow-gaging station 09152500 during water years 1989-2007.

\section{Tables}

1. Characteristics of selected streamflow-gaging stations in the Gunnison River Basin, Colorado

2. Periodic sampling information for the selected study sites in the Gunnison River Basin, Colorado.

3. Summary of streamflow and salinity information from monitors at the natural sites included in this study in the Gunnison River Basin, Colorado.

4. Summary of results of the trend-analysis method comparisons for U.S. Geological Survey streamflow-gaging station Gunnison River near Grand Junction, Colorado ......23

5. Summary of significant results from trend analysis using normalized regression for selected sites in the Gunnison River Basin, Colorado..

6. Precipitation and salinity yield information for the selected natural sites, Gunnison River Basin, Colorado.

7. Properties from the single linear regression of specific conductance and salinity for selected U.S. Geological Survey streamflow-gaging stations within the Gunnison River Basin, Colorado.

8. Model coefficients and statistical diagnostics from regression analysis using normalized regression for salinity loads at selected at U.S. Geological Survey streamflow-gaging stations within the Gunnison River Basin, Colorado. 


\section{Conversion Factors}

\begin{tabular}{|c|c|c|}
\hline Multiply & By & To obtain \\
\hline \multicolumn{3}{|c|}{ Length } \\
\hline inch (in.) & 2.54 & centimeter $(\mathrm{cm})$ \\
\hline inch (in.) & 25.4 & millimeter $(\mathrm{mm})$ \\
\hline \multicolumn{3}{|c|}{ Area } \\
\hline acre & 4,047 & square meter $\left(\mathrm{m}^{2}\right)$ \\
\hline acre & 0.4047 & hectare (ha) \\
\hline acre & 0.004047 & square kilometer $\left(\mathrm{km}^{2}\right)$ \\
\hline square mile $\left(\mathrm{mi}^{2}\right)$ & 259.0 & hectare (ha) \\
\hline square mile $\left(\mathrm{mi}^{2}\right)$ & 2.590 & square kilometer $\left(\mathrm{km}^{2}\right)$ \\
\hline \multicolumn{3}{|c|}{ Volume } \\
\hline cubic foot $\left(\mathrm{ft}^{3}\right)$ & 0.02832 & cubic meter $\left(\mathrm{m}^{3}\right)$ \\
\hline acre-foot (acre-ft) & 1,233 & cubic meter $\left(\mathrm{m}^{3}\right)$ \\
\hline acre-foot (acre-ft) & 0.001233 & cubic hectometer $\left(\mathrm{hm}^{3}\right)$ \\
\hline \multicolumn{3}{|c|}{ Flow rate } \\
\hline acre-foot per year (acre-ft/yr) & 1,233 & cubic meter per year $\left(\mathrm{m}^{3} / \mathrm{yr}\right)$ \\
\hline acre-foot per year (acre-ft/yr) & 0.001233 & cubic hectometer per year $\left(\mathrm{hm}^{3} / \mathrm{yr}\right)$ \\
\hline cubic foot per second $\left(\mathrm{ft}^{3} / \mathrm{s}\right)$ & 0.02832 & cubic meter per second $\left(\mathrm{m}^{3} / \mathrm{s}\right)$ \\
\hline \multicolumn{3}{|c|}{ Mass } \\
\hline ton, short $(2,000 \mathrm{lb})$ & 0.9072 & megagram (Mg) \\
\hline ton per day (ton/d) & 0.9072 & metric ton per day \\
\hline $\begin{array}{l}\text { ton per day per square mile } \\
{\left[(\operatorname{ton} / \mathrm{d}) / \mathrm{mi}^{2}\right]}\end{array}$ & 0.3503 & $\begin{array}{l}\text { megagram per day per square } \\
\text { kilometer }\left[(\mathrm{Mg} / \mathrm{d}) / \mathrm{km}^{2}\right]\end{array}$ \\
\hline ton per year (ton/yr) & 0.9072 & metric ton per year \\
\hline
\end{tabular}

Vertical coordinate information is referenced to the North Geodetic Vertical Datum of 1929 (NGVD29).

Horizontal coordinate information is referenced to the North American Datum of 1983 (NAD 83).

Elevation, as used in this report, refers to distance above the vertical datum.

Specific conductance is given in microsiemens per centimeter at 25 degrees Celsius $(\mu \mathrm{S} / \mathrm{cm}$ at $\left.25^{\circ} \mathrm{C}\right)$.

Concentrations of chemical constituents in water are given in milligrams per liter (mg/L). 


\title{
Surface-Water Salinity in the Gunnison River Basin, Colorado, Water Years 1989 through 2007
}

\author{
By Keelin R. Schaffrath
}

\section{Abstract}

Elevated levels of dissolved solids in water (salinity) can result in numerous and costly issues for agricultural, industrial, and municipal water users. The Colorado River Basin Salinity Control Act of 1974 (Public Law 93-320) authorized planning and construction of salinity-control projects in the Colorado River Basin. One of the first projects was the Lower Gunnison Unit, a project to mitigate salinity in the Lower Gunnison and Uncompahgre River Basins.

In cooperation with the Bureau of Reclamation (USBR), the U.S. Geological Survey conducted a study to quantify changes in salinity in the Gunnison River Basin. Trends in salinity concentration and load during the period water years (WY) 1989 through 2004 (1989-2004) were determined for 15 selected streamflow-gaging stations in the Gunnison River Basin. Additionally, trends in salinity concentration and load during the period WY1989 through 2007 (1989-2007) were determined for 5 of the 15 sites for which sufficient data were available. Trend results also were used to identify regions in the Lower Gunnison River Basin (downstream from the Gunnison Tunnel) where the largest changes in salinity loads occur. Additional sources of salinity, including residential development (urbanization), changes in land cover, and natural sources, were estimated within the context of the trend results. The trend results and salinity loads estimated from trends testing also were compared to USBR and Natural Resources Conservation Service (NRCS) estimates of off-farm and on-farm salinity reduction from salinity-control projects in the basin. Finally, salinity from six additional sites in basins that are not affected by irrigated agriculture or urbanization was monitored from WY 2008 to 2010 to quantify what portion of salinity may be from nonagricultural or natural sources.

In the Upper Gunnison area, which refers to Gunnison River Basin above the site located on the Gunnison River below the Gunnison Tunnel, estimated mean annual salinity load was 110,000 tons during WY 1989-2004. Analysis of both study periods (WY 1989-2004 and WY 1989-2007) showed an initial decrease in salinity load with a minimum in 1997. The net change over either study period was only significant during WY 1989-2007. Salinity load significantly decreased at the Gunnison River near Delta by 179,000 tons during WY 1989-2004. Just downstream, the Uncompahgre River enters the Gunnison River where there also was a highly significant decrease in salinity load of 55,500 tons. The site that is located at the mouth of the study area is the Gunnison River near Grand Junction where the decrease was the largest. Salinity loads decreased by 247,000 tons during WY 19892004 at this site though the decrease attenuated by 2007 and the net change was a decrease of 207,000 tons.

The trend results presented in this study indicate that the effect of urbanization on salinity loads is difficult to discern from the effects of irrigated agriculture and that natural sources contribute a fraction of the total salinity load for the entire basin. Based on the calculated yields and geology, 2363 percent of the estimated annual salinity load was from natural sources at the Gunnison River near Grand Junction during WY 1989-2007. The largest changes in salinity load occurred at the Gunnison River near Grand Junction as well as the two sites located in Delta: the Gunnison River at Delta and the Uncompahgre River at Delta. Those three sites, especially the two sites at Delta, were the most affected by irrigated agriculture, which was observed in the estimated mean annual loads. Irrigated acreage, especially acreage underlain by Mancos Shale, is the target of salinity-control projects intended to decrease salinity loads.

The NRCS and the USBR have done the majority of salinity control work in the Lower Gunnison area of the Gunnison River Basin, and the focus has been in the Uncompahgre River Basin and in portions of the Lower Gunnison River Basin (downstream from the Gunnison Tunnel). According to the estimates from the USBR and NRCS, salinity-control projects may be responsible for a reduction of 117,300 tons of salinity as of 2004 and 142,000 tons as of 2007 at the Gunnison River near Grand Junction, Colo. (streamflowgaging station 09152500). USBR and NRCS estimates account for all but 130,000 tons in 2004 and 65,000 tons in 2007 of salinity load reduction. The additional reduction could be a reduction in natural salt loading to the streams because of land-cover changes during the study period. It is possible also that the USBR and NRCS have underestimated changes in salinity loads as a result of the implementation of salinitycontrol projects. 


\section{Introduction}

Elevated concentrations of dissolved mineral salts or dissolved solids in water (salinity) can result in numerous and costly issues for agricultural, industrial, and municipal water users and managers. These issues include the suitability of the water for various uses, changes in taste and odor, and corrosion of infrastructures. Agricultural losses can occur when salinity concentrations reach 700-850 milligrams per liter (Butler and von Guerard, 1996). Annually, more than 6 million tons of dissolved solids are discharged from the Colorado River Basin upstream from Lees Ferry, Arizona. Agricultural activities contribute 40-45 percent of the load while the remainder is attributed to domestic use, municipal use, and natural sources (Kenney and others, 2009). Some authors have suggested that the contribution from domestic and municipal sources is negligible in some areas (Iorns and others, 1965; Kenney and others, 2009).

Streamflow and water chemistry are controlled by the geology, land cover, land use, and precipitation characteristics in the basin (Kenney and others, 2009). The natural sources of salinity in the Colorado River Basin are related to the underlying geology. Natural point sources of salinity include seeps or saline springs that originate from geological formations with high salt content. Natural nonpoint sources generally originate from the weathering and dissolution of the same geologic formations (Prairie and others, 2005). Salts and trace elements are mobilized through dissolution, surface runoff, and percolation into the groundwater system that discharges to the river system as base flow (Kanzer and Merritt, 2008). The application of irrigation water to these agricultural lands increases the natural rate at which solids in the bedrock are dissolved and transported to streams (Prairie and others, 2005; Kenney and others, 2009). Irrigation of agricultural lands, particularly those lands underlain by geologic materials having high salt content, is the major anthropogenic source of salinity in the Colorado River Basin (Iorns and others, 1965; Mueller and Osen, 1988; Liebermann and others, 1989; Prairie and others, 2005; Kenney and others, 2009).

In 1974, the Colorado River Basin Salinity Control Act (Public Law 93-320) was enacted in response to the elevated salinity in the Lower Colorado River Basin (Butler, 1996). The act authorized the Department of the Interior, acting through the Bureau of Reclamation (USBR), to construct and plan salinity-control projects in the Colorado River Basin. One of the first projects authorized under this act was in the Lower Gunnison Unit, which encompasses the irrigated farmland in the North Fork of the Gunnison River and Uncompahgre River valleys and irrigated areas north and east of Delta along the Gunnison River (Leib and Bauch, 2008; Bureau of Reclamation, 2009, 2010). The project began mitigation of salinity in 1988 in the Uncompahgre basin and other areas in the Lower Gunnison River Basin downstream from the Gunnison Tunnel (fig. 1).

Previous salinity studies aided in the prioritization of project areas. Butler (1996) estimated that the mean annual salinity load in the Colorado River near the Colorado-Utah state line was about 3.32 million tons for water years 1970 through 1993. (A water year (WY) begins on October 1 of the previous year and ends the following September 30 and is designated by the year in which it ends.) A subsequent study by Leib and Bauch (2008) found that the mean annual salinity load was 2.89 million tons at the same site from WY 1986 through WY 2003. Both studies estimated that about 38 percent of that load was from the Gunnison River (Butler, 1996; Leib and Bauch, 2008). The Gunnison River Basin is located in western Colorado and the Gunnison River flows into the Colorado River near Grand Junction, Colo. (fig. 1).

As part of the Colorado River Basin Salinity Control Act, the USBR is responsible for "off-farm improvements" to water-distribution systems. Off-farm improvements include the elimination of stock-watering areas by making water available through an existing domestic water system that is used to fill stock-water tanks and the installation of pipes or placement of a non-permeable layer (lining) in irrigation canals (Bureau of Reclamation, 2010). These improvements are estimated to reduce salinity loading from the canals system by about 30 percent (Bureau of Reclamation, 2010).

In 1984, an amendment to the original 1974 law provided separate authority for implementation of salinity-control projects by the Natural Resources Conservation Service (NRCS) of the U.S. Department of Agriculture. The NRCS works with landowners directly and implements "on-farm improvements" to irrigation systems. In 1988, this work was initiated in the Gunnison River Basin (U.S. Department of Agriculture, 2007). The NRCS estimates the effects of the improvements based on the monitored optimum efficiency of water use; optimum efficiency refers to the most efficient use of water based on proper implementation and management of the irrigation system (Brian Sorensen, Natural Resources Conservation Service, oral. commun., 2010). The most efficient use of water (100-percent efficiency) would be when the water applied by irrigation is equal to the water needed by the vegetation and no runoff or deep percolation would result from irrigation.

The main improvements to irrigation systems include the installation of underground pipelines with gated pipes (50-55-percent efficiency) and installation of sprinkler systems (70-90-percent efficiency) (U.S. Department of Agriculture, 2007; Bureau of Reclamation, 2009). In comparison, flood irrigation has an optimal efficiency of 30-35 percent; this method was the most commonly used irrigation system before NRCS began working with the farmers (Brian Sorensen, NRCS, oral commun., 2010).

The Colorado River Basin Salinity Control Forum was established in 1973 by the seven states in the Colorado River Basin (Wyoming, Colorado, New Mexico, Utah, Arizona, Nevada, and California) (U.S. Department of Agriculture, 2010). It is composed of representatives from each State appointed by that State's governor. The Colorado River Basin Salinity Control Forum identified a need to better understand the effects of salinity-control projects and land-use changes. To understand the effects of salinity-control projects and 


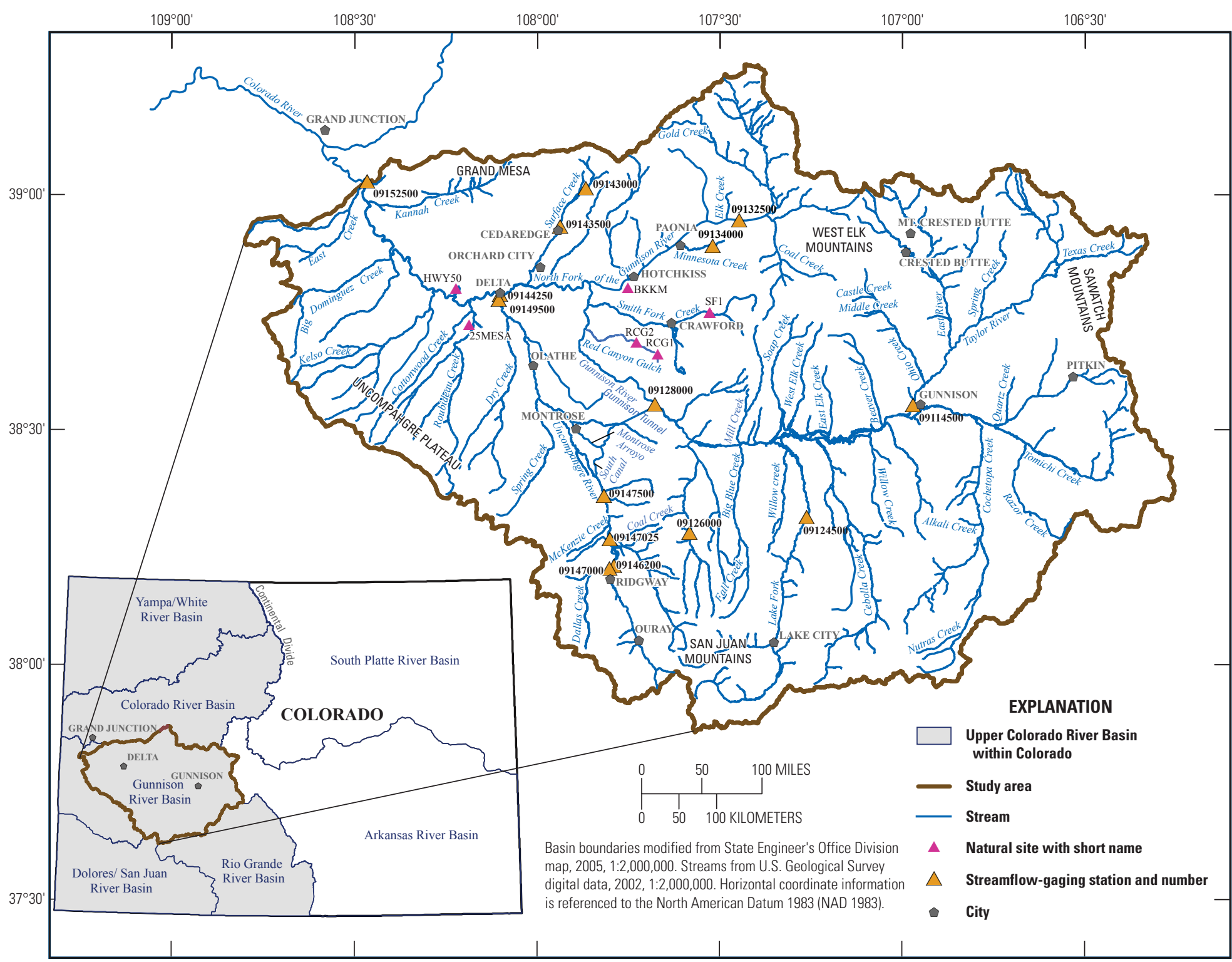

Figure 1. Gunnison River Basin study area, Colorado. 
Surface-Water Salinity in the Gunnison River Basin, Colorado, Water Years 1989 through 2007

land-use changes, the U.S. Geological Survey (USGS), in cooperation with the USBR, quantified changes in salinity in the Gunnison River and other rivers and streams in the Gunnison River Basin during WY 1989 through WY 2007. Specific objectives of the study were to (1) compare agricultural amounts determined from trends testing to on-farm and offfarm salinity reduction estimates from the USBR and NRCS; (2) quantify the salinity load from the Upper Gunnison River Basin, defined as the portion of the basin upstream from the Gunnison Tunnel (fig. 2); and (3) apportion changes in salinity loads into agricultural and nonagricultural amounts. The salinity load from the Upper Gunnison River Basin is considered to be a surrogate for the effects of population growth (urbanization), which is equivalent to the contribution from domestic and municipal sources.

\section{Purpose and Scope}

The primary objective of this report was to quantify changes in salinity in the Gunnison River and other rivers and streams in the Gunnison River Basin during WY 1989 through WY 2007 in order to understand the effects of salinity-control projects and land-use change. This report documents the methods and results of an analysis of salinity from 21 sites in the Gunnison River Basin. Trends in salinity loads during the period WY 1989 through WY 2004 (1989-2004) were determined for 15 selected streamflow-gaging stations in the Gunnison River Basin (fig. 1). Additionally, trends in salinity concentration and load during the period WY 1989 through WY 2007 (1989-2007) were determined for 5 of the 15 sites where sufficient data were available for trend analysis. Waterquality data from the USGS National Water Information System were retrieved for the analyses in this report. Trend results were used to identify regions in the Lower Gunnison River Basin (fig. 3) where the largest changes in salinity concentration and load occurred. Additional sources of salinity, including municipal and domestic sources (urbanization), changes in land cover, and natural sources, were estimated within the context of trend results. The trend results and salinity loads estimated from trend testing also were compared to USBR and NRCS estimates of off-farm and on-farm salinity reduction from salinity-control projects in the Lower Gunnison portion of the study area.

This report also documents the methods used to monitor six unirrigated areas and to estimate annual salinity loads for each of those areas. The results were used to estimate the natural component of salinity load for the entire study basin. To understand the salinity load from unirrigated areas, salinity loads were calculated for six unirrigated sites; four were monitored from 2008 to 2009 and the other two were monitored from 2008 through 2010.

Previous studies used a methodology, referred to as "regression on residuals," to account for the variability due to streamflow and to test for the time trend. This report documents a different method, referred to as "normalized regression" that accounts for the variability due to streamflow at an earlier stage in the trend analysis and provides a comparison of the two methods.

\section{Description of the Study Area}

The Gunnison River is the largest tributary to the Colorado River in Colorado (fig. 1) (Liebermann and others, 1989). It is located west of the Continental Divide and flows into the Colorado River at Grand Junction. The drainage area of the Gunnison River Basin is about 8,000 square miles $\left(\mathrm{mi}^{2}\right)$. The headwaters of the Gunnison River are in the West Elk, Sawatch, and San Juan Mountains. Elevations range from about 4,600 feet at the mouth of the river to more than 14,000 feet in the San Juan and West Elk Mountains located in the south and northeast parts of the study area, respectively.

In 2000, the major population centers in the study area included Montrose (population 12,344), Delta (population 6,400), and Gunnison (population 5,409) (U.S. Census Bureau, 2010). No other population center in the study area exceeded 3,000 inhabitants. All of the population centers showed an increase in population since the 1990 census count; most saw an increase of at least 20 percent. Population continued to increase between 2000 and 2010, but the increases generally were smaller and most populations grew by less than 20 percent (U.S. Census Bureau, 2010).

A large percentage of land in the study area is owned and managed by the U.S. Forest Service. The Grand Mesa, Uncompahgre, and Gunnison National Forests cover more than $3,600 \mathrm{mi}^{2}$ of the study area and are generally located in the higher elevations of the study area. More than 2,200 $\mathrm{mi}^{2}$ are owned privately and more than $2,000 \mathrm{mi}^{2}$ are owned by the Bureau of Land Management. The National Park Service (Black Canyon of the Gunnison National Park) and state and local entities own the remainder of land in the study area (Bureau of Land Management, 2009).

Generally, land cover in the study area is classified as either forest, grassland, agriculture, or urban as defined by the 1992 and 2001 National Land Cover Databases (NLCD) (Vogelmann and others, 2001; Homer and others, 2004). The 2001 NLCD indicated that more than 80 percent of the land cover in the study area was classified as forest or grassland (grassland includes the shrub/scrub category of the NLCD). Pasture/hay and cultivated crops accounted for about 12 percent of the study area (Vogelmann and others, 2001; Homer and others, 2004). Between 1992 and 2001, only 3 percent of the land cover in the study area changed classification; changes were determined using a geographic information system and the NLCD Change Product which was developed to better compare the 1992 and 2001 NLCD datasets (Fry and others, 2009). However, Fry and others (2009) stated that the accuracy of the product was not formally assessed. In the final product, agriculture land covers included classifications for orchards, vineyards, and other; pasture/hay; row crops; small grains; and fallow. The grassland, herbaceous, or 


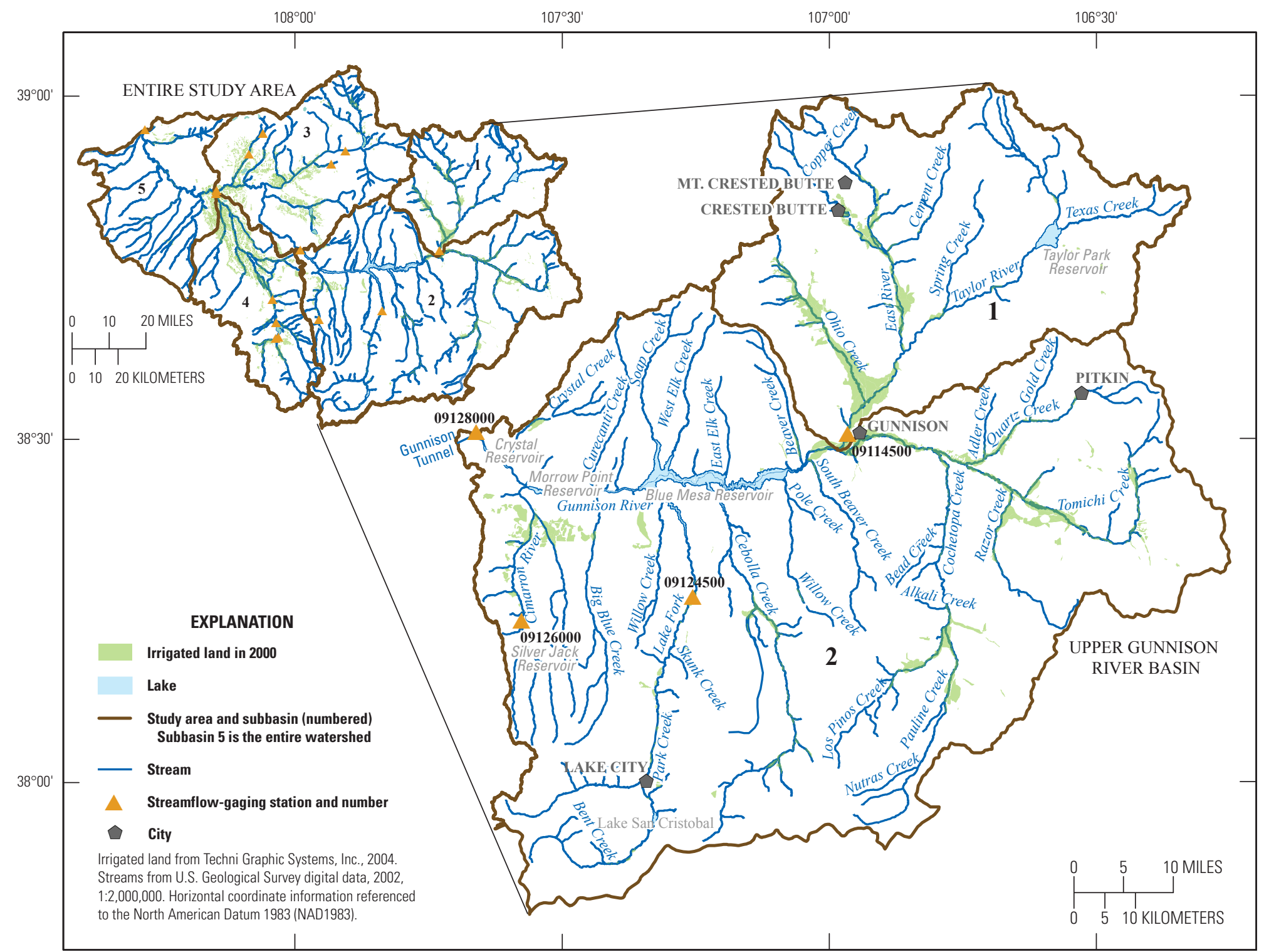

Figure 2. Upper Gunnison portion of the study area, Colorado. 


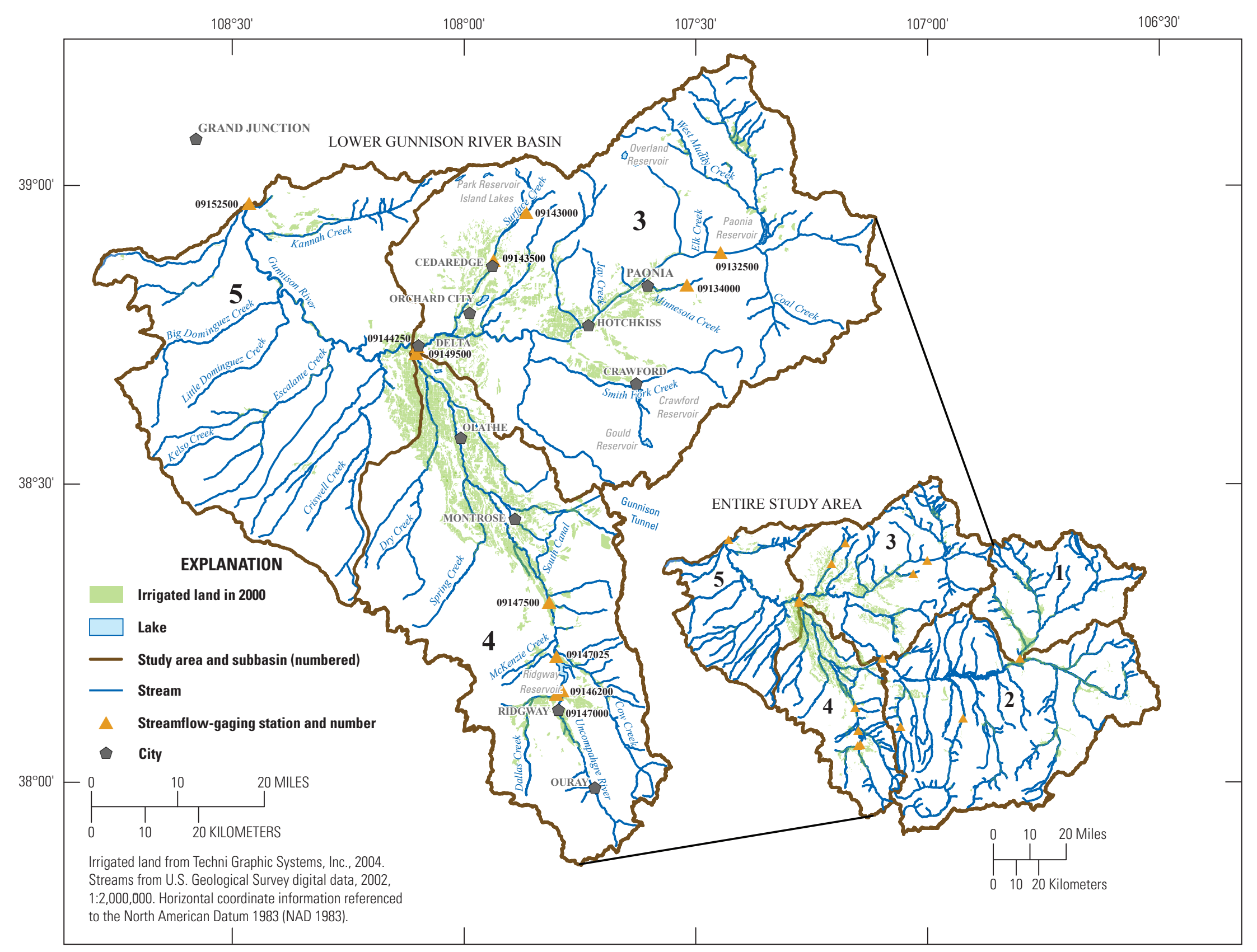

Figure 3. Lower Gunnison portion of the study area, Colorado. 
transitional barren land covers were classified separately (Fry and others, 2009). According to the NLCD Change Product, land classified as agriculture in the study area increased by more than $56 \mathrm{mi}^{2}$ between 1992 and 2001 whereas land classified as urban increased by about $9 \mathrm{mi}^{2}$. The largest net losses were forests $\left(23 \mathrm{mi}^{2}\right)$ and grasslands (more than $46 \mathrm{mi}^{2}$ ) which included the shrub/scrub land cover (Fry and others, 2009). Areas classified as grassland did increase in the Upper Gunnison River Basin (upstream from the Gunnison Tunnel) and in the North Fork of the Gunnison River Basin (north of Delta, Colo.) (fig. 1). Decreases in forested land cover classifications were much more substantial at higher elevations of the study basin. In the Uncompahgre River Basin and the Gunnison River Basin (downstream from Delta, Colo.), forested land cover increased and losses of grassland were much larger (Fry and others, 2009).

Agricultural irrigation in the study area has existed since 1890. By 2000, almost $415 \mathrm{mi}^{2}$ of farmland were irrigated in some manner (figs. 2 and 3) (Techni Graphic Systems, Inc., 2004). Flood and furrow irrigation $\left(340 \mathrm{mi}^{2}\right)$ were the most widely used methods; whereas, irrigation by sprinklers $\left(6 \mathrm{mi}^{2}\right)$ accounted for only a small portion of the irrigated acreage (Techni Graphic Systems, Inc., 2004). Additionally, more than $65 \mathrm{mi}^{2}$ of land was irrigated using unknown methods and the small remainder of land was irrigated using drip and gatedpipe irrigation methods (Techni Graphic Systems, Inc., 2004). The irrigated-acreage data collected in 1993 and 2000 were "snapshots" only and were not intended to be used to determine if land was completely taken out of production or just fallowed in the year of the snapshot (Carolyn Fritz, GIS Coordinator, Colorado Water Conservation Board, written commun., 2010). Throughout this report, however, the irrigated acreages in 1993 and 2000 are presented in terms of change despite the intended use of the product.

The climate of the area is semiarid. In the lower elevations, the majority of precipitation falls as rain in late summer and early fall (July through September) and temperatures generally are warmer relative to the high elevations. In the higher elevations, the majority of precipitation falls as snow and is stored as snowpack. Located in the lower elevations, at about 4,930 feet, Delta has an average annual precipitation of 8.01 inches and average annual temperatures range from 33.7 to 67.1 degrees Fahrenheit (Western Regional Climate Center, 2010). Located in the higher elevations, at about 8,865 feet, Crested Butte has an average annual precipitation of 23.5 inches and an average annual snowfall of 198 inches. Average annual minimum temperature is 17.9 degrees Fahrenheit and the average annual maximum is 51.5 degrees Fahrenheit (Western Regional Climate Center, 2010).

Spring snowmelt dominates the annual streamflow pattern (fig. 4). Streamflow begins to increase in March or April, peaks between May and June, and decreases in July and August. In the lower elevations, smaller increases in streamflow can occur in July and August as a result of summer thunderstorms. Exceptions to the snowmelt hydrograph result from controlled releases from the reservoirs in the study area. Figure 4 illustrates

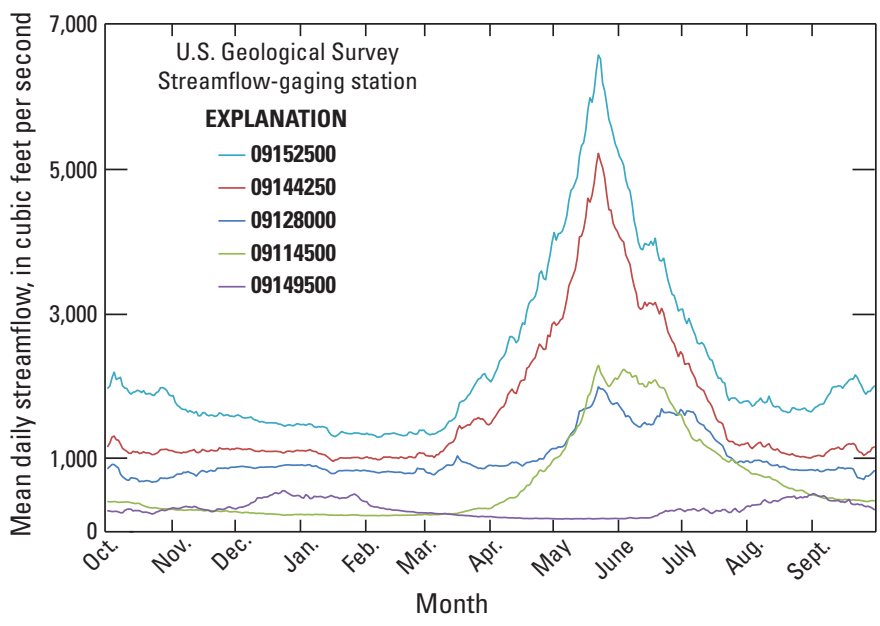

Figure 4. Mean annual hydrograph of selected sites on the Gunnison and Uncompahgre Rivers, Colorado, for water years 1989 through 2004.

the annual hydrograph for the period WY 1989 through WY 2009 for four streamflow-gaging sites located on the Gunnison River and one site on the Uncompahgre River. The site on the Uncompahgre River is located just upstream from where the Uncompahgre River enters the Gunnison River in Delta.

Taylor Park Reservoir (106,200 acre-ft) is the furthestupstream reservoir on the Gunnison River (fig. 2). The reservoir is located about 31 miles upstream from the streamflow-gaging station Gunnison River at Gunnison (09114500). Located west of Gunnison, the Wayne N. Aspinall Unit (Aspinall Unit) is a series of three reservoirs situated along a 40-mile reach of the Gunnison River. The reservoirs are intended for water storage and hydroelectric power generation. The Aspinall Unit consists of Blue Mesa Reservoir (829,500 acre-ft), Morrow Point Reservoir (117,000 acre-ft), and Crystal Reservoir (17,500 acre-ft). The Aspinall Unit has decreased the peak streamflows in the Gunnison River relative to pre-reservoir peak streamflows; however, annual streamflows generally are unaffected (Leib and Bauch, 2008). Ridgway Reservoir (83,000 acre-ft) is on the Uncompahgre River below Ridgway. The annual hydrograph of the Uncompahgre River site (09149500) was affected considerably by Ridgway Reservoir and water requirements during the irrigation season (April through October) (fig. 4).

\section{Geology}

This study area is bordered by four major structural features. The features include the Uncompahgre Plateau located in the southwest part of the area, the north-dipping southwestern flank of the Grand Mesa and West Elk Mountains to the north, the Sawatch Mountains in the northeast, and the San Juan Mountains in the south (Brooks and Ackerman, 1985; Day and Bove, 2003).

The surface geology of the study area ranges in age from Precambrian to Quaternary (Tweto, 1979; Green, 1992) (fig. 5). The Precambrian-aged formations are composed of igneous 
and metamorphic rocks and are found predominantly in the higher mountain areas of the Sawatch Range and San Juan Mountains. The Upper Triassic-aged Kayenta, Wingate, and Chinle Formations are found sparingly in the valley floors of the furthest southern and western tributaries to the Gunnison River downstream from the Uncompahgre Basin. These sandstone formations are eolian deposits in the form of dunes and are not known to produce high salinity in streams (Day and Bove, 2003). The Jurassic-aged Morrison, Wanakah, and Entrada Formations consist primarily of sandstone and are found mostly on the valley walls of the southwestern tributaries to the Gunnison River. The Entrada Formation is an eolian deposit and not a known source of salinity to streams (Day and Bove, 2003). The Morrison Formation includes the Brushy Basin Member and the Salt Wash Member. The formation was most likely deposited by changing fluvial processes dominated by stream influx and lake and flood-plain sedimentation (Day and Bove, 2003).

In the transition between the Upper Jurassic and Lower Cretaceous periods, low-gradient streams meandered across flood plains, mud flats, and saline basins, and deposited the Burro Canyon Formation (Day and Bove, 2003). During the Lower Cretaceous period, the Western Interior Basin migrated eastward and deposited beach sands with intervening carbonaceous shales that make up the Dakota Sandstone (Day and Bove, 2003). The Burro Canyon Formation and Dakota Sandstone crop out in some areas of the eastern and central parts of the basin but are found mostly in the southwestern part. As the shoreline of the Western Interior Basin migrated eastward, deep-water marine sediments were deposited that left a thick layer of marine, black shale called Mancos Shale (Day and Bove, 2003). The Upper Cretaceous Mancos Shale is the most important contributor of salinity to the streams of the Gunnison River (Liebermann and others, 1989). The Mesaverde Group, also Upper Cretaceous in age, is made of sediments that were deposited fluvially in marshes and lagoons (Day and Bove, 2003) and is not a likely source of salinity to the streams of the study area. The majority of Tertiary-aged rocks found in the study area were deposited as a result of volcanic activity in the Sawatch Range and San Juan Mountains (Tweto, 1979; Green, 1992). These rocks cover a thick band through the center of the study area. The youngest rocks in the study area are Quaternary-aged deposits, mostly consisting of alluvium, glacial till and outwash, and landslide deposits. The Mancos Shale and Mesaverde Group particularly are prone to landslides (Bove and Day, 2003). Other than the landslide deposits of Mancos Shale origin, the Quaternary-aged deposits are not a notable source of salinity in the study area.

\section{Previous Studies}

The importance and complexity of salinity in the Gunnison River is reflected in the number of studies and publications on the topic. These efforts have included quantifying the natural component of the salinity load as well as identifying trends in salinity concentration and load over time. From
WY 1914-1957, salt loading from natural sources in the Gunnison River Basin averaged 542,000 tons per year; the results assumed the 1957 level of water-resources development (Iorns and others, 1965). Another study used a massbalance approach for the same period and reported that salinity from natural sources accounted for 463,000-481,000 tons of salt (Mueller and Osen, 1988). Both studies determined salt loads in the Gunnison River near Grand Junction, Colo. (streamflow-gaging station 09152500).

Many studies have quantified salinity trends over time for various study periods. Liebermann and others (1989) reported on salinity trends in the Gunnison River near Grand Junction based on the completion of the Blue Mesa Dam. Built in 1965, the Blue Mesa Reservoir is the largest of the three reservoirs that make up the Aspinall Unit (fig. 2). A step-trend test was used to determine whether there was a significant difference in salinity load between the pre-reservoir period (1934-1965) and the post-reservoir period (1966-1983). A negative step trend (difference between the two periods) of 119,000 tons of salt was detected for the study site as a result of the completion of Blue Mesa Reservoir. Trend tests also were conducted to detect trends within each of the two periods; however, no significant results were detected within each of the two periods (Liebermann and others, 1989). The same study also found that streamflow and salinity concentrations in the Gunnison River had decreased during the annual high-flow period (May-June) and increased during the annual low-flow period (August-March) as a result of Blue Mesa Reservoir. Additionally, a significant negative trend of 3,810 tons per year was detected at the Uncompahgre River at Delta, Colo. (streamflow-gaging station 09149500) for the period 19591980 (Liebermann and others, 1989). The annual trend represents a 28-percent decrease in median annual flow-adjusted concentration for the period 1959-1980.

Significant negative trends in flow-adjusted concentrations and annual loads were detected at the Gunnison River near Grand Junction, Colo. (streamflow-gaging station 09152500) for 1986-2003 (Leib and Bauch, 2008) and 19701993 (Butler, 1996). In the first study, annual flow-adjusted loads decreased by 202,000 tons from 1986-2003 (Leib and Bauch, 2008). In the second study, annual flow-adjusted loads decreased by an average of 6,350 tons per year, which is an overall decrease of 152,000 tons over the 24-year period tested. Using a locally-weighted scatterplot smoothing (LOWESS) curve on the monthly and annual flow-adjusted salinity loads indicated that the majority of the decrease in loads occurred prior to 1980 (Butler, 1996). For WY 1986-1993, trends were not significant although the slope of the trend lines were negative for daily and annual flow-adjusted data. One objective of the Butler (1996) study was to determine if salinity-control projects that began in 1988 had decreased salinity loads to the Colorado River. Based on the results of the different periods tested and the LOWESS smooth curve, Butler's (1996) conclusion was that the decrease in salinity observed at the Gunnison River near Grand Junction site was not related to salinity-control projects. 


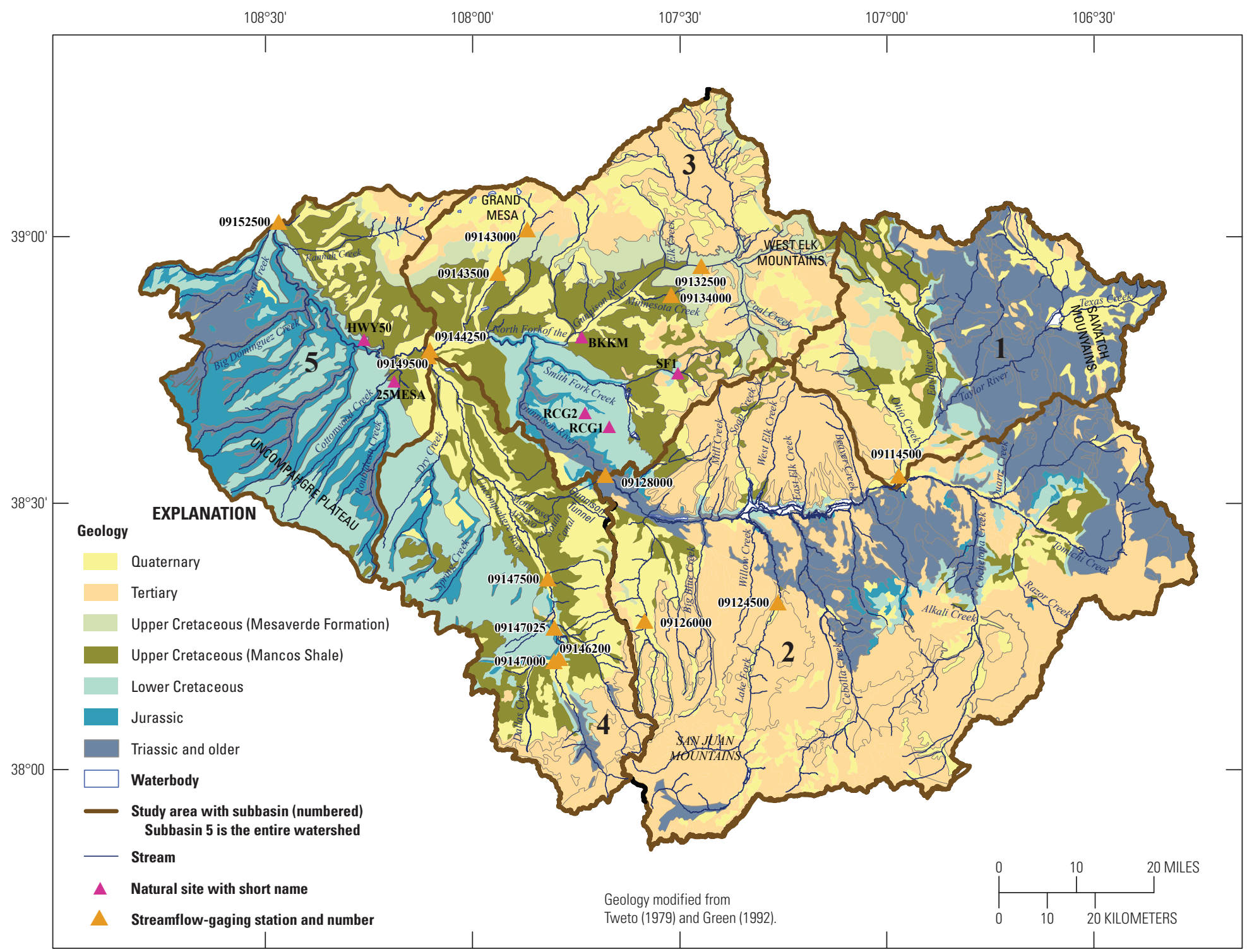

Figure 5. Geology of the Gunnison River Basin, Colorado. 
Leib and Bauch (2008), Butler (1996), and Liebermann and others (1989) calculated salinity loads using a methodology documented by Liebermann and others (1987). The method used the Salt LOAD (SLOAD) computer program to estimate daily salinity loads using streamflow and specific conductance. Daily loads were summed by month or water year to estimate monthly and annual loads. The three studies then accounted for streamflow variability by using hyperbolic regression models (Smith and others, 1982). The residuals of the regression models were tested for monotonic trends using the Seasonal Kendall test (Hirsch and others, 1991). The method is referred to as "regression on residuals" in this report.

Two recent studies focused on the effect of converting previously irrigated agricultural land to an urban land use in western Colorado. One study measured irrigation-water application on urban sites in Grand Junction, Colo. and deep percolation, where deep percolation was defined as infiltration of water below the top 12 inches of soil. The measurements were compared to data from the NRCS on irrigation-water application and deep percolation for agricultural sites that were planted with alfalfa and located near Grand Junction (Mayo, 2008). This study found that conversion of land from agricultural use to urban residential use can result in a decrease in salt loading of 90 percent per developed acre (Mayo, 2008). In the second study, salinity concentration and load were compared between two sites on the Montrose Arroyo near Montrose, Colo. (Moore, 2011). One site was upstream from increased urbanization and the other was downstream from increased urbanization. The previous land use was dominated by irrigated agriculture but included other land-use categories. There were no significant differences between salinity at the two sites, which implied that urbanization had no effect on salinity concentration and load. Between the two sites, nine ponds were constructed as part of a golf course that, depending on how the ponds were lined, may have affected salinity concentration and load. The difference in the results of the two studies indicated either that the construction of the ponds offset any decreases in salinity because of increased urbanization or that the site-specific results reported by Mayo (2008) do not scale up to the watershed-scale analysis reported by Moore (2011).

\section{Study Methods}

\section{Site Selection and Description}

Twenty-one sites were selected to meet the objectives of this study. Fifteen sites were chosen based on availability of sufficient data to measure the trends in salinity over time. These sites are referred to as "salinity trend sites" in this report (table 1, fig. 1). Six additional sites were selected to represent the salinity loads from areas that were not affected by agriculture and irrigation. These sites are referred to as "natural sites" in this report (table 1, fig. 1). The term "natural," as used in this report, indicates the portion of the load from nonpoint sources such as the underlying geology. The loads at the six natural sites were considered natural because the upstream watersheds contained no irrigated agriculture that could increase salinity loads and no population centers were located upstream from the sites.

Salinity trend sites were chosen based on the availability of data required for estimating salinity loads. Periodic and continuous data were available for each of the 15 sites. Periodic data are data collected periodically as part of a water-quality sampling effort. At least four periodic samples per year for the study period were collected at each of the 15 salinity trend sites; all samples included measurements of salinity and/or specific conductance. Continuous data are data collected at 15-minute intervals. The data were retrieved from the USGS National Water Information System (available online at http://waterdata.usgs.gov).

Periodic and continuous data were available for analysis of two study periods: WY 1989-2004 and WY 1989-2007 (table 2). As a matter of convention, the study periods stated in this report will be defined as being water year distinctions. Water year 1989 was chosen as the first year of each study period because the NRCS began applying improved irrigation systems and practices with cooperators in the study area beginning in 1988. Sufficient data were available at all 15 salinity trend sites to analyze the 1989-2004 study period. Additionally, 5 of the 15 sites had sufficient data to analyze trends for the 1989-2007 study period, so salinity trends were analyzed for these 5 sites for both study periods with the goal to compare the results and determine whether the magnitude of trends changed with the addition of the 3 years of data (WY 2005, 2006, and 2007).

The six natural sites were monitored over several different periods. Three of the sites were monitored from early May 2008 through early May or June 2009. Two other sites were monitored from early August or September 2008 through early August 2010. The last site was operated from mid July 2008 through late July 2009. Data were collected from four of the six sites as part of a study in the Smith Fork region in the Gunnison River Basin. These data were intended to account for the nonagricultural portion of the salinity load for one climate year (April 1, 2008 through March 31, 2009) and the sites were monitored only for slightly longer than one year (table 2) (R.J. Richards, U.S. Geological Survey, written commun., 2011). All six of the natural sites had continuous data available for the respective monitoring periods and five of the six sites had at least one periodic water-quality sample. The data from all six sites were used to estimate annual salinity loads.

The characteristics of the natural sites are detailed in table 1. Elevations ranged from 5,000 feet to 7,407 feet. Smith Fork near Crawford, Colo., SF1, (streamflow-gaging station 09128500) is characterized by perennial flow. The two sites located on Red Canyon Gulch, RCG1 and 
Table 1. Characteristics of selected streamflow-gaging stations in the Gunnison River Basin, Colorado.

[NA, indicates not applicable; Latitude and longitude datum: North American Datum of 1983; Elevation datum: National Geodetic Vertical Datum of 1929 (NGVD 29) (http://waterdata.usgs.gov/nwis)]

\begin{tabular}{|c|c|c|c|c|c|c|c|c|}
\hline $\begin{array}{l}\text { U.S. Geological } \\
\text { Survey streamflow- } \\
\text { gaging station } \\
\text { number, figures 1-5 }\end{array}$ & $\begin{array}{l}\text { Site short } \\
\text { name, } \\
\text { figures } 1 \\
\text { and } 5\end{array}$ & U.S. Geological Survey streamflow-gaging station name & $\begin{array}{l}\text { Latitude, } \\
\text { in decimal } \\
\text { degrees }\end{array}$ & $\begin{array}{c}\text { Longitude, } \\
\text { in decimal } \\
\text { degrees }\end{array}$ & $\begin{array}{l}\text { Elevation, } \\
\text { in feet } \\
\text { above } \\
\text { NGVD } 29\end{array}$ & $\begin{array}{l}\text { Drainage } \\
\text { area, } \\
\text { in square } \\
\text { miles }\end{array}$ & $\begin{array}{c}\text { Study } \\
\text { area } \\
\text { location, } \\
\text { figures } 2 \\
\text { and } 3\end{array}$ & $\begin{array}{r}\text { Subbasin } \\
\text { number, } \\
\text { figures 2, } \\
3 \text {, and } 5\end{array}$ \\
\hline \multicolumn{9}{|c|}{ Salinity trend sites } \\
\hline 09114500 & NA & Gunnison River near Gunnison, Colo. & 38.541936 & -106.949766 & 7,655 & 1,012 & Upper & 1 \\
\hline 09124500 & NA & Lake Fork at Gateview, Colo. & 38.298883 & -107.230056 & 7,828 & 334 & Upper & 2 \\
\hline 09126000 & NA & Cimarron River near Cimarron, Colo. & 38.258194 & -107.546111 & 8,641 & 67 & Upper & 2 \\
\hline 09128000 & NA & Gunnison River below Gunnison Tunnel, Colo. & 38.529153 & -107.648947 & 6,526 & 3,965 & Upper & 2 \\
\hline 09132500 & NA & North Fork Gunnison River near Somerset, Colo. & 38.925823 & -107.434221 & 6,280 & 526 & Lower & 3 \\
\hline 09134000 & NA & Minnesota Creek near Paonia, Colo. & 38.869989 & -107.504223 & 6,200 & 41 & Lower & 3 \\
\hline 09143000 & NA & Surface Creek near Cedaredge, Colo. & 38.984703 & -107.854508 & 8,261 & 27 & Lower & 3 \\
\hline 09143500 & NA & Surface Creek at Cedaredge, Colo. & 38.901649 & -107.921176 & 6,220 & 39 & Lower & 3 \\
\hline 09144250 & NA & Gunnison River at Delta, Colo. & 38.753039 & -108.078403 & 4,910 & 5,628 & Lower & 3 \\
\hline 09147000 & NA & Dallas Creek near Ridgway, Colo. & 38.177768 & -107.758393 & 6,980 & 97 & Lower & 4 \\
\hline 09146200 & NA & Uncompahgre River near Ridgway, Colo. & 38.183879 & -107.745892 & 6,878 & 149 & Lower & 4 \\
\hline 09147025 & NA & Uncompahgre River below Ridgway Reservoir, Colo. & 38.240556 & -107.760306 & 6,650 & 265 & Lower & 4 \\
\hline 09147500 & NA & Uncompahgre River at Colona, Colo. & 38.331377 & -107.779504 & 6,319 & 448 & Lower & 4 \\
\hline 09149500 & NA & Uncompahgre River at Delta, Colo. & 38.741928 & -108.080903 & 4,926 & 1,115 & Lower & 4 \\
\hline 09152500 & NA & Gunnison River near Grand Junction, Colo. & 38.983316 & -108.450645 & 4,628 & 7,928 & Lower & 5 \\
\hline \multicolumn{9}{|c|}{ Natural sites } \\
\hline 09128500 & SF1 & Smith Fork near Crawford, Colo. & 38.727768 & -107.506723 & 7,095 & 43 & Lower & 3 \\
\hline 383809107384501 & RCG1 & Red Canyon at Poison Spring Gulch near Crawford, Colo. & 38.635972 & -107.645889 & 7,407 & 4.6 & Lower & 3 \\
\hline 383934107421501 & RCG2 & Red Canyon near Trail Gulch near Crawford, Colo. & 38.659411 & -107.704239 & 6,884 & 11 & Lower & 3 \\
\hline 384110108093501 & 25 Mesa & Roubideau Creek Tributary near Delta, Colo. & 38.686169 & -108.159908 & 5,170 & 0.96 & Lower & 5 \\
\hline 384545108115701 & Hwy 50 & Alkali Creek Tributary near Delta, Colo. & 38.762689 & -108.199328 & 5,000 & 9.0 & Lower & 5 \\
\hline 384633107435301 & BKKM & North Fork Gunnison Tributary near Hotchkiss, Colo. & 38.775894 & -107.731553 & 5,348 & 0.39 & Lower & 3 \\
\hline
\end{tabular}


Table 2. Periodic sampling information for the selected study sites in the Gunnison River Basin, Colorado.

[SOC, salinity as sum of consitutents in milligrams per liter; final sample size, the final number of salinity values used in the linear regression model; NA, not applicable; Ratio, ratio of salinity to specific conductance]

\begin{tabular}{|c|c|c|c|c|c|c|c|}
\hline $\begin{array}{l}\text { U.S. Geological } \\
\text { Survey } \\
\text { streamflow-gaging } \\
\text { station number, } \\
\text { figures 1-5 }\end{array}$ & $\begin{array}{l}\text { Site short } \\
\text { name, } \\
\text { figures } 1 \\
\text { and } 5\end{array}$ & U.S. Geological Survey streamflow-gaging station name & $\begin{array}{l}\text { Beginning of the study } \\
\text { period }\end{array}$ & $\begin{array}{c}\text { End of the study } \\
\text { period }\end{array}$ & $\begin{array}{c}\text { Number } \\
\text { of SOC } \\
\text { samples }\end{array}$ & $\begin{array}{c}\text { Final } \\
\text { sample } \\
\text { size }\end{array}$ & Ratio \\
\hline \multicolumn{8}{|c|}{ Salinity trend sites, water years 1989-2004 } \\
\hline 09114500 & NA & Gunnison River near Gunnison, Colo. & $10-05-1988$ & 09-08-2004 & 14 & 142 & 0.58 \\
\hline 09124500 & NA & Lake Fork at Gateview, Colo. & 10-05-1998 & 09-08-2004 & 0 & 112 & ${ }^{1} 0.58$ \\
\hline 09126000 & NA & Cimarron River near Cimarron, Colo. & $10-06-1988$ & 09-13-2004 & 0 & 48 & 0.58 \\
\hline 09128000 & NA & Gunnison River below Gunnison Tunnel, Colo. & $10-06-1988$ & 09-20-2004 & 58 & 202 & 0.59 \\
\hline 09132500 & NA & North Fork Gunnison River near Somerset, Colo. & $10-06-1988$ & 09-09-2004 & 2 & 141 & ${ }^{2} 0.64$ \\
\hline 09134000 & NA & Minnesota Creek near Paonia, Colo. & $10-06-1988$ & 09-09-2004 & 0 & 134 & ${ }^{3} 0.65$ \\
\hline 09143000 & NA & Surface Creek near Cedaredge, Colo. & $10-07-1988$ & 09-10-2004 & 0 & 123 & ${ }^{3} 0.65$ \\
\hline 09143500 & NA & Surface Creek at Cedaredge, Colo. & $10-07-1988$ & $09-10-2004$ & 0 & 128 & ${ }^{3} 0.65$ \\
\hline 09144250 & NA & Gunnison River at Delta, Colo. & $10-03-1988$ & 07-03-2004 & 26 & 168 & 0.67 \\
\hline 09147000 & NA & Dallas Creek near Ridgway, Colo. & $10-07-1988$ & 07-04-2004 & 0 & 132 & ${ }^{1} 0.65$ \\
\hline 09146200 & NA & Uncompahgre River near Ridgway, Colo. & 10-07-1988 & 09-14-2004 & 63 & 195 & 0.65 \\
\hline 09147025 & NA & Uncompahgre River below Ridgway Reservoir, Colo. & $10-07-1988$ & 09-15-2004 & 0 & 146 & ${ }^{1} 0.65$ \\
\hline 09147500 & NA & Uncompahgre River at Colona, Colo. & $10-07-1988$ & $09-15-2004$ & 31 & 173 & 0.66 \\
\hline 09149500 & NA & Uncompahgre River at Delta, Colo. & $10-04-1988$ & $09-16-2004$ & 117 & 255 & 0.72 \\
\hline 09152500 & NA & Gunnison River near Grand Junction, Colo. & $10-12-1988$ & $08-17-2004$ & 146 & 210 & 0.67 \\
\hline \multicolumn{8}{|c|}{ Salinity trend sites, water years 1989-2007 } \\
\hline 09114500 & NA & Gunnison River near Gunnison, Colo. & $10-05-1988$ & 08-13-2007 & 14 & 155 & 0.58 \\
\hline 09128000 & NA & Gunnison River below Gunnison Tunnel, Colo. & $10-06-1988$ & 08-21-2007 & 58 & 224 & 0.59 \\
\hline 09132500 & NA & North Fork Gunnison River near Somerset, Colo. & $10-06-1988$ & 09-12-2007 & 2 & 158 & ${ }^{2} 0.64$ \\
\hline 09146200 & NA & Uncompahgre River near Ridgway, Colo. & $10-07-1988$ & $07-17-2007$ & 75 & 206 & 0.65 \\
\hline 09152500 & NA & Gunnison River near Grand Junction, Colo. & $10-12-1988$ & 09-05-2007 & 165 & 251 & 0.67 \\
\hline
\end{tabular}


Table 2. Periodic sampling information for the selected study sites in the Gunnison River Basin, Colorado.—Continued

[SOC, salinity as sum of consitutents in milligrams per liter; final sample size, the final number of salinity values used in the linear regression model; NA, not applicable; Ratio, ratio of salinity to specific conductance]

\begin{tabular}{|c|c|c|c|c|c|c|c|}
\hline $\begin{array}{l}\text { U.S. Geological } \\
\text { Survey } \\
\text { streamflow-gaging } \\
\text { station number, } \\
\text { figures 1-5 }\end{array}$ & $\begin{array}{l}\text { Site short } \\
\text { name, } \\
\text { figures } 1 \\
\text { and } 5\end{array}$ & U.S. Geological Survey streamflow-gaging station name & $\begin{array}{c}\text { Beginning of the study } \\
\text { period }\end{array}$ & $\begin{array}{c}\text { End of the study } \\
\text { period }\end{array}$ & $\begin{array}{c}\text { Number } \\
\text { of SOC } \\
\text { samples }\end{array}$ & $\begin{array}{c}\text { Final } \\
\text { sample } \\
\text { size }\end{array}$ & Ratio \\
\hline \multicolumn{8}{|c|}{ Natural sites } \\
\hline 09128500 & SF1 & Smith Fork near Crawford, Colo. & 05-07-2008 & 05-15-2009 & 6 & NA & 0.60 \\
\hline 383809107384501 & RCG1 & Red Canyon at Poison Spring Gulch near Crawford, Colo. & 05-13-2008 & 06-09-2009 & 1 & NA & 0.61 \\
\hline 383934107421501 & RCG2 & Red Canyon near Trail Gulch near Crawford, Colo. & $05-15-2008$ & 06-09-2009 & 1 & NA & 0.54 \\
\hline 384110108093501 & 25 Mesa & Roubideau Creek Tributary near Delta, Colo. & 09-11-2008 & 08-10-2010 & 0 & NA & ${ }^{4} 0.54$ \\
\hline 384545108115701 & Hwy 50 & Alkali Creek Tributary near Delta, Colo. & 08-07-2008 & 08-10-2010 & 1 & NA & 0.67 \\
\hline 384633107435301 & BKKM & North Fork Gunnison Tributary near Hotchkiss, Colo. & 07-16-2008 & 07-31-2009 & 1 & NA & 0.89 \\
\hline
\end{tabular}

${ }^{1}$ The ratio used to calculate salinity from specific conductance was from the nearest site.

${ }^{2}$ The entire period of record 1977-2010 (55 SOC samples) was used to calculate the relation between salinity and specific conductance.

${ }^{3}$ The ratio used to calculate salinity from specific conductance was the basin average.

${ }^{4}$ The ratio is from a site with common geology. 
RCG2 (streamflow-gaging stations 383809107384501 and 393834107421501) are characterized by ephemeral streamflow as a result of seasonal melting of the snowpack although intermittent streamflow can occur as a result of summer thunderstorms. The three remaining sites, 25 Mesa, Hwy 50, and BKKM (streamflow-gaging stations 384110108093501, 384545108115701, and 384633107435301), are located at the lower elevations and are characterized by intermittent flow as a result of summer thunderstorms.

\section{Subbasins}

In this report, the Gunnison River Basin is divided into five subbasins to address the different land uses and geology within each subbasin (figs. 2, 3, and 5). Four of the subbasins correspond to areas upstream from each of four mainstem sites located along the Gunnison River. One subbasin comprises the Uncompahgre River Basin upstream from Delta, Colo. (table 1; figs. 1, 2, and 3). Figure 4 shows the hydrographs of these five sites located at the outflow of the subbasins.

Subbasin 1, the upstream-most subbasin, comprises the Gunnison River drainage area upstream from the Gunnison (fig. 2). The continuous monitor for subbasin 2 was located at the streamflow-gaging station Gunnison River near Gunnison, Colo. (09114500).

Subbasin 2 refers to the area above the Gunnison Tunnel including the area drained as part of subbasin 1; subbasins 1 and 2 are collectively referred to as "the Upper Gunnison River Basin" in this report (fig. 2). Subbasin 2 also includes the small basins represented by the sites Lake Fork at Gateview, Colo. (streamflow-gaging station 09124500), Cimarron River near Cimarron, Colo. (streamflow-gaging station 09126000), and additional tributaries to the Gunnison River between the town of Gunnison and the Gunnison Tunnel. The continuous monitor for subbasin 2 was located at the streamflow-gaging station Gunnison River below Gunnison Tunnel, Colo. (09128000). The Gunnison Tunnel, in subbasin 2, (fig. 1) including South Canal, delivers approximately 320,000 acre-feet of water per year from the Gunnison River to the Uncompahgre River, subbasin 4, (fig. 3) during the irrigation season (April through October) (Colorado's Decision Support Systems, 2004).

Subbasin 3 refers to the area upstream from the Gunnison River at Delta, Colo. (streamflow-gaging station 09144250) and includes areas drained as part of subbasins 1 and 2. Subbasin 3 also includes the areas represented by the sites North Fork of the Gunnison River, Colo. (streamflowgaging station 09132500), Minnesota Creek near Paonia, Colo. (streamflow-gaging station 09134000), Surface Creek near Cedaredge, Colo. (streamflow-gaging station 09143000), and Surface Creek at Cedaredge, Colo. (streamflow-gaging station 09143500). The continuous monitor for subbasin 3 was located at the streamflow-gaging station Gunnison River at Delta, Colo. (09144250).
Subbasin 4 comprises the Uncompahgre River Basin upstream from Delta and is the only subbasin that did not include a reach of the Gunnison River. Subbasin 4 is considered separately in this report because it contained the most irrigated agricultural lands (fig. 3) and large surface areas of Mancos Shale (fig. 5). The majority of the NRCS salinitycontrol projects have been implemented in this subbasin. The continuous monitor for subbasin 4 was located at the streamflow-gaging station Uncompahgre River at Delta, Colo. (09149500) where the Uncompahgre River discharges into the Gunnison River downstream from subbasin 3.

Subbasin 5 comprises the entire study area, which includes all of the previously described subbasins as well as any minor tributaries between Delta and Grand Junction. The continuous monitor for subbasin 5 was located at the streamflow-gaging station Gunnison River near Grand Junction, Colo. (09152500) (table 1, figs. 1 and 3).

\section{Data Collection and Processing}

Data were collected at 21 sites operated by the USGS and are stored on the agency's National Water Information System (http://waterdata.usgs.gov). Periodic water-quality samples were collected at all 15 salinity trend sites and all but one of the natural sites. Continuous specific-conductance data were collected at the six natural sites. Continuous streamflow data were collected at all 21 sites.

\section{Periodic Water-Quality Sampling}

Periodic water-quality sampling included measurements of selected field properties and sometimes included collection of a water sample for laboratory analysis. Field properties included specific conductance, water temperature, $\mathrm{pH}$, and alkalinity. Field properties were measured at the time of sample collection; $\mathrm{pH}$ and alkalinity were measured only when a water sample was collected for laboratory analysis. All field measurements and water-sample collection and processing were done in accordance with the USGS National Field Manual (U.S. Geological Survey, variously dated). The specific-conductance and $\mathrm{pH}$ meters were calibrated to standards that bracketed the field values and calibration data were recorded. Water samples were sent to the National Water Quality Laboratory in Denver, Colo. for analysis of major ion concentrations including calcium, chloride, fluoride, magnesium, potassium, silica, sodium and sulfate using the inductively coupled plasma method (Fishman and Friedman, 1989). Water samples were also analyzed for selenium concentrations by using collision cell inductively coupled plasma-mass spectrometry (Gabarino and others, 2006). Salinity-concentration data were determined by sum of constituents (SOC) methods or residue on evaporation at $180^{\circ}$ Celsius (ROE) methods. SOC is calculated as the sum of major ion concentrations (calcium, magnesium, sodium, potassium, silica, chloride, 
sulfate, and carbonate/bicarbonate expressed as carbonate equivalent). Additionally, other dissolved constituents such as nutrients and trace elements were included in the calculation if the sample was analyzed for those constituents and they were present in large enough quantities in the sample. Periodic water samples for laboratory analysis were collected at 8 of the 15 salinity trend sites. Measurements were limited to the field properties specific conductance and water temperature at the other seven sites.

All field and analytical data were reviewed by waterquality personnel in the USGS Colorado Water Science Center. Questionable laboratory results were referred back to the National Water Quality Laboratory for review and/ or reanalysis. Data on field properties and analytical results are stored in the USGS National Water Information System (http://waterdata.usgs.gov). Quality assurance of all of the data was accomplished using USGS-approved methods for data evaluation which included automated and manual statistical evaluations by multiple reviewers (Hem, 1985; Rantz and others, 1982; U.S. Geological Survey, variously dated; Wagner and others, 2000).

\section{Continuous Streamflow-Gaging Stations}

Continuous streamflow-gaging stations were operated for various periods at all 21 sites. The continuous streamflowgaging stations at the 15 salinity trend sites recorded stage at 15-minute intervals. The continuous streamflow-gaging stations at the six natural sites recorded specific conductance, water temperature, and stage at 15 -minute intervals.

Streamflow was estimated by using the stage recorded at 15-minute intervals at continuous streamflow-gaging stations. Stage is the height of the water surface at a location along a river and streamflow is the quantity of water passing a location along a stream. The two are related using the relation between periodic measurements of streamflow and the corresponding stage, the streamflow-stage relation (Olson and Norris, 2005). Streamflow is estimated by applying the streamflow-stage relation to the stage values recorded at 15-minute intervals at each streamflow-gaging station. Daily streamflow values were calculated by taking the mean of the 15-minute streamflow estimates for each day. The streamflow-stage relations for the streamflow-gaging stations at the salinity trend sites have been defined by measurements of streamflow over a wide range of river stages.

Daily streamflow was calculated for all days in the year for 13 of the 15 salinity trend sites; however, 2 of the sites had stage data and streamflow calculations for only a portion of each year. Beginning in 2000, the two Surface Creek streamflow-gaging stations were operated only from April through September (streamflow-gaging stations 09143000 and 09143500). Therefore, daily streamflow was calculated only for those months for all years in the study period and calculated mean values and totals of salinity concentration and load (described in the section Salinity Concentration and Load Estimation) for these two sites were only for partial years.

For all of the natural sites, periods of streamflow were identified by using the stage and specific conductance values recorded by the monitor. Streamflow was indicated by specific conductance values that were greater than zero that corresponded with increasing levels of the stage recorded by the monitor. The streamflow-stage relations for three of the natural sites (SF1, RCG1, and RCG2) were defined using measurements of streamflow taken at the time of the periodic waterquality samplings. A main assumption for the streamflow-stage relations at these sites was that the relation was linear and the intercept was zero, which meant that zero stage equated to zero streamflow. Streamflows were calculated from the streamflow-stage relations that were defined for each site.

At the three sites characterized by intermittent streamflow (BKKM, Hwy 50, and 25 Mesa), the streamflow-stage relation was developed using indirect estimates of peak streamflow after the occurrence of streamflow. High-water marks were flagged using field evidence after two streamflow occurrences at 25 Mesa and one streamflow occurrence each at BKKM and Hwy 50 (table 3). The elevations and locations of the high-water marks were then surveyed in the field, and the field surveys were used to compute streamflow indirectly using the slope-area method described by Rantz and others (1982). Manning's roughness values were estimated using techniques described in Phillips and Tadayon (2006). The calculated streamflow was then related back to the peak stage measured by the continuous monitor. The remaining stage measurements from the monitor for the period of streamflow were converted to streamflows based on the relation between the peak stage and indirectly calculated peak streamflow. However, at the Hwy 50 site, the flagged streamflow occurrence was not recorded by the monitor because of a temporary malfunction at the time of the streamflow. Therefore, a streamflow-stage relation was developed using the dimensions of the culvert and equations for open-channel hydraulics for a range of depths (Sturm, 2010). The assumption of the Hwy 50 streamflow-stage relation was that the depth in the culvert was equivalent to the stage recorded by the monitor. At both the 25 Mesa and Hwy 50 sites, one streamflow occurrence completely submerged the monitor and resulted in erroneous stage values. The peak depth of those streamflows was estimated using field evidence and the estimated peak depths were assigned to the 15-minute interval that had the largest stage value recorded on the monitor. The remaining stages recorded by the monitor that were greater than the height of the opening to the atmosphere on the monitor were estimated by fitting a hydrograph with the estimated stage associated with the peak depth and the remaining stage values that were less than the height of the opening. 
Table 3. Summary of streamflow and salinity information from monitors at the natural sites included in this study in the Gunnison River Basin, Colorado.

[ND, not determined because of lack of data]

\begin{tabular}{|c|c|c|c|c|c|}
\hline $\begin{array}{c}\text { Short } \\
\text { name, } \\
\text { figures } 1 \\
\text { and } 5\end{array}$ & Dominant geology & Streamflow date & $\begin{array}{l}\text { Salinity load, } \\
\text { in tons }\end{array}$ & $\begin{array}{l}\text { Streamflow } \\
\text { duration, } \\
\text { in days }\end{array}$ & $\begin{array}{c}\text { Peak } \\
\text { streamflow, } \\
\text { in cubic feet } \\
\text { per second }\end{array}$ \\
\hline \multicolumn{6}{|c|}{2008} \\
\hline BKKM & Mancos Shale & 08-06-2008 & 27.9 & 0.05 & 34.56 \\
\hline RCG1 & Sandstone & ND to $05-25-2008$ & ${ }^{1} 4.93$ & ${ }^{1} 12.3$ & ${ }^{1} 2.33$ \\
\hline RCG2 & Sandstone & ND to $05-20-2008$ & ${ }^{1} 0.14$ & ${ }^{1} 5.1$ & ${ }^{1} 0.19$ \\
\hline SF1 & Crystalline & $05-14-2008$ to $05-14-2009$ & 3,080 & 365 & 2,927 \\
\hline \multicolumn{6}{|c|}{2009} \\
\hline 25 Mesa & Sandstone & 06-02-2009 & 2.88 & 1.3 & 20.8 \\
\hline 25 Mesa & Sandstone & $06-25-2009$ & 0.25 & 0.18 & 222.2 \\
\hline 25 Mesa & Sandstone & 09-18-2009 & 0.46 & 0.26 & 7.0 \\
\hline 25 Mesa & Sandstone & 09-20-2009 & 0.28 & 0.26 & ${ }^{2} 15.3$ \\
\hline Hwy 50 & Mancos Shale & $08-25-2009$ & 0.01 & 0.10 & 0.4 \\
\hline Hwy 50 & Mancos Shale & 09-ND-2009 & ND & ND & 231.3 \\
\hline \multicolumn{6}{|c|}{2010} \\
\hline 25 Mesa & Sandstone & 07-30-2010 & 0.42 & 0.27 & 7.7 \\
\hline 25 Mesa & Sandstone & 08-04-2010 & 7.16 & 0.35 & 600 \\
\hline Hwy 50 & Mancos Shale & 07-28-2010 & 54.1 & 0.17 & 420 \\
\hline Hwy 50 & Mancos Shale & 08-04-2010 & 0.03 & 0.08 & 0.4 \\
\hline
\end{tabular}

\section{Salinity Concentration and Load Estimation}

In this report, salinity is discussed in terms of both concentration (milligrams per liter) and load (tons). Salinityconcentration data were from either periodic water-quality samples, as described in the Periodic Water-Quality Sampling section of this report, or from surrogate data, as described in this section (subsection labeled Surrogate Data). Instream salinity load, in tons, is computed by multiplying the salinity concentration (milligrams per liter) by the streamflow (cubic feet per second), and a unit conversion constant (0.002697). Throughout the report, sites are compared based on estimates of annual salinity loads and mean annual salinity concentrations. Regression modeling, detailed in this section (subsection labeled Regression Modeling), was used to estimate daily loads. To obtain annual loads, the daily loads were summed by water year. Concentrations were computed by dividing the load by streamflow and the unit conversion constant. The mean annual concentration is the average, by year, of the daily concentrations computed from the daily estimate of salinity load.

\section{Surrogate Data}

A predictive relation between specific conductance and salinity was developed to estimate salinity for all samples when only specific-conductance data were available. The ability to estimate salinity from specific-conductance data was needed because salinity data at all 21 sites was much less numerous than available specific-conductance data. The dataset used for regression modeling, detailed in the Regression Modeling subsection of this report, included both observed and estimated salinity concentrations.

Salinity concentrations (SOC or ROE) were reported as part of the periodic water-quality sampling for seven of the salinity trend sites. At least 14 periodic salinity samples were collected at each of these sites in conjunction with measurements of specific conductance values (table 2). One water sample was collected at each of four of the natural sites for the determination of both salinity and specific conductance. Six water samples were collected at SF1 for the determination of both salinity and specific conductance. No salinity determinations were made for the 25 Mesa site. All 21 sites 
had additional specific-conductance data that were used as a surrogate for estimates of salinity concentrations.

At the 7 salinity trend sites with 14 or more periodic salinity samples during the study period, a simple linear regression was calculated with specific conductance as the explanatory variable and salinity concentration as the response variable using the data from the study period (regression properties are provided in table 7 of the Appendix). The linear regression was specific to the individual site and the study period analyzed. The linear regressions were used to calculate salinity concentrations from the specific-conductance data when no corresponding measured salinity data were available. In order to reduce bias, measured specific-conductance values that were outside the range of the linear regression were not used to calculate salinity concentrations. For example, 14 periodic water samples collected during 1989-2004 at Gunnison River at Gunnison, Colo. (streamflow-gaging station 09114500) included salinity-concentration and specificconductance data. The specific-conductance values in the 14 samples used to develop the linear regression ranged from 137 to 232 microsiemens per centimeter. Additionally, 243 other samples included only measured specific-conductance values. The range of the 243 additional samples was 139 to 380 microsiemens per centimeter. As such, a total of 53 of the samples with only specific-conductance data fell outside the range of 137 to 232 . These 53 values were not used to calculate salinity values and the final record of periodic salinity data for this site included 204 values (14 measured concentrations and 190 estimated concentrations).

For some sites, removal of specific-conductance values that were outside the range of the linear regression resulted in the loss of a portion of the high-flow sample values from some of the datasets used for analysis. For all but one site, at least one other high-flow sample within the specific-conductance range was available for the same year and included in the dataset. For the site used in the example, Gunnison River near Gunnison, Colo. (streamflow-gaging station 09114500), removal of specific-conductance values outside the range resulted in the removal of all high-flow samples for WY 2002. Generally, high-flow samples were associated with low specific conductance and the removal of those samples would result in higher estimates of salinity load from the model. In the example, the samples that were removed had high specific conductance which would result in lower estimates of salinity load from the model.

For one site, North Fork of the Gunnison River, Colo. (streamflow-gaging station 09132500), data for only two salinity samples were available for the study period. As such, the linear regression was developed using 55 samples that included salinity concentrations collected during the period of record for the site (October 1977 through February 2010). This site also was one of the five sites where data were analyzed for trends for two study periods. The linear regression developed for this site was the same for both study periods. After estimating surrogate salinity concentrations, the final dataset included
141 salinity concentrations for the period 1989-2004 and 158 salinity concentrations for the period 1989-2007.

To estimate salinity concentrations at the remaining seven salinity trend sites where only specific-conductance data were available, a different approach was used because linear regressions that were developed were site specific. Using the samples from the seven salinity trend sites with 14 or more periodic salinity samples collected during the study period, a ratio was calculated using equation 1 (Hem, 1985) that related specific conductance to salinity concentration.

$$
S C(a)=S O C
$$

where

$S C$ is specific conductance, in microsiemens per centimeter at 25 degrees Celsius,

$a$ is ratio of salinity to specific conductance, and

$S O C$ is salinity as sum of constituents, in milligrams per liter.

The ratios of each sample were averaged by site and study period and salinity values for the seven sites with only specificconductance data were calculated by multiplying specific conductance by the average ratio for either the nearest site or the basin average. Table 2 lists the ratio that corresponds to each site. For the sites that had both salinity and specific conductance data, the ratio was calculated for the samples from that site. For the other 7 sites, the ratio listed is the one used to calculate salinity data from the existing specific conductance data. Table 7 of the appendix details the properties of the single linear regression that was calculated for the 8 sites that had both salinity and specific conductance data. The calculated ratios for those sites are also listed in that table to provide a comparison between the two methods of estimating salinity from specific conductance.

The ratios also were used to compare the two regressions developed for each of the five sites that had sufficient data to analyze both study periods (table 2). For three of the five sites (streamflow-gaging stations 09114500, 09128000, and 09132500), the linear regressions for the two study periods used the same data so the respective average ratios were the same for the two study periods, and therefore had the same average ratio. The site located on the Uncompahgre River near Ridgway, Colo. (streamflow-gaging station 09146200) had additional data collected after WY 2004 so linear regressions were developed separately for the study periods. The means of the ratios calculated from the results were both 0.65 which indicated that the relation between specific conductance and salinity concentration did not change with the additional data (table 2). Linear regressions were developed separately for the fifth site, the Gunnison River near Grand Junction, Colo. (streamflow-gaging station 09152500). The means of the ratios calculated from the results were both 0.67 which indicated that the relation between specific conductance and salinity concentration did not change with the additional data (table 2). 
Specific-conductance data were used as a surrogate for salinity data for the natural sites as well. At the Hwy 50 site, one periodic water-quality sample was collected and the ratio of salinity to specific conductance was calculated from that sample (table 2). No water-quality sample was collected at the 25 Mesa site, so the ratio from RCG2 was used to calculate salinity from specific conductance. RCG2 was chosen because the two sites are underlain by similar geology. Loads for the natural sites were estimated using calculated salinity data and streamflow calculated from stage data recorded at 15-minute intervals by the monitor. Loads were summed for each period of streamflow and annually.

Annual yields for the natural sites, in tons of salt per square mile (ton $/ \mathrm{mi}^{2}$ ), were calculated by dividing the annual load by the drainage area of the site. The annual yields were associated with the geology of the drainage area of each site and extrapolated to the entire basin to estimate the natural component of salinity load for the study area. Two sites represented drainages of Mancos Shale geology; three sites represented drainages of sandstone geology; and one site represented a drainage dominated by crystalline geology (table 3). The site representing a drainage dominated by crystalline geology, Smith Fork near Crawford, SF1, (streamflow-gaging station 09128500) has the largest drainage area of the six natural sites and 35 percent of the area is underlain by Mancos Shale (Tweto, 1979; Green, 1992). However, the Mancos Shale is heavily weathered in this area and was assumed to contribute nonsubstantial amounts of salinity to the water in the Smith Fork at this location. Specific conductance and salinity values measured at this site were at least 10 times smaller than those measured at the two sites that represented Mancos Shale geology. This is consistent with the assumption that the Mancos Shale in the SF1 drainage does not contribute substantial amounts of salinity. Thirty-five percent of the area of the largest natural basin is underlain by Mancos Shale so the SF 1 yield is presented as 65 percent of the original calculation, where the 65 percent value is a conservative estimation for crystalline yield.

\section{Regression Modeling}

Daily constituent loads, including salinity, were estimated using daily streamflow values and decimal time as explanatory variables (Ferguson, 1986; Cohn and others, 1989 and 1992; and Crawford, 1996). LOADEST (LOAD ESTimation), a USGS statistical program developed by Runkel and others (2004), can build linear regression models relating load to streamflow, time, and season. S-LOADEST, a version of the LOADEST software developed as a "plug-in" to the PC-based statistical software package Spotfire S+ (TIBCO Software, Inc., 1998-2008), was used in this study. S-LOADEST uses up to 10 explanatory variables to build a linear regression model that defines the relation of a constituent load to streamflow, time, and season. The regression model takes the general form (equation 2):

$$
\begin{aligned}
\ln \hat{L}=b_{o} & +b_{1}\left(\ln Q-\ln Q^{*}\right)+b_{2}\left(\ln Q-\ln Q^{*}\right)^{2}+b_{3}\left(t-t^{*}\right) \\
& +b_{4}\left(t-t^{*}\right)^{2}+b_{5} \sin (k 2 \pi T)+b_{6} \cos (k 2 \pi T)+\varepsilon
\end{aligned}
$$

where

$\hat{L}$ is estimated salinity load, in tons per day;

$b_{o}$ is regression equation intercept;

$b_{n} \quad$ is coefficient on the $\mathrm{nth}$ regression variable;

$Q \quad$ is daily streamflow, in cubic feet per second;

$Q^{*} \quad$ is streamflow centering value from the calibration data set, in cubic feet per second;

$t$ is time, in decimal years;

$t^{*} \quad$ is time centering value from the calibration data set, in decimal years;

$k \quad$ is an integer;

$T \quad$ is seasonality term representing the decimal portion of the year starting January 1 ;

and

$\varepsilon \quad$ is error associated with the regression equation.

The model is developed using a calibration dataset that includes the periodic sample collection date, the associated value of salinity concentration, and the daily streamflow associated with the sampling date from the continuous dataset. The input values for concentration and streamflow were $\log$ transformed to meet the assumptions of normality and constant variance (Hirsch and others, 1991). In some of the final selected model equations, quadratic terms for decimal time and/or streamflow were significant variables (regression properties are available in table 8 of the Appendix). However, the possibility of multicollinearity increases when both the linear and quadratic terms for decimal time and/or streamflow are in the regression equation thus inflating the variance in the associated coefficients. Streamflow and decimal time were centered to prevent multicollinearity and to ensure orthogonality among predictor variables (Cohn and others, 1992). When the quadratic term was significant in the model, the linear term also was included even if it was not significant. The sine and cosine terms, seasonal terms, were included to address seasonal differences (Cohn and others, 1992). Both variables (sine and cosine) are required to account for the amplitude, or magnitude, and the day of the peak, even if one of the pair is not significant (Cohn and others, 1992). Additional seasonal terms account for the possibility of two and/or three annual cycles (in equation 2: $k=2$ or 3 ). Model coefficients $\left(b_{n}\right)$ were estimated using adjusted maximum likelihood estimation (Runkel and others, 2004) and the final load estimate applies a bias correction factor to address retransformation bias (Finney, 1941; Likes, 1980; Runkel and others, 2004). The assumptions of regression require that the model residuals are normally distributed and homoscedastic (have equal variance).

Parametric methods, such as the linear model determined by S-LOADEST, assume a normal distribution of the data while nonparametric techniques do not require the data to be normally distributed (Helsel and Hirsch, 2002). Where there is a perfect normal distribution of the data, parametric tests 
have more statistical power. However, water-quality data will only approximate a normal distribution and so the statistical power in parametric and nonparametric techniques is similar for analysis of water-quality data (Helsel and Hirsch, 2002). Statistical power, in this analysis, refers to the probability of rejecting the null hypothesis that there is no time trend when there is a net trend (Alley, 1988; Hirsch and others, 1991). The p-value associated with each model coefficient is the probability of obtaining the computed parameter coefficient when the null hypothesis is true; where the null hypothesis is that the coefficient is zero. The following criteria were used to determine significance: $p \leq 0.01$, highly significant; $0.01<p \leq 0.05$, significant; $0.05<p \leq 0.1$, marginally significant; and $p>0.10$, not significant.

The final S-LOADEST model equations were obtained through an iterative process. The first step used the software option to choose the "best" model from nine model options made up of varying combinations of the variables listed in equation 2. The "best" model was the model with the lowest value of the Akaike Information Criteria statistic (Runkel and others, 2004). Variables then were added or removed to the "best" model based on the significance of the coefficient and statistical diagnostics that indicated normally distributed model residuals. Significance of the coefficient was based on the significance criteria detailed in the previous paragraph. S-LOADEST produced diagnostic plots which included normal-probability plots and standardized residuals plots. Normality of model residuals was indicated when the quantiles plot were somewhat linear relative to a 1:1 line and the plots of the residuals had no pattern and indicated uniformity of scatter (homoscedacity). The plots were assessed qualitatively by the author. A plot of the standardized residuals against the season of the year was used to determine the need for additional seasonal terms. Seasonal terms (where $\mathrm{k}=2$ or 3 in equation 2) were added or removed to the regression equations to reduce the occurrence of sinusoidal patterns observed in the residual plots. The final model was selected based on the qualitative assessment of the diagnostic plots.

Additional parameters examined for final model selection included the $\mathrm{R}^{2}$ of the model, serial correlation of the residuals (less than 0.6), and estimated residual variance (less than $0.1)$. The $\mathrm{R}^{2}$ value indicates the percentage of the variability that can be explained by the model; for example, a value of 72 indicates that 72 percent of the variability is explained by the model. Serial correlation refers to correlation that results from time-series data and would be indicated by a pattern in the residuals. The value is presented as a proportion and can be interpreted somewhat like the $\mathrm{R}^{2}$ in that a value of 0.6 indicates that 60 percent of the variability in the residuals can be explained by time while a value of 0 indicates that there is no pattern. The serial correlation of the residuals indicates whether the model violates the assumption that error terms are independent, or uncorrelated. Finally, residual variance is unexplained error in the model and the value indicates how well the model line fits the calibration dataset. Residual variance is calculated by the sum of squares of the residuals. Small residual variance values indicate more accurate predictions.

Daily salinity loads were estimated using a selected form of equation 2 that was unique for each site. The estimation dataset contained daily streamflow values, dates, and additional seasonality terms (where $\mathrm{k}=2$ or 3 in equation 2). Daily salinity concentrations were calculated by dividing the estimate of daily load by the streamflow and the unit conversion constant. Annual loads were obtained by summing the daily loads for each water year. Annual salinity concentrations are the average of the daily concentrations for each water year.

To aid in interpretation of the data, plots of the residuals from a modified model equation were analyzed modified residuals. Modified residuals were calculated using the regression model with only streamflow and seasonality as the explanatory variables; time and/or quadratic time were removed from the regression model if they were significant. The modified residuals were plotted against decimal time, and a resistant center line was fit to the data using locally-weighted scatterplot smoothing (LOWESS) procedures (Cleveland and McGill, 1984; Cleveland, 1985). The resistant center line aided in the observation and interpretation of patterns without being strongly influenced by outliers (Helsel and Hirsch, 2002). This approach is similar to the one used by Butler (1996).

\section{Salinity Trend Testing}

Trends in annual salinity concentrations caused by human or natural factors may be masked by variability in streamflow between water years because of the correlation between salinity concentration and streamflow. The correlation can be positive, negative, or both (parabolic). In streams and rivers where point sources of salinity or groundwater discharge dominate, salinity inputs enter the stream at a constant rate as streamflow changes over time. As a result, increased streamflow would dilute salinity concentrations and the correlation would indicate a negative trend. In systems where erosion and sediment transport processes dominate, a substantial rainfall event might lead to the transport of large amounts of surface sediments that would carry additional salt to the stream or river. In this case, increased streamflow would result in increased salinity and a potential positive correlation in the trend (Smith and others, 1982; Hirsch and others, 1991). In the Gunnison River Basin, the main source of salinity is the near-surface geology. In many areas of the basin, irrigated agriculture has resulted in increased deep percolation that has led to increased streamflow and increased salinity concentrations (Prairie and others, 2005; Kanzer and Merritt, 2008; Kenney and others, 2009). Irrigated agriculture also may flood the surface soils and create overland flow that would deliver sediment and attached salts to the rivers and streams.

In order to determine trends in salinity concentration and load, the effects of streamflow variability on salinity concentration and load over the study periods needed to be removed. 
When streamflow variability is removed, a downward trend in salinity concentration would indicate that less salt is leaching into the water for a given streamflow. The major effects of wet years and dry years are removed and a significant trend in salinity concentration is attributable to something other than changes in climate, precipitation, or streamflow. However, climatic factors may still affect streamflow and, to a lesser degree, salinity concentrations. For example, a wet year might result in a flushing of salt and the variability due to streamflow would be accounted for with an average streamflow condition. If the wet year were followed by a series of average streamflow years, the effect of flushing the salts in the wet year would likely still be observable in the subsequent average years as lower-than-average salinity concentrations. An averaged streamflow condition would not account for this variability in streamflow (Anning and others, 2007). After streamflow variability is removed, a significant trend in salinity concentration and load would indicate a change in the processes that cause salt to enter the stream. The processes discussed in this report were generally changes in irrigation practices, urbanization, and land cover.

Many of the previous studies that have reported on salinity loads and trends in the Gunnison River Basin have used a two-step methodology for trend analysis, referred to in this report as regression on residuals (Liebermann and others, 1987 and 1989; Butler, 1996; Leib and Bauch, 2008). The method used in this report, normalized regression, uses one step to test for a time trend in salinity. The main difference between the two methods is how they address the variability in salinity resulting from the variation in streamflow within the trend test. The regression on residuals method was compared to the normalized regression method to provide a basis for comparing trends addressed in this report to those from previous studies. The comparison used data from Gunnison River near Grand Junction, Colo. (streamflow-gaging station 09152500) for 3 comparison periods: WY 1989-2004; 1989-2007; and 1986-2003. This site was chosen because it is one of the sites for which loads were calculated and trends were tested in previous studies (Liebermann and others, 1989; Butler, 1996; Leib and Bauch, 2008) and because more data were available for this site than for other sites in the study area.

\section{Regression on Residuals Method}

Daily salinity concentration and load were estimated using the selected form of model equation 2 determined using the S-LOADEST software as detailed in the Salinity Concentration and Load Estimation section of this report. The estimation dataset included daily streamflow from the continuous dataset. The output included daily estimations of salinity load which, subsequently, were summed for each water year to obtain an estimated annual salinity load. Estimated annual salinity loads were calculated using the daily streamflow value reported from the continuous streamflow-gaging stations so, at this step, the variability because of streamflow had not been removed. These estimated loads were a close approximation of what actually occurred at the streamflow-gaging site where the measurements were made. They were reported with the trend results to put the trend results into context.

The adjustment for streamflow occurred in a second step and the term 'regression on residuals' refers specifically to this second step. To calculate the residuals, estimated annual salinity loads were first regressed against a transformation of streamflow (Smith and others, 1982). Among the streamflow transformations tested, the hyperbolic function in equation 3 resulted in the best fit for the reported data:

$$
f(Q)=\frac{1}{1+(\beta Q)}
$$

where

$$
\begin{aligned}
f(Q) & \text { is hyperbolic functional form of discharge; } \\
Q & \text { is streamflow, in acre-feet per year; }
\end{aligned}
$$

and
$\beta$ is a constant, 0.000001 for the application in this study.

The residuals of the regression of hyperbolically-transformed streamflow on annual salinity load are referred to as "annual flow-adjusted salinity loads." The annual flow-adjusted salinity loads for the Gunnison River at Grand Junction site were regressed against water year to test for a trend over time. Nonparametric methods, such as the Kendall test (Kendall, 1975), were used in previous studies to test for trends in the annual flow-adjusted salinity loads when the assumptions of normality and constant variance were not met. The parametric test (linear regression) was chosen for this dataset because the assumptions of normality were met for the model and the normalized regression method (Normalized Regression Method section of this report) is a parametric method. The significance of the time trend was indicated by the p-value associated with the slope of the linear regression, where the slope was the coefficient on the water-year term ( $m$ in equation 4 ). The slope was equal to the mean annual change in salinity load, in tons. To determine the study period trend, the slope was multiplied by the number of years in the study period. The direction of the time trend was indicated by the sign on the slope; a negative slope indicated a downward trend. The percent change was calculated relative to the estimated mean annual salinity load for the study period. The upper and lower 95 -percent confidence intervals were calculated using equation 4 :

$$
95 \% C I=\left\{m \pm\left(1.96 * S E_{m}\right)\right\} *\left(t_{2}-t_{1}\right)
$$

where

$95 \%$ CI is 95-percent confidence interval on the mean annual change in salinity load;

$m$ is coefficient associated with the water-year term (slope of the linear regression);

$S E_{m}$ is standard error associated with $m$; 
$t_{2}$ is ending date of the study period, in decimal time;

and

$t_{1}$ is beginning date of the study period, in decimal time.

\section{Normalized Regression Method}

As in the initial steps of the regression on residuals method, salinity concentration and load for the normalized regression method were estimated using the selected form of model equation 2 determined using the S-LOADEST software as detailed in the Salinity Concentration and Load Estimation section of this report. In the normalized regression method, however, the streamflow value used in the calibration and estimation datasets was an average daily streamflow condition (mean daily streamflow) for WY 1989-2009. The mean daily streamflow was calculated by taking the mean of the daily streamflow values from the continuous dataset for each day of the year for WY 1989-2009. The reader is reminded that the regression on residuals method used daily streamflow in the calibration and estimation datasets (mean of the 15-minute streamflow estimates for each day). By choosing a longer period to determine the mean daily streamflows, the average streamflow condition included a larger range of streamflow variability. Water year 1989 was chosen as the beginning year because continuous streamflow monitoring was not initiated until October 1, 1988 at one site (streamflow-gaging station 09147025) and using the same period of record for all sites ensured comparability among sites. The average daily streamflow means that, for example March 23, the streamflow value in the estimation dataset was the mean of the daily streamflow values on March 23 from 1989 through 2009. In the example, the streamflow value used for March 23 was the same for every year provided in the estimation dataset. The same mean daily streamflow was used in the trend tests for both study periods tested.

The model output included estimations of daily salinity loads that were based on an average streamflow condition for WY 1989-2009. In this report, the concentration and load that were calculated using the mean daily streamflow are referred to as "flow-normalized concentration and load." Normalizing the results with the average streamflow condition removed the variability in salinity resulting from variation in streamflow within the multiple regression, thus eliminating the need for additional steps. The model used mean daily streamflow both to explain changes in salinity load and to calculate salinity load. As a result, a trend in flow-normalized salinity load really was a trend in flow-normalized concentration. Using the approach of normalizing by streamflow, the trends at each site can be compared to one another, spatial distribution of salinity increases or decreases can be identified, and loads were cumulative downstream. Another advantage of estimating flownormalized concentrations was that it allowed for a comparison of salinity concentration between sites without having to compare streamflow between sites simultaneously. The daily flow-normalized salinity load estimates were summed for each water year to obtain an annual estimate of flownormalized salinity load.

When quadratic time was not significant in the model, the significance of the time trend was indicated by the p-value associated with the coefficient on the time term $\left(b_{3}\right.$ in equation 2 ). The sign on the coefficient indicated the direction of the trend and the coefficient was used to calculate the magnitude of the trend. Annual percent change was calculated using equation 5 and is described in Hirsch and others (1991) and Helsel and Hirsch (2002):

$$
\tau_{1}=\left(e^{b_{3}}-1\right) * 100
$$

where

$\tau_{1}=$ estimated annual trend in salinity load (only the linear-time term is significant), in percent;

$e=$ the base of the natural logarithm, 2.71828;

and

$b_{3}=$ the coefficient on the time term in equation 2. To obtain the percent change for the entire study period, the annual percent change was multiplied by the number of years in the study period: 16 years for the 1989-2004 study period and 19 years for the 1989-2007 study period. To determine the net change in salinity load, the percent change was multiplied by the annual flow-normalized load from WY 1989.

When quadratic time was significant in the final model, the magnitude and the significance of the time trend depended on both the linear and quadratic coefficients $\left(b_{3}\right.$ and $b_{4}$ in equation 2). The estimated annual trend (magnitude) was calculated using equation 6 (G. Schwarz, U.S. Geological Survey, written commun., 2011):

$$
\tau_{2}=100\left\{b_{3}+\left(2 b_{4}\left(t_{m}-t^{*}\right)\right)\right\}
$$

where

$\tau_{2}=$ estimated annual trend in salinity load (quadratictime term is significant), in percent;

$b_{4}=$ estimated coefficient on the quadratic-time term (see equation 2);

$t_{m} \quad=$ midpoint of the trend period, in decimal time (equal to $\left.\left(t_{2}-t_{1}\right) / 2\right)$;

and

$t^{*}=$ time centering value from the calibration data set, in decimal time (see equation 2).

To obtain the percent change for the entire study period, the annual percent change was multiplied by the number of years in the study period. To determine the net change in salinity load, the percent change was multiplied by the annual flownormalized load from WY 1989. The standard error of the trend estimate is calculated using equation 7 : 


$$
S E_{\tau}=100 \sqrt{V_{b_{3}}+4\left(t_{m}-t^{*}\right) \operatorname{Cov}_{\left(b_{3}, b_{4}\right)}+4\left(t_{m}-t^{*}\right) V_{b_{4}}}
$$

where

$S E_{\tau}=$ standard error of the trend estimate, in percent;

$V_{b_{3}}=$ variance of the estimated coefficient on the linear-time term;

$\operatorname{Cov}_{\left(b_{3}, b_{4}\right)}=$ ovariance between the estimated coefficients on the linear- and quadratic-time terms;

and

$V_{b_{4}} \quad=$ variance of the estimated coefficient on the quadratic-time term.

The $\mathrm{p}$-value for the trend is given by the test statistic, $\tau_{2} / S E_{\tau}$, evaluated in a t-distribution with degrees of freedom given by the difference between the number of observations used to estimate the model and the number of model coefficients (G. Schwarz, U.S. Geological Survey, commun., 2011). The upper and lower 95-percent confidence intervals (95-percent $\mathrm{CI})$ were calculated using the standard error of the trend estimate and equation 4, where $m$ was replaced by $\tau$ from equations 5 and 6 . The 95 -percent $\mathrm{CI}$ referred to the range within which the mean net change estimated by the model was expected to fall with 95-percent confidence. The confidence interval only considered the error within the S-LOADEST model and did not include the error in the calculation of salinity data using specific-conductance data. That error was not quantified for this report. When the quadratic-time term in equation 2 was significant, the trend line was parabolic, and the presentation of results includes a qualitative interpretation of the shape of the parabola and plot of modified residuals (described in the Regression Modeling section) with a LOWESS smooth line. The interpretation included an estimation of the minimum or maximum year, based on the year of the change in slope, and the direction and magnitude of the trend before and after the minimum or maximum. The magnitude was estimated based on the difference between the beginning and ending year and the year that the slope changed relative to the beginning or ending year. For example, if the maximum year was 1997, the percent change between 1989 and 1997 was relative to the load estimated in 1989 and the difference would indicate an increase from 1989 to 1997.

\section{Salinity in the Gunnison River Basin}

Salinity concentration and load from 21 sites in the Gunnison River Basin were analyzed in terms of trends and to identify sources. Trends in salinity loads were analyzed during the period WY 1989 through WY 2004 (1989-2004) for 15 selected streamflow-gaging stations and during the period WY 1989 through WY 2007 (1989-2007) for 5 of the 15 sites. Trend results are discussed in terms of irrigated land, change in land cover, urbanization, and salinity-control projects. Attempts were made to quantify the contribution of salinity within the context of the trend results from potential sources, including residential development (urbanization), changes in land cover, and natural sources. Trend results and salinity loads estimated from trend tests also were compared to USBR and NRCS estimates of off-farm and on-farm salinity reduction from salinity-control projects in the basin.

\section{Trend Analysis Method Comparison}

The regression on residuals and normalized regression methods use the same general processes in the S-LOADEST interface to estimate salinity concentration and load. Three comparisons were made to comprehensively discuss the differences between the results from the two methods. All three comparisons used data from the Gunnison River near Grand Junction, Colo. (streamflow-gaging station 09152500). The first comparison was for the 1989-2004 study period. The second comparison is for the 1989-2007 study period and is considered because the regression model includes the quadratictime term while the 1989-2004 study period does not. The third comparison is for the 1986-2003 study period presented in Leib and Bauch (2008). The S-LOADEST multiple-regression equation is the same for the two methods for each study period because the calibration datasets are the same. However, the estimates of annual load are not comparable because the estimation datasets differ; the streamflow value in the normalized regression method is the mean daily streamflow. For the regression on residuals method, the estimations of load are further analyzed and tested for a time trend. In the normalized regression method, the model development is the only step. For the remainder of the report, estimated mean annual salinity load, which is estimated using daily streamflow, is reported for each study period while flow-normalized results, estimated using the mean daily streamflow, are presented only to discuss the trend-test results. The methods are best compared by evaluating the results of each trend test.

\section{Comparison Period: 1989-2004}

The final model equation for the 1989-2004 study period was (equation 8):

$$
\text { 1n } \begin{aligned}
\hat{L} & =8.05-0.45\left(\ln Q-\ln Q^{*}\right)-0.01\left(t-t^{*}\right) \\
& -0.21(\sin (2 \pi T))-0.03(\cos (2 \pi T)) \\
& +0.12(\sin (4 \pi T))-0.05(\cos (4 \pi T))+\varepsilon
\end{aligned}
$$

From the beginning steps of the regression on residuals method in which daily streamflow is used to estimate loads, the estimated mean annual salinity load at the Gunnison River near Grand Junction site during 1989-2004 was 1,031,000 tons (table 4). The estimated mean annual concentration estimated by the model was $603 \mathrm{mg} / \mathrm{L}$. Using the normalized regression method, the mean annual flow-normalized salinity load was $1,082,000$ tons and mean annual flow-normalized concentration was $537 \mathrm{mg} / \mathrm{L}$. However, concentration and load estimates using the two methods are not comparable as the streamflow 
Table 4. Summary of results from the trend-analysis method comparisons for station Gunnison River near Grand Junction, Colorado.

[NP, not published; Estimated mean annual salinity load for the normalized regression method is flow-normalized]

\begin{tabular}{|c|c|c|c|c|c|c|}
\hline Method & $\begin{array}{l}\text { Estimated } \\
\text { mean annual } \\
\text { salinity load, } \\
\quad \text { in tons }\end{array}$ & $\begin{array}{l}\text { Estimated mean } \\
\text { annual salinity } \\
\text { concentration, in } \\
\text { milligrams per liter }\end{array}$ & $\begin{array}{l}\text { Net change in } \\
\text { salinity load, } \\
\text { in percent }\end{array}$ & $\begin{array}{l}\text { Net change } \\
\text { in salinity } \\
\text { load, in tons }\end{array}$ & $\begin{array}{c}\text { Lower } \\
\text { 95-percent } \\
\text { confidence } \\
\text { level for net } \\
\text { change in } \\
\text { load, in tons }\end{array}$ & $\begin{array}{c}\text { Upper } \\
\text { 95-percent } \\
\text { confidence } \\
\text { level for net } \\
\text { change in } \\
\text { load, in tons }\end{array}$ \\
\hline \multicolumn{7}{|c|}{ Water years 1989-2004 } \\
\hline Regression on residuals & $1,031,000$ & 603 & -16 & $-164,000$ & $-198,000$ & $-129,000$ \\
\hline Normalized regression & $1,082,000$ & 537 & -21 & $-247,000$ & $-252,000$ & $-241,000$ \\
\hline \multicolumn{7}{|c|}{ Water years 1989-2007 } \\
\hline Regression on residuals & $1,039,000$ & 599 & -15 & $-153,000$ & $-199,000$ & $-108,000$ \\
\hline Normalized regression & $1,100,000$ & 544 & -17 & $-207,000$ & $-212,000$ & $-202,000$ \\
\hline \multicolumn{7}{|c|}{ Water years 1986-2003 } \\
\hline Regression on residuals ${ }^{1}$ & $1,761,000$ & 512 & -18 & $-202,000$ & $\mathrm{NP}$ & $\mathrm{NP}$ \\
\hline Normalized regression & $1,217,000$ & 584 & -23 & $-273,000$ & $-278,000$ & $-268,000$ \\
\hline
\end{tabular}

${ }^{1}$ Leib and Bauch (2008)

values used for estimation are different. The methods are best compared using the calculated magnitude of the trend.

For the regression on residuals method, the trend magnitude was equivalent to the slope of the linear regression of water year against annual flow-adjusted loads. The slope was $-10,232$ tons of change in salinity load per year; $p$-value was less than 0.001 . The percent change, calculated by dividing the slope by the mean annual load, was -0.99 percent per year, which is equivalent to a net decrease of 16 percent over 16 years. The 95 -percent $\mathrm{CI}$ ranged from -13 percent to -19 percent. In terms of salinity load (coefficient multiplied by 16 years), the overall change was a net decrease of 164,000 tons with a 95 -percent $\mathrm{CI}$ that ranged from $-129,000$ to $-198,000$ tons (table 4 ).

In the normalized regression method, the variability of streamflow is addressed by using the mean daily streamflows to estimate load so the direction and magnitude of the time trend are a function of the coefficient on the time term in equation 8 , and the significance of the time trend is based on the $\mathrm{p}$-value associated with the coefficient on the time term. The p-value was less than 0.001 , which indicated a highly significant time trend. Annual percent change in flow-normalized salinity loads was a significant decrease of 1.3 percent which was a net decrease of 21 percent over 16 years. The net change in flow-normalized load using the normalized regression method was between $-241,000$ and $-252,000$ tons (95-percent CI) and the mean net decrease was 247,000 tons (table 4). Based on this comparison, the estimated change in salinity load is smaller using the regression on residuals method relative to the normalized regression method.

\section{Comparison Period: 1989-2007}

The final model equation for the 1989-2007 period included quadratic streamflow and quadratic time (equation 9):

$$
\text { 1n } \begin{aligned}
\hat{L} & =8.05-0.45\left(\ln Q-\ln Q^{*}\right) \\
& -0.04\left(\ln Q-\ln Q^{*}\right)-0.01\left(t-t^{*}\right) \\
& +0.001\left(t-t^{*}\right)^{2}-0.22(\sin (2 \pi T)) \\
& -0.03(\cos (2 \pi T))+0.03(\sin (6 \pi T))
\end{aligned}
$$

The estimated mean annual salinity load from the regression on residuals method during WY 1989-2007 was 1,039,000 tons and the estimated mean annual concentration was $599 \mathrm{mg} / \mathrm{L}$ (table 4). The estimated mean annual flow-normalized salinity load was $1,100,000$ tons and the estimated mean annual flow-normalized concentration was $544 \mathrm{mg} / \mathrm{L}$. Again, load and concentration estimated using the two methods are not comparable. The better comparison is to evaluate the results of the trend test.

For the regression on residuals method, the trend magnitude is equivalent to the slope of the linear regression of water year against annual flow-adjusted loads. The slope was $-8,072$ tons of change in salinity load per year; $p$-value was less than 0.001 . The percent change was -0.78 percent per year, which is equivalent to a net decrease of 15 percent over 19 years. The 95 -percent $\mathrm{CI}$ ranged from -10 percent to 
-19 percent. In terms of salinity load (coefficient multiplied by 19 years), the net change was a decrease of 153,000 tons with a 95-percent $\mathrm{CI}$ that ranged from a decrease of 108,000 tons to a decrease of 199,000 tons (table 4).

For the normalized regression method, the p-value was less than 0.001 , which indicated a highly significant time trend. Annual percent change in flow-normalized salinity loads was a significant decrease of 0.87 percent which is a net decrease of 17 percent over 19 years. The net decrease in flownormalized load using the normalized regression method was between 202,000 and 212,000 tons (95-percent CI) and the mean net decrease was 207,000 tons (table 4).

\section{Comparison Period: 1986-2003}

The third comparison is for the period 1986-2003 which was reported in Leib and Bauch (2008). Consequently, the comparison is of the published results in Leib and Bauch relative to the normalized regression method results presented here.

Leib and Bauch (2008) reported an estimated mean annual salinity load of $1,761,000$ tons and a mean annual salinity concentration of $512 \mathrm{mg} / \mathrm{L}$ during 1986-2003 (table 4). The net change over the 18-year study period was a decrease of 18 percent. This corresponded with a net decrease of 202,000 tons during 1986-2003 (table 4). The 95-percent confidence interval was not published. Mean annual salinity load and concentration were estimated using SLOAD (Liebermann and others, 1987) while the estimates in the other comparisons and in the remainder of this report were calculated using S-LOADEST. Estimates may be different between the two programs for various reasons. SLOAD included specific conductance and did not include time or seasonality as explanatory variables in the regression models. Additionally, when the response variable (salinity load or concentration) was transformed, SLOAD did not perform a bias correction when the variable was untransformed back into original units.

For the normalized regression method, the final model equation was (equation 10):

$$
\begin{aligned}
\ln \hat{L} & =8.07+0.44\left(\ln Q-\ln Q^{*}\right)-0.01\left(t-t^{*}\right) \\
& -0.21(\sin (2 \pi T))-0.04(\cos (2 \pi T)) \\
& +0.04(\sin (6 \pi T))-0.01(\cos (6 \pi T))+\varepsilon
\end{aligned}
$$

The p-value on the time term was less than 0.001 , which indicated a highly significant time trend. Annual percent change in flow-normalized salinity load was a decrease of 1.3 percent which was a net decrease of 23 percent over 18 years. The net change in flow-normalized load was between $-268,000$ and -278,000 (95-percent CI) and the mean net decrease was 273,000 tons (table 4).

Based on these comparisons, the estimated change in salinity load is smaller using the regression on residuals method relative to the normalized regression method. Consequently, the trends identified in previous studies using the regression on residuals method could be considered to be conservative relative to the trend calculated using the normalized regression method. Alley (1988) compared the performance of four different trend tests: multiple regression, regression on residuals, a Kendall test on residuals, and an adjusted variable Kendall test on residuals. The multiple regression method in Alley (1988) is equivalent to the normalized regression in this report. The regression on residuals in Alley (1988) is equivalent to the regression on residuals method in this report. Using Monte Carlo experiments, Alley (1988) showed that the trend slope tends to be underestimated by the regression on residuals method. Relative to the regression on residuals method, power was higher and errors were less for the multiple regression method (Alley, 1988). The conclusions of these tests supported the use of the normalized regression method presented in this report.

\section{Salinity Trends by Subbasin}

The model coefficients from the regression analysis for each site are listed in table 8 in the Appendix at the back of this report. Results of the load calculations and trend tests for each site are summarized in table 5. The 95-percent $\mathrm{CI}$ is presented in table 5 as well as in the text. In the text, the mean net flow-normalized change is presented followed by the 95-percent CI in parentheses. Figures 6 through 23 show significant trends and each figure has three components: a line, a dark gray bar, and a light gray bar. The line represents the trend of the mean annual flow-normalized loads calculated by the final model. The dark gray bar represents the annual load calculated using the daily streamflow, the estimated annual salinity loads (not flow-normalized). This calculation is explained in the Regression on Residuals Method section of this report where the streamflow value provided in the estimation dataset was daily streamflow reported at the continuous streamflow-gaging station. The light gray bar represents the salinity load calculated from the model equation as if there were no linear time trend. The first step of this calculation was to determine the annual percent change using equation 5 as described in the Normalized Regression Method section of this report. For each year of the study period, with WY 1989 as year zero, the annual percent change was accumulated until the final year of the study period. The accumulated percent change was converted to load by multiplying it by the estimated mean annual salinity load (dark gray bar) for the corresponding year. The result was an annual estimate of the change in salinity load as a result of the linear time trend relative to the estimated mean annual salinity load. When the trend was negative, the calculated changes were positive and the light gray bar is higher than the dark gray bar. When the trend was positive, the calculated changes were negative and the light gray bar is lower. The light gray bar was calculated using only the coefficient on the time term and did not include the coefficient on the quadratic-time term (when significant). The trend line on the plots is parabolic in shape when the quadratic-time term was significant. 
Table 5. Summary of significant results from trend analysis using normalized regression for selected sites in the Gunnison River Basin, Colorado.

[Negative numbers indicate a decrease over time; NS, no significant net time trend at p-value 0.05 or less; Italics indicate marginally significant results at p-value greater than 0.05 but less than 0.10 ; --, data not calculated because there was no significant time trend]

\begin{tabular}{|c|c|c|c|c|c|c|c|}
\hline $\begin{array}{c}\text { U.S. } \\
\text { Geological } \\
\text { Survey } \\
\text { streamflow- } \\
\text { gaging station } \\
\text { number, } \\
\text { figures 1-5 }\end{array}$ & U.S. Geological Survey streamflow-gaging station name & $\begin{array}{c}\text { Estimated } \\
\text { mean annual } \\
\text { salinity } \\
\text { concentration, } \\
\text { in milligrams } \\
\text { per liter }\end{array}$ & $\begin{array}{l}\text { Estimated } \\
\text { mean annual } \\
\text { salinity load, } \\
\text { in tons }\end{array}$ & $\begin{array}{l}\text { Net change } \\
\text { in flow- } \\
\text { normalized } \\
\text { load, in } \\
\text { percent }\end{array}$ & $\begin{array}{l}\text { Net change } \\
\text { in flow- } \\
\text { normalized } \\
\text { load, in } \\
\text { tons }\end{array}$ & $\begin{array}{l}\text { Lower } 95 \\
\text { percent } \\
\text { confidence } \\
\text { level for } \\
\text { net change } \\
\text { in flow- } \\
\text { normalized } \\
\text { load, in tons }\end{array}$ & $\begin{array}{c}\text { Upper } 95 \\
\text { percent } \\
\text { confidence } \\
\text { level for } \\
\text { net change } \\
\text { in flow- } \\
\text { normalized } \\
\text { load, in tons }\end{array}$ \\
\hline \multicolumn{8}{|c|}{ Study period water years 1989-2004 } \\
\hline 09114500 & Gunnison River near Gunnison, Colo. & 121 & 72,400 & NS & NS & -- & -- \\
\hline 09124500 & Lake Fork at Gateview, Colo. & 97 & 17,100 & 16 & 2,620 & 2,560 & 2,680 \\
\hline 09126000 & Cimarron River near Cimarron, Colo. & 86 & 7,630 & 5.9 & 479 & 403 & 556 \\
\hline 09128000 & Gunnison River below Gunnison Tunnel, Colo. & 116 & 110,000 & NS & NS & -- & -- \\
\hline 09132500 & North Fork Gunnison River near Somerset, Colo. & 92 & 32,900 & 6.8 & 2,150 & 1,940 & 2,360 \\
\hline 09134000 & Minnesota Creek near Paonia, Colo. & 298 & 3,420 & -16 & -645 & -693 & -597 \\
\hline 09143000 & Surface Creek near Cedaredge, Colo. & 52 & ${ }^{1} 1,650$ & NS & NS & -- & -- \\
\hline 09143500 & Surface Creek at Cedaredge, Colo. & 65 & ${ }^{1} 1,420$ & NS & NS & -- & -- \\
\hline 09144250 & Gunnison River at Delta, Colo. & 469 & 577,000 & -26 & $-179,000$ & $-185,000$ & $-173,000$ \\
\hline 09147000 & Dallas Creek near Ridgway, Colo. & 425 & 11,400 & NS & NS & -- & -- \\
\hline 09146200 & Uncompahgre River near Ridgway, Colo. & 433 & 47,900 & -9.8 & $-5,160$ & $-5,460$ & $-4,860$ \\
\hline 09147025 & Uncompahgre River below Ridgway Reservoir, Colo. & 372 & 66,500 & -9.7 & $-7,860$ & $-8,300$ & $-7,430$ \\
\hline 09147500 & Uncompahgre River at Colona, Colo. & 387 & 77,500 & -7.8 & $-7,160$ & $-7,700$ & $-6,620$ \\
\hline 09149500 & Uncompahgre River at Delta, Colo. & 1,110 & 281,000 & -17 & $-55,500$ & $-56,800$ & $-54,200$ \\
\hline 09152500 & Gunnison River near Grand Junction, Colo. & 604 & $1,031,000$ & -21 & $-247,000$ & $-252,000$ & $-241,000$ \\
\hline \multicolumn{8}{|c|}{ Study period water years 1989-2007 } \\
\hline 09114500 & Gunnison River near Gunnison, Colo. & 122 & 72,400 & 3.9 & 2,890 & 2,670 & 3,110 \\
\hline 09128000 & Gunnison River below Gunnison Tunnel, Colo. & 117 & 107,000 & 4.4 & 5,100 & 4,790 & 5,420 \\
\hline 09132500 & North Fork Gunnison River near Somerset, Colo. & 92 & 33,500 & NS & NS & -- & -- \\
\hline 09146200 & Uncompahgre River near Ridgway, Colo. & 428 & 48,200 & -10 & $-5,450$ & $-5,730$ & $-5,180$ \\
\hline 09152500 & Gunnison River near Grand Junction, Colo. & 599 & $1,039,000$ & -17 & $-207,000$ & $-212,000$ & $-202,000$ \\
\hline
\end{tabular}

${ }^{1}$ Annual estimates for these two sites are actually from April through September only. There were not sufficient data to include the remaining months. 
The Upper Gunnison River Basin is made up of subbasins 1 and 2 and the basin outflow is at the Gunnison River at the Gunnison Tunnel, Colo. (streamflow-gaging station 09128000) (figs. 1 and 2). The Lower Gunnison River Basin refers to the portions of subbasins 3,4 , and 5 downstream from the Gunnison Tunnel (figs. 1 and 3) and the basin outflow (subbasin 5) is the Gunnison River near Grand Junction, Colo. (streamflow-gaging station 09152500). Salinity concentration and load are presented for each site and subbasin and as they accumulate downstream. The cumulative totals in the Lower Gunnison subbasins incorporate the results from the Upper Gunnison River Basin sites and subbasins.

\section{Subbasin 1}

Subbasin 1 is located furthest upstream in the watershed. There was only one site in subbasin 1, the Gunnison River near Gunnison, Colo. (streamflow-gaging station 09114500), and it had sufficient data for trend analysis for each of the two study periods. The majority of irrigated acreage in subbasin 1 occurs on Quaternary deposits on the valley floors of Ohio Creek and the East River (figs. 2 and 5). The Quaternary deposits found in the Ohio Creek valley are landslide deposits that potentially were derived from the Mancos Shale, which is high in salt content. The valley walls of both streams contain outcrops of Mancos Shale (fig. 5). In 2000, about $49 \mathrm{mi}^{2}$ of land were irrigated in the basin which was a decrease of $3 \mathrm{mi}^{2}$ from 1993 (Techni Graphic Systems, Inc., 2004). Gunnison, Crested Butte, and Mount Crested Butte all are located in this subbasin. Between 1990 and 2000, all three towns increased in population by 24 percent, 75 percent and 168 percent, respectively (U.S. Census Bureau, 2010). The major change in land cover was a conversion of about $12 \mathrm{mi}^{2}$ of forested land to grassland (Fry and others, 2009).

The estimated mean annual salinity load was 72,400 tons during 1989-2004 and the same during 1989-2007. Flownormalized salinity concentration and load did not change significantly during 1989-2004 (table 5). During 1989-2007, there was a significant upward trend in flow-normalized salinity concentration and load of 3.9 percent $(\mathrm{p}=0.038)$. Flownormalized salinity load increased by 2,890 tons (table 5 ; fig. 6); the 95-percent CI was 2,670 to 3,110 tons. According to the plot of modified residuals, the increase in flow-normalized salinity concentration and load began around WY 2001 and continued through WY 2007. The increase was likely too small to be detected by WY 2004. The upward trend in salinity load could be because of increased urbanization. A previous study found that the conversion of land from irrigated agriculture to an urban land cover is most likely to reduce salinity (Mayo, 2008). However, in subbasin 1, the majority of land that was converted to urban was previously either a forested land cover or grassland (Fry and others, 2009) and little is known about the changes in salinity resulting from a change from unirrigated to urban land-cover. The NLCD change product found that agricultural land increased by $1 \mathrm{mi}^{2}$ from WY 1992 to WY 2001 in subbasin 1 and, according to

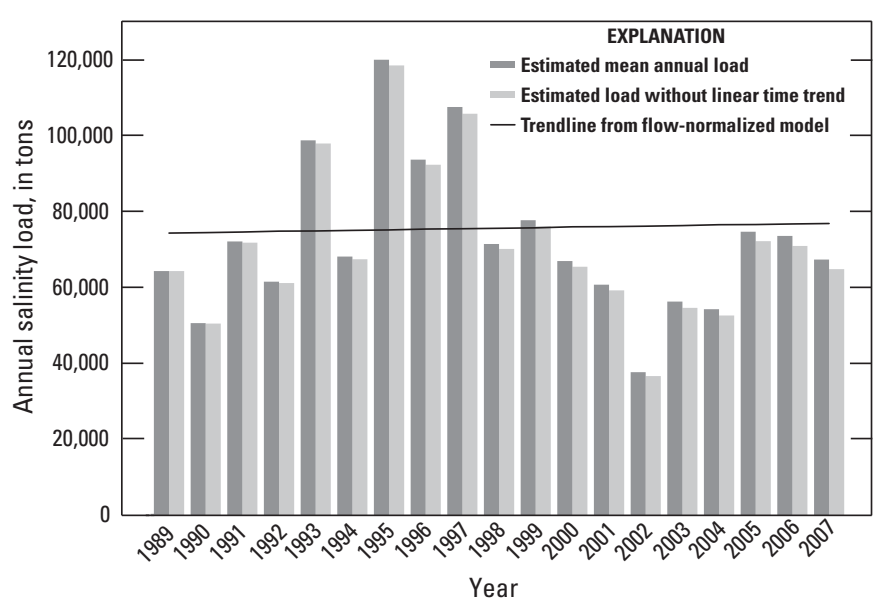

Figure 6. Estimated annual salinity load, annual salinity load had there been no time trend, and the trend line for the flownormalized concentration and load at streamflow-gaging station 09114500 during water years 1989-2007.

Techni Graphic Systems, Inc. (2004), irrigated acreage decreased by $3 \mathrm{mi}^{2}$ from 1993-2000. Decreased agriculture is more likely to result in decreased salinity. The loss of forest and increase in grassland may have contributed to the upward trend. The effect of converting forested land to grassland is unknown.

\section{Subbasin 2}

Subbasin 2 includes subbasin 1 (detailed in the previous subsection), two additional sites within the basin, and the site at the mouth of the subbasin, Gunnison River below Gunnison Tunnel, Colo. (streamflow-gaging station 09128000) (fig. 2). Most of the near-surface geology in this subbasin has a relatively low salt content. In the upper reaches, the geology is dominated by Triassic-aged or older formations (fig. 5). Tertiary volcanic deposits crop out from the San Juan Mountains through the middle of the subbasin. The Mancos Shale crops out in part of the subbasin (fig. 5). The most significant Mancos Shale outcrop is found in the reaches of subbasin 1 and was discussed in the Subbasin 1 section of this report. Areas near Tomichi Creek, in the eastern or southeastern part of the subbasin, are underlain by Mancos Shale or Quaternary landslide deposits that may have been derived from Mancos Shale. However, the main stem of Tomichi Creek flows through Quaternary-aged alluvial deposits that are low in salt content. Throughout subbasin 2, the irrigated land is underlain by Quaternary-aged deposits and Mancos Shale (figs. 2 and 5). Additional outcrops of Mancos Shale underlie tributaries to the Gunnison River downstream from the Aspinall Unit which may have an effect on the site at the mouth of the subbasin, Gunnison River below Gunnison Tunnel, Colo. The outcrops generally are in the lower reaches of the tributaries that flow into the main stem of the Gunnison River. Some of the outcrops are surrounded by Quaternary-aged landslide deposits which may have been derived from Mancos Shale. The areas 
upstream from the sites located on the Lake Fork and the Cimarron River are underlain by Tertiary- and Quaternary-aged formations, which are not known to be sources of salinity in surface water. There is little to no irrigation in the areas upstream from the two sites (fig. 2). Therefore, the salinity concentrations and loads at these two sites probably are indicative of the lower end of the range of natural salinity concentrations and loads.

Urbanization and land-use changes were minimal in subbasin 2 during 1989-2004. The total population of the five towns located in this subbasin increased from 5,781 in 1990 to 8,144 in 2000 (U.S. Census Bureau, 2010). The increased population corresponds to a small increase in urban land cover of $0.2 \mathrm{mi}^{2}$, the majority of which occurred in subbasin 1. Most of the land converted to urban land cover was previously forested. The largest change in land cover in the subbasin was the conversion of more than $36 \mathrm{mi}^{2}$ of forested land to grassland (Fry and others, 2009).

Estimated mean annual salinity load at Lake Fork at Gateview, Colo. (streamflow-gaging station 09124500) was 17,100 tons. There was a significant upward trend in annual flow-normalized salinity concentration and load of 16 percent $(\mathrm{p}<0.001)$ during 1989-2004 (table 5, fig. 7). Flow-normalized salinity load increased by 2,620 tons (95-percent CI 2,560 to 2,680 tons)

At the Cimarron River near Cimarron, Colo. (streamflowgaging station 09126000) estimated mean annual salinity load was 7,630 tons. The streamflow term in this model was not significant and a single linear regression of natural logtransformed streamflow against natural log-transformed salinity also indicated no significant relation between streamflow and salinity. Flow-normalized results are still presented in order to compare these results to those of the rest of the study area. During the study period, the net trend of 5.9 percent was marginally significant, $\mathrm{p}=0.082$ (table 5 ). This corresponded

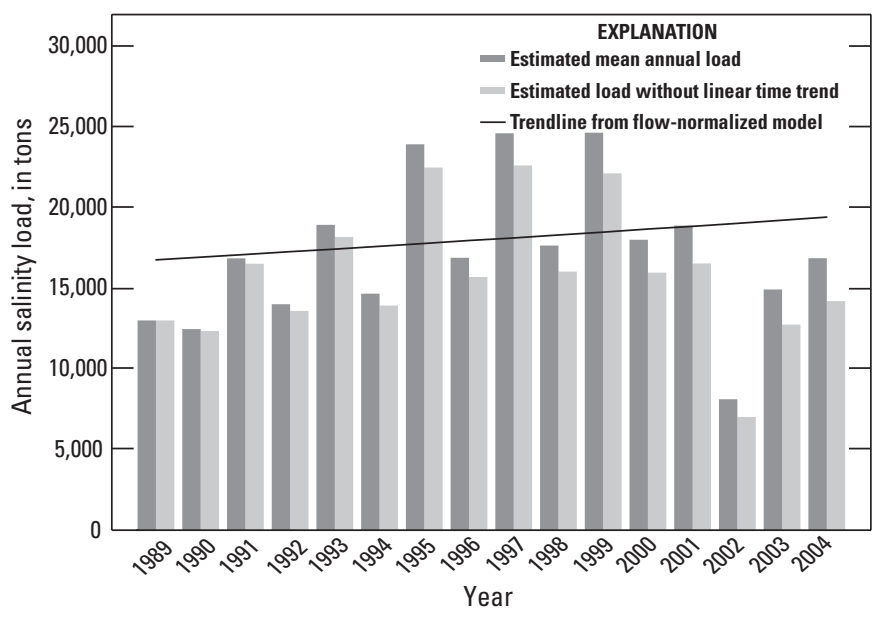

Figure 7. Estimated annual salinity load, annual salinity load had there been no time trend, and the trend line for the flownormalized concentration and load at streamflow-gaging station 09124500 during water years 1989-2004.

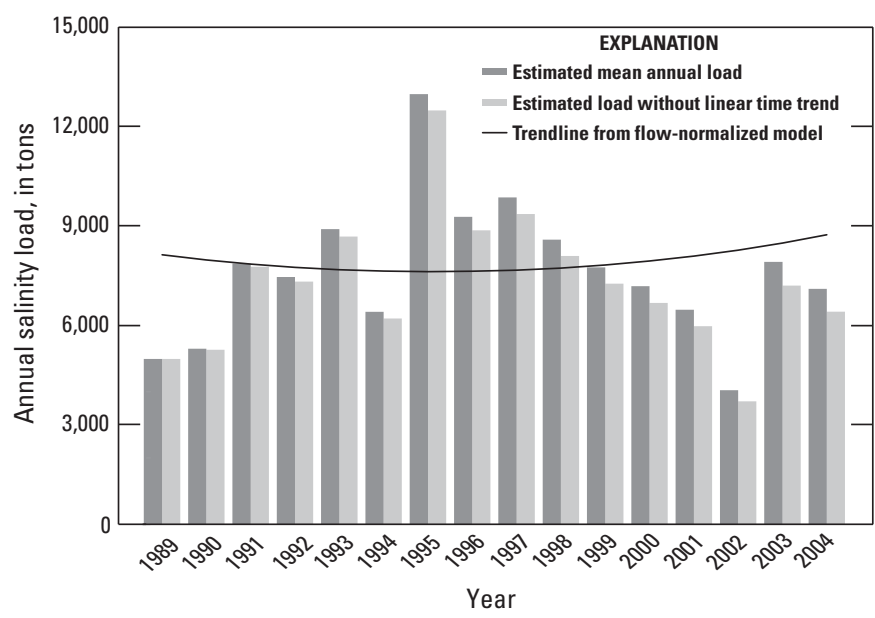

Figure 8. Estimated annual salinity load, annual salinity load had there been no time trend, and the trend line for the flownormalized concentration and load at streamflow-gaging station 09126000 during water years 1989-2004.

with an increase in flow-normalized salinity load of 479 tons (95-percent CI 403 to 556 tons). However, the quadratic-time term was significant, $p<0.001$, (fig. 8 ) and the minimum flownormalized salinity concentration and load occurred around WY 1995. The minimum was 6 percent less than the flownormalized concentration or load in WY 1989 and 12 percent less than in WY 2004. The plot of modified residuals against time indicated that after around WY 1997, flow-normalized salinity load increased and then leveled out around WY 2002.

The Gunnison River below Gunnison Tunnel, Colo. (streamflow-gaging station 09128000), located at the mouth of subbasin 2, represents the accumulation of subbasin 1, streamflow-gaging stations 09124500 and 09126000 , other smaller tributaries, and a portion of the Gunnison River (figs. 1 and 2). Data for this site were sufficient for analysis of trends for the two study periods. Estimated mean annual salinity load was 110,000 tons during 1989-2004 and 107,000 tons during 1989-2007. There was no significant trend during 1989-2004 (table 5). During 1989-2007, there was a significant upward trend ( $\mathrm{p}=0.035$ ) of 4.4 percent or 5,100 tons ( 95 -percent CI 4,790 to 5,420 tons). The quadratic time term was significant for 1989-2004 $(\mathrm{p}=0.003)$ and for 1989-2007 $(\mathrm{p}=0.001)$. The minimum occurred in WY 1997 in both regression models (figs. 9 and 10) and salinity concentration and load were between 5 and 7 percent less than the beginning and ending years of the two study periods. These results indicate that increases have continued since WY 1997 and, as of WY 2007, are significantly greater than estimates from WY 1989.

In subbasin 2, the only trends in flow-normalized salinity concentration and load during 1989-2004 were upward trends at the Lake Fork at Gateview and the Cimarron River near Cimarron sites (marginally significant) which totaled around 3,000 tons. The only urban center associated with these two sites is Lake City which is upstream of the site on the Lake Fork and had a population of 375 that did not change between 


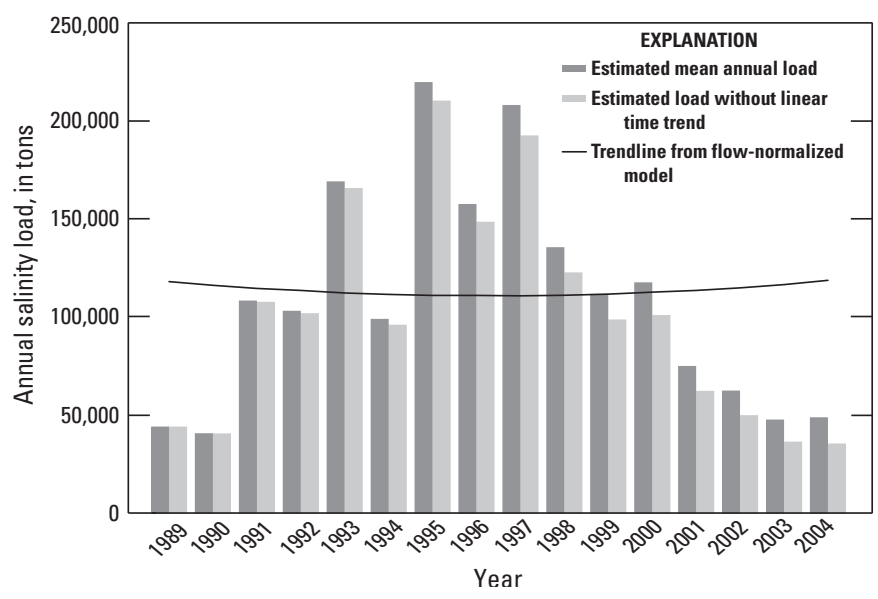

Figure 9. Estimated annual salinity load, annual salinity load had there been no time trend, and the trend line for the flow-normalized concentration and load at streamflow-gaging station 09128000 during water years 1989-2004.

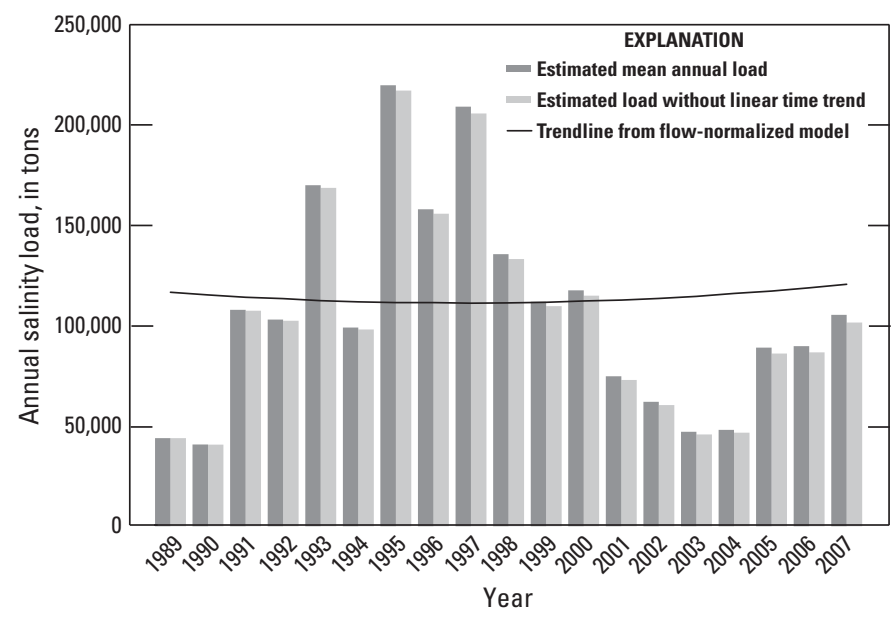

Figure 10. Estimated annual salinity load, annual salinity load had there been no time trend, and the trend line for the flownormalized concentration and load at streamflow-gaging station 09128000 during water years 1989-2007.

2000 and 2010 (U.S. Census Bureau, 2010). Additionally, there is little to no irrigated agriculture upstream of either site (fig. 2). During 1989-2007, the only trends were upward trends at the Gunnison River near Gunnison site and below the Gunnison Tunnel. The net upward trends are most likely attributable to changes in land cover during the study period. The major change in land cover in the subbasin was a conversion of forested land to grassland. The change in the direction of the trend, from downward to upward, in WY 1995 at the Cimarron River site and in WY 1997 at the Gunnison River at the Gunnison Tunnel site (both study periods) imply that changes in land cover had an effect or a change in land or reservoir management occurred. Historical data available from the USBR indicated an increase in fluctuation of the reservoir levels at Crystal and Morrow Point Reservoirs beginning in the early 1990s. Also in the summer 1995, the inflow and the corresponding release to and from the reservoirs was higher than in other years (http://www.usbr.gov/uc/crsp/GetSiteInfo, accessed May 17, 2011).

\section{Subbasin 3}

Subbasin 3 contains both Upper Gunnison subbasins (1 and 2), the North Fork of the Gunnison River near Somerset, Colo. (streamflow-gaging station 09132500), Minnesota Creek near Paonia, Colo. (streamflow-gaging station 09134000), the two Surface Creek sites (streamflow-gaging stations 09143000 and 09143500), and the Gunnison River at Delta, Colo. (streamflow-gaging station 09144250) which is located at the mouth of the subbasin. The first four of those five sites are located in the upper reaches of the subbasin and have little to no irrigated agriculture in their drainage areas (fig. 3). The geology of the upper elevation areas is dominated by Tertiary- and Quaternary-aged formations with a band of the Mesaverde Group in the mid to upper elevations (fig. 5). In the lower elevations, the geology is dominated by Mancos Shale capped with Quaternary-aged glacial and gravel deposits. The youngest of those deposits are found at the highest elevations of the subbasin and generally increase in age with decreasing elevation. Cedaredge, Hotchkiss, Paonia, and Crawford are located in subbasin 3; Delta and Orchard City are located partially within the subbasin. These 6 towns and the towns previously described for subbasins 1 and 2 make up the population centers in subbasin 3 . The populations of all of these population centers increased by varying amounts between 1990 and 2000 (U.S. Census Bureau, 2010). Paonia had the smallest growth at about 7 percent. The largest growth was in Delta which grew by 70 percent relative to the 1990 count (U.S. Census Bureau, 2010). This growth resulted in increased urban land cover of more than $3 \mathrm{mi}^{2}$ from 1992 to 2001. The majority of this land was grassland in 1992 (Fry and others, 2009). Almost $17 \mathrm{mi}^{2}$ of grassland were converted to agriculture, though the largest change in land cover was a conversion of almost $47 \mathrm{mi}^{2}$ from forested land to grassland, as was observed also in subbasins 1 and 2 (Fry and others, 2009).

Estimated mean annual salinity load at the North Fork of the Gunnison River near Somerset, Colo. (streamflow-gaging station 09132500) was 32,900 tons during 1989-2004 and 33,500 tons during 1989-2007 (table 5). There was a marginally significant upward trend in flow-normalized concentration and load of 6.8 percent during 1989-2004 ( $\mathrm{p}=0.091)$. There was no significant net trend in during 1989-2007 (table 5). The quadratic-time term was significant for the 1989-2004 study period $(\mathrm{p}=0.007)$ and the 1989-2007 study period $(p=0.024)$ (figs. 11 and 12). The maximum flow-normalized salinity load occurred between WY 1997 and WY 1999. For the 1989-2004 study period, the maximum flow-normalized salinity load (WY 1997) was 16 percent more than in WY 1989 and 11 percent more than in WY 2004. For the 19892007 study period, the maximum flow-normalized salinity 


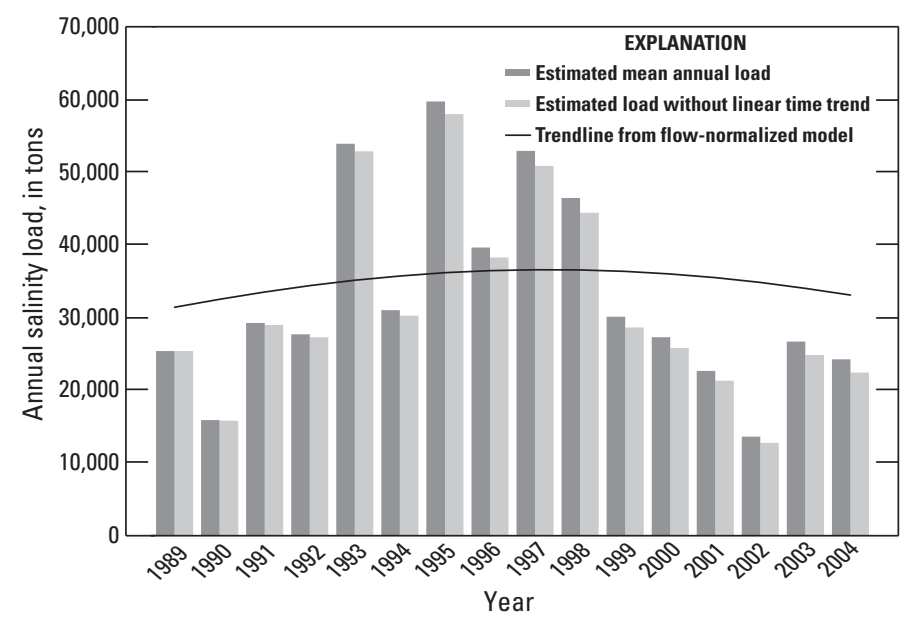

Figure 11. Estimated annual salinity load, annual salinity load had there been no time trend, and the trend line for the flownormalized concentration and load at streamflow-gaging station 09132500 during water years 1989-2004.

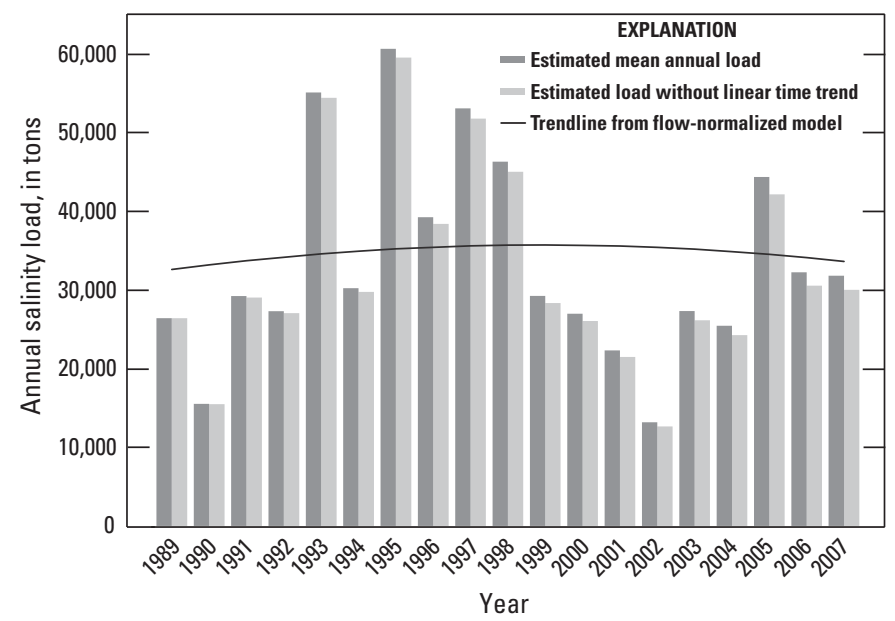

Figure 12. Estimated annual salinity load, annual salinity load had there been no time trend, and the trend line for the flownormalized concentration and load at streamflow-gaging station 09132500 during water years 1989-2007.

load (WY 1999) was 10 percent more than in WY 1989 and 6.3 percent more than in WY 2007. The modified-residual plots indicated that, in the early 1990's, flow-normalized salinity concentration and load leveled out until the late 1990's when it began to decrease slowly. The trend test results indicated that the decrease continued after WY 2004 and flownormalized salinity concentration and load in WY 2007 were not significantly different from those in WY 1989. The North Fork of the Gunnison River near Somerset, Colo. (streamflow-gaging station 09132500) is underlain mostly by the Mesaverde Group and Tertiary-aged formations (fig. 5). There are a few Quaternary-aged outcrops in the headwaters of the watershed. The small amount of irrigated agriculture in this area is found mainly near the East and West Muddy
Creeks in the headwaters of the watershed (fig. 3). Based on the geology and minimal irrigated agriculture, results from this site may indicate that changes in land cover had an effect.

Estimated mean annual salinity load for Minnesota Creek near Paonia, Colo. (streamflow-gaging station 09134000) was 3,420 tons (table 5). There was a significant downward trend in annual flow-normalized salinity concentration and load $(\mathrm{p}=0.025)$ of 16 percent during 1989-2004 (table 5; fig. 13). The net change in flow-normalized salinity loads was a decrease of 645 tons (95-percent CI -693 to -597 tons) (table 5). Concentrations were two to three times higher at this site relative to the other sites located upstream from the Gunnison River at Delta, Colo. (streamflow-gaging station 09144250) in subbasin 3 (table 5). The quadratic-time term was significant $(\mathrm{p}<0.001)$ and the shape of the parabola and the modified-residual plot indicated that the maximum flow-normalized salinity concentration and load occurred in WY 1995. The maximum was 22 percent more than estimates from WY 1989 and 45 percent more than from WY 2004. The drainage area of this site is underlain by Mancos Shale (fig. 5) which was the likely cause of the higher concentrations observed at this site. Irrigation in this small drainage begins downstream from this site, so this site could be an indicator of the changes as a result of landcover change or of natural salinity concentrations and loading from the Mancos Shale (fig. 3).

Surface Creek near Cedaredge, Colo. (streamflow-gaging station 09143000) represents the smallest watershed of the salinity trend sites with a drainage area of only $27 \mathrm{mi}^{2}$ and no irrigated agriculture. Means and totals include estimates from April through September only. The estimated mean salinity load from April through September of the study period was 1,650 tons (table 5). There was no significant time trend at this site. Mean estimated salinity concentration was $52 \mathrm{mg} / \mathrm{L}$.

Surface Creek at Cedaredge, Colo. (streamflow-gaging station 09143500) is about 7 river miles downstream and

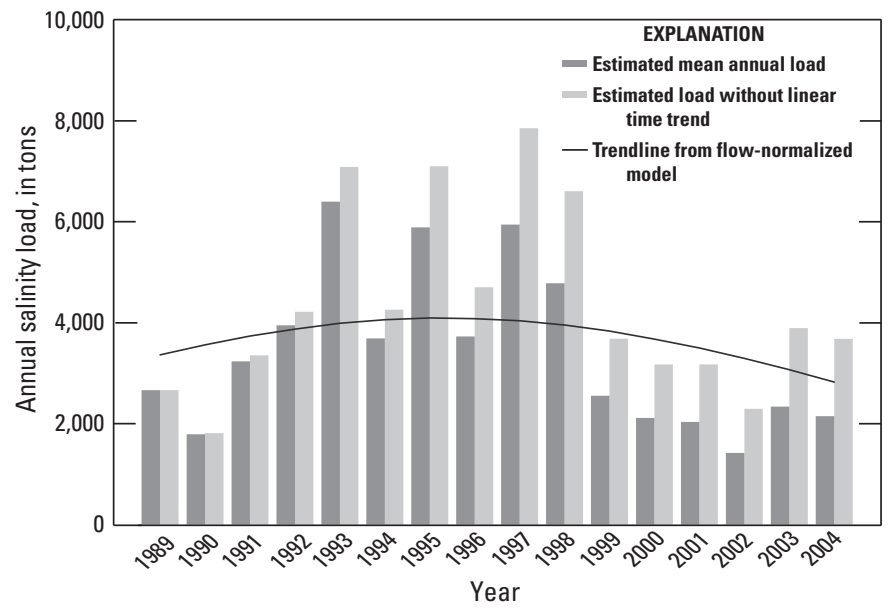

Figure 13. Estimated annual salinity load, annual salinity load had there been no time trend, and the trend line for the flownormalized concentration and load at streamflow-gaging station 09134000 during water years 1989-2004. 
represents the second smallest watershed $\left(39 \mathrm{mi}^{2}\right)$ of the salinity trend sites. Estimated mean salinity load from April through September for the study period was 1,420 tons. There was no significant net trend in annual flow-normalized salinity concentration or load at this site (table 5). However, the quadratic-time term was significant $(\mathrm{p}=0.005)$ and the shape of the parabola and the modified-residual plot indicate that the maximum flow-normalized salinity concentration and load occurred in WY 1997 (fig. 14). The maximum was 22 percent more than estimates from WY 1989 and 13 percent more than from WY 2004.

The Gunnison River at Delta, Colo. (streamflow-gaging station 09144250) site represents subbasins 1, 2, and 3. At this site, the estimated mean annual salinity load was 577,000 tons during 1989-2004. There was a significant downward trend in flow-normalized salinity concentration and load $(\mathrm{p}<0.001)$ of 26 percent during 1989-2004 (table 5; fig. 15). The net change in flow-normalized salinity load was a decrease of 179,000 tons (95-percent CI $-185,000$ to $-173,000$ tons). Relative to the Uncompahgre River at Delta site, which flows into the Gunnison River just downstream from this site (subbasin 4), the concentrations at this site are half of those from the Uncompahgre River site but loads from this site are double those from the Uncompahgre River site (table 5) because of higher streamflow in the Gunnison River at Delta. The upstream sites in the subbasin that were included in the study that had significant trends had a cumulative increase of 4,600 tons as of WY 2004 and 7,990 as of WY 2007. Since the mid-1990s, there was an overall increase of about 4,030 tons in the upstream sites as of WY 2004 and 7,330 as of WY 2007. The majority of the negative trend found at the Gunnison River at Delta site remains unexplained by trends in the upstream sites.

It is difficult to determine the reason for the decreased salinity at the Gunnison River at Delta site. A portion of the decrease could be attributed to increased urbanization,

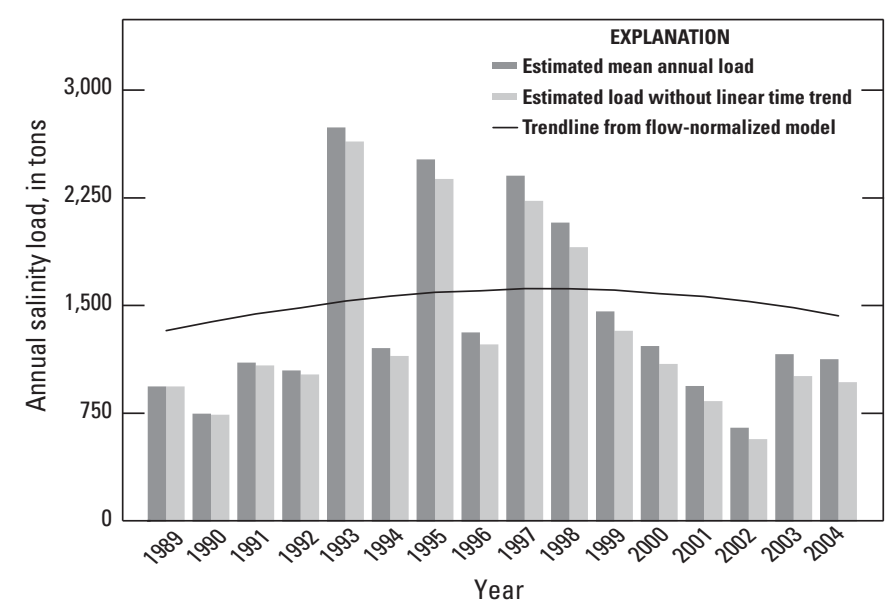

Figure 14. Estimated annual salinity load, annual salinity load had there been no time trend, and the trend line for the flownormalized concentration and load at streamflow-gaging station 09143500 during water years 1989-2004.

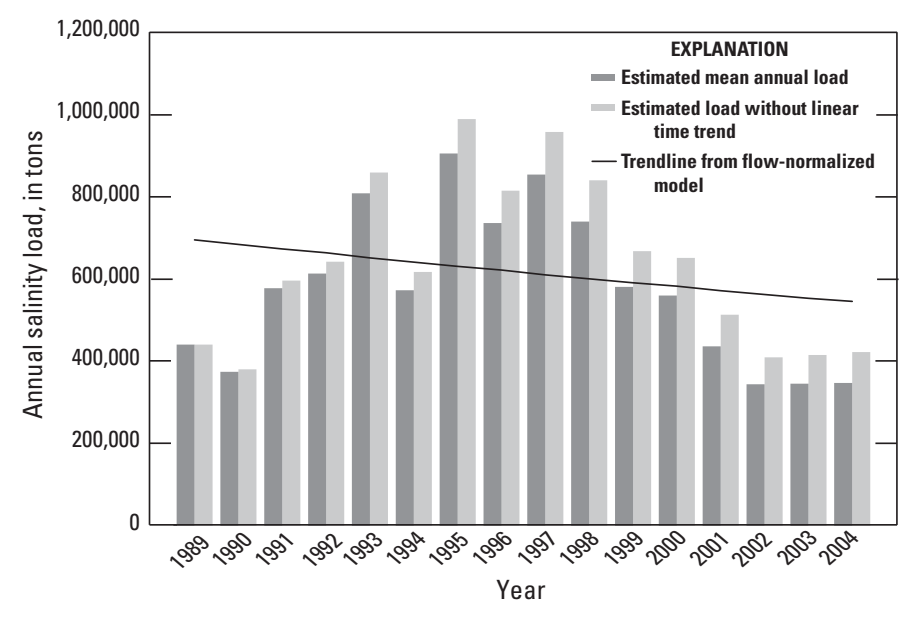

Figure 15. Estimated annual salinity load, annual salinity load had there been no time trend, and the trend line for the flownormalized concentration and load at streamflow-gaging station 09144250 during water years 1989-2004.

particularly in Delta, although urban land cover increased by only $3 \mathrm{mi}^{2}$ in the entire subbasin. Agricultural land cover increased between 1992 and 2001 in subbasin 3, which would typically correspond with an increase in salinity loads. Most of the land that was converted to agriculture was grassland $\left(17 \mathrm{mi}^{2}\right)$ or forest $\left(8.6 \mathrm{mi}^{2}\right)$ in 1992 (Fry and others, 2009) and was previously not irrigated. However, irrigated acreage decreased between 1993 and 2000 and the use of sprinklers for irrigation increased (Techni Graphic Systems, Inc., 2004). Sprinklers have been shown to have 70-90 percent efficiency (U.S. Department of Agriculture, 2007; Bureau of Reclamation, 2009) and the change in irrigation practices might explain at least a portion of the decrease in flow-normalized salinity concentration and load. According to the NLCD Change Product, $47 \mathrm{mi}^{2}$ were converted from a forested to grassland land cover (Fry and others, 2009). It is possible that this land-cover change also contributed to the trend.

\section{Subbasin 4}

Subbasin 4, the Uncompahgre River watershed, enters the Gunnison River just downstream from the Gunnison River at Delta site. It is the subbasin most affected by agricultural activities and is dominated by Mancos Shale or geological formations deposited on top of Mancos Shale (figs. 3 and 5). Flow-normalized salinity concentrations throughout this watershed generally are at least four times greater than those measured and modeled in the Upper Gunnison sites (table 5). Between 1992 and 2001, agricultural land cover in the subbasin increased by $28 \mathrm{mi}^{2}$. Generally, grasslands were converted to agriculture $\left(29 \mathrm{mi}^{2}\right)$ or forest $\left(37 \mathrm{mi}^{2}\right)$ (Fry and others, 2009). The increase in agricultural land cover observed in the NLCD change product (Fry and others, 2009) corresponds with a smaller increase of $7 \mathrm{mi}^{2}$ of irrigated land between 1993 and 2000 (Techni Graphic Systems, Inc., 2004). The irrigated 
land is almost completely underlain by Mancos Shale capped with Quaternary-aged gravels and alluvium (Tweto, 1979; Green, 1992). The towns in the subbasin include Ouray, Ridgway, Montrose, Olathe, and a portion of Delta, listed in order from the headwaters to the mouth. The population in each town grew by at least 25 percent between 1990 and 2000 (U.S. Census Bureau, 2010). Urban land increased by $5 \mathrm{mi}^{2}$ and $4.4 \mathrm{mi}^{2}$ of that land was previously designated as grassland (Fry and others, 2009). However, the urbanized areas also are near irrigated agriculture, so it is difficult to differentiate the effect of increased urbanization (fig. 3).

Dallas Creek near Ridgway, Colo. (streamflow-gaging station 09147000) is a tributary site located in the upstream section of the basin. Almost the entire watershed is underlain by Mancos Shale capped in some areas by Quaternary-aged alluvium. Estimated mean annual salinity loads were 11,400 tons during the study period (table 5). There was no significant trend in flow-normalized salinity concentration and load; however, the quadratic-time term was significant $(p=0.031)$. The minimum flow-normalized salinity concentration and load occurred in WY 1998 and was 11 percent less than in WY 1989 and 6 percent less than in WY 2004 (fig. 16). The estimated mean concentration was $425 \mathrm{mg} / \mathrm{L}$ (table 5).

The site Uncompahgre River near Ridgway Colo. (streamflow-gaging station 09146200) is located downstream from where the Dallas Creek site enters the Uncompahgre River and upstream from the Ridgway Reservoir (fig. 3). Data for this site were sufficient to analyze two study periods. Estimated mean annual salinity loads were 47,900 tons during 1989-2004 and 48,200 tons during 1989-2007. Annual flow-normalized salinity concentration and load significantly decreased $(\mathrm{p}=0.013)$ by 9.8 percent during 1989-2004 (table 5; fig. 17). The net decrease in flow-normalized salinity load was 5,160 tons ( 95 -percent CI $-5,460$ to $-4,860$ tons). During 1989-2007, annual flow-normalized salinity concentration and load significantly decreased $(\mathrm{p}=0.016)$

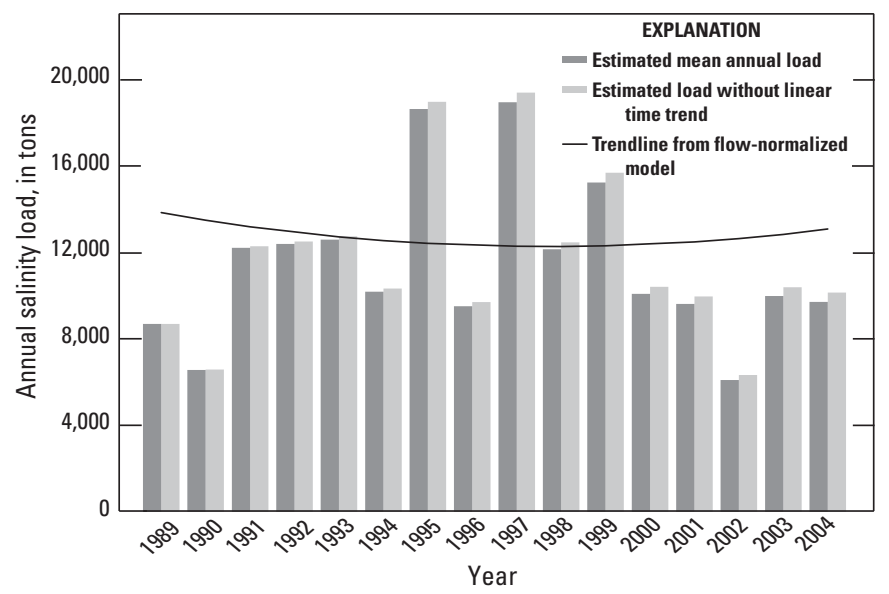

Figure 16. Estimated annual salinity load, annual salinity load had there been no time trend, and the trend line for the flownormalized concentration and load at streamflow-gaging station 09146200 during water years 1989-2004.

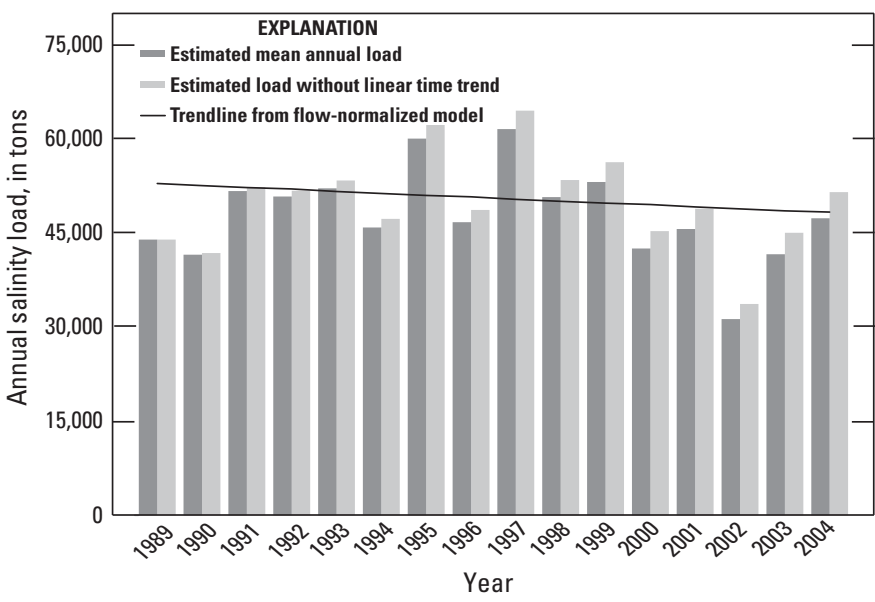

Figure 17. Estimated annual salinity load, annual salinity load had there been no time trend, and the trend line for the flow-normalized concentration and load at streamflow-gaging station 09146200 during water years 1989-2007.

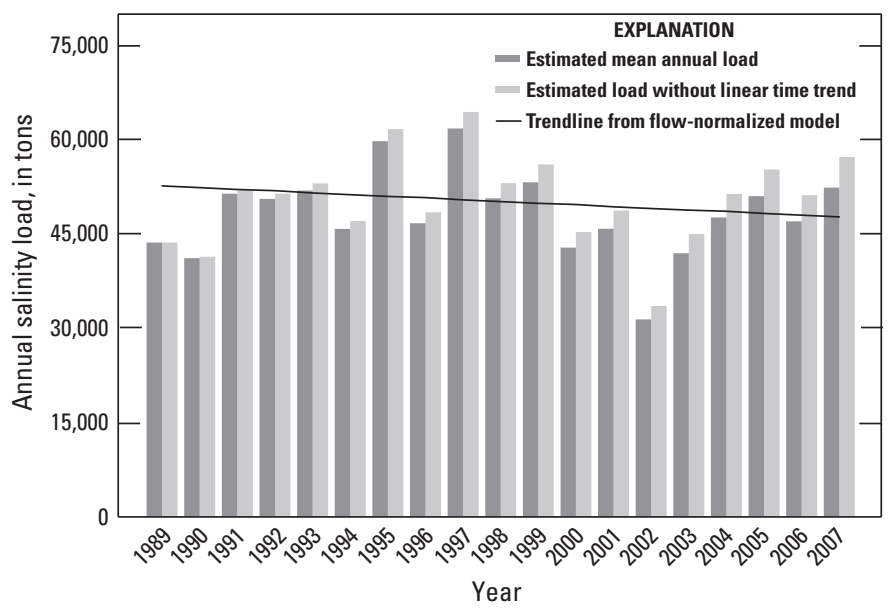

Figure 18. Estimated annual salinity load, annual salinity load had there been no time trend, and the trend line for the flownormalized concentration and load at streamflow-gaging station 09147025 during water years 1989-2004.

by 10 percent (table 5 ; fig. 18). The net decrease in flownormalized salinity load was 5,450 tons (95-percent CI -5,730 to $-5,180$ tons). The continued decrease between the two study periods indicates that the rate of decreasing flow-normalized salinity load remained steady through WY 2007.

Estimated mean annual salinity load at Uncompahgre River below Ridgway Reservoir, Colo. (streamflow-gaging station 09147025) was 66,500 tons. Annual flow-normalized salinity concentration and load significantly decreased $(\mathrm{p}=0.001$ ) by 9.7 percent during 1989-2004 (table 5; fig. 19). The net decrease in flow-normalized salinity load was 7,860 tons (95-percent $\mathrm{CI}-8,300$ to $-7,430$ tons). The quadratictime term was significant $(\mathrm{p}<0.001)$ and the minimum flownormalized salinity concentration and load occurred in WY 1997 (fig. 19). Flow-normalized salinity load in WY 1997 


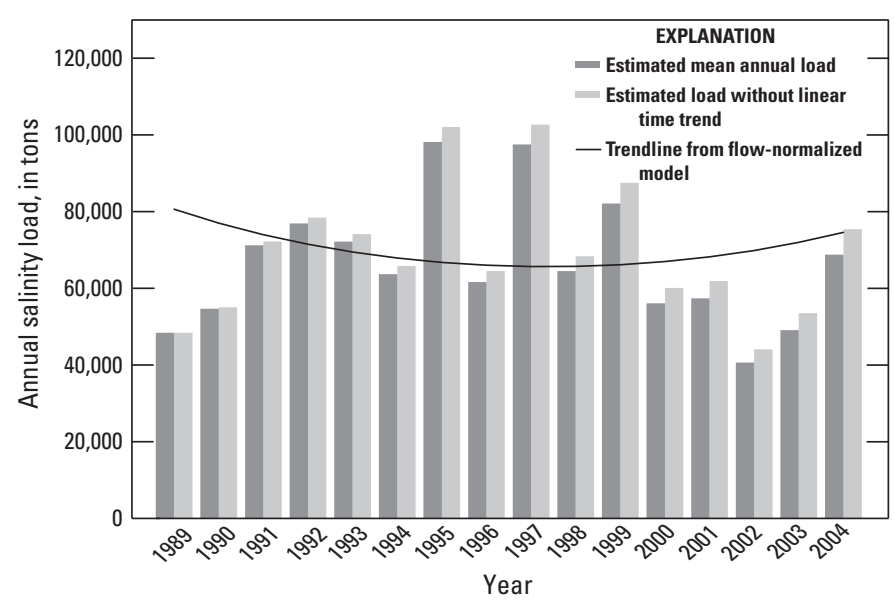

Figure 19. Estimated annual salinity load, annual salinity load had there been no time trend, and the trend line for the flownormalized concentration and load at streamflow-gaging station 09147500 during water years 1989-2004.

was 19 percent less than in WY 1989 and 12 percent less than in WY 2004. This site is located just downstream from Ridgway Reservoir and was a direct indication only of what is released from the reservoir. Therefore, the annual pattern at this site is not necessarily related to what is occurring in the overall watershed.

The site located on the Uncompahgre River at Colona, Colo. (streamflow-gaging station 09147500) is located upstream from where the Gunnison Tunnel enters the Uncompahgre River and dilutes salinity concentrations (Iorns and others, 1965). Estimated mean annual salinity load was 77,500 tons during 1989-2004. Annual flow-normalized salinity concentration and load significantly decreased $(\mathrm{p}=0.050)$ by 7.8 percent (table 5 ; fig. 20). The net decrease in flownormalized salinity loads was 7,160 tons (95-percent CI $-7,700$ to $-6,620$ tons). The quadratic-time term was significant $(\mathrm{p}=0.0005)$ and the minimum flow-normalized salinity load

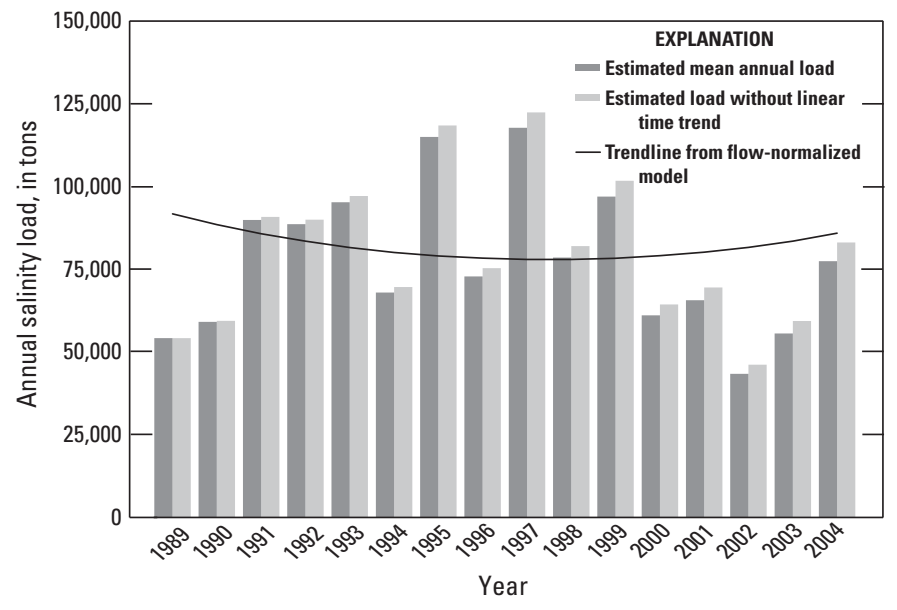

Figure 20. Estimated annual salinity load, annual salinity load had there been no time trend, and the trend line for the flownormalized concentration and load at streamflow-gaging station 09147500 during water years 1989-2004. occurred in WY 1997 (fig. 20). Flow-normalized salinity load in WY 1997 was 15 percent less than in WY 1989 and 9.2 percent less than in WY 2004. Both the overall decrease and the pattern of the decrease resembled the observed decreases of the next upstream site, Uncompahgre River below Ridgway Reservoir.

The Gunnison Tunnel (including South Canal) enters the Uncompahgre River about 3 river miles downstream from the Uncompahgre River at Colona site (fig. 3). The Gunnison Tunnel delivers approximately 320,000 acre-feet of water per year from the Gunnison River during the irrigation season (April through October) (Colorado's Decision Support Systems, 2004). For irrigated months (April through October) during the study period, the mean flow-normalized salinity concentration for the site downstream from the Gunnison Tunnel (streamflow-gaging station 09128000) was $116 \mathrm{mg} / \mathrm{L}$. This concentration is representative of the water that is delivered to the Uncompahgre River, assuming that the tunnel is not a source or a sink of salt to the water. The salinity concentration from the tunnel was 10 percent of the mean flow-normalized salinity concentration in the Uncompahgre River at Delta $(1,110 \mathrm{mg} / \mathrm{L})$ and 30 percent of the value from the upstream site, Uncompahgre River at Colona (387 mg/L). Based on estimates of streamflow (Colorado's Decision Support Systems, 2004) and concentration from the Gunnison River below Gunnison Tunnel site, the Gunnison Tunnel delivers about 50,000 tons of salt to the Uncompahgre River during the 7 months of the irrigation season. On average, this was 7,140 tons of salinity in 45,714 acre-feet of water per month from the tunnel. These estimates were based on the published delivery of water through the tunnel (Colorado's Decision Support Systems, 2004) applied to all years of the study period. Assuming there is no variability because of streamflow, these estimates are comparable to the flow-normalized estimates from the other sites.

The Uncompahgre River at Colona, Colo. (streamflowgaging station 09147500) is located upstream from the Gunnison Tunnel. Model results from the irrigated months only (April through October) indicated that mean flownormalized salinity load for the irrigated months was 9,520 tons in 21,600 acre-feet of water per month, which is 66,600 tons of salt during the 7-month period. Therefore, during 7 months of the irrigation season, the tunnel and the Uncompahgre River upstream from the tunnel contributed almost 117,000 tons of salt.

The most downstream site in subbasin 4 is located at the mouth of the Uncompahgre River, Uncompahgre River at Delta, Colo., (streamflow-gaging station 09149500) just before it enters the Gunnison River. In a previous study, mean annual salinity load at this site was 344,000 tons with a downward trend of 80,000 tons (about 22 percent) from WY 1959 to WY 1980 (Liebermann and others, 1989). In the current study, estimated mean annual salinity load was 281,000 tons during 1989-2004. Annual flow-normalized salinity concentration and load significantly decreased $(\mathrm{p}<0.001)$ by 17 percent (table 5; fig. 21). The net decrease in flow-normalized salinity load was 55,500 tons (95-percent CI $-56,800$ to $-54,200$ tons). 


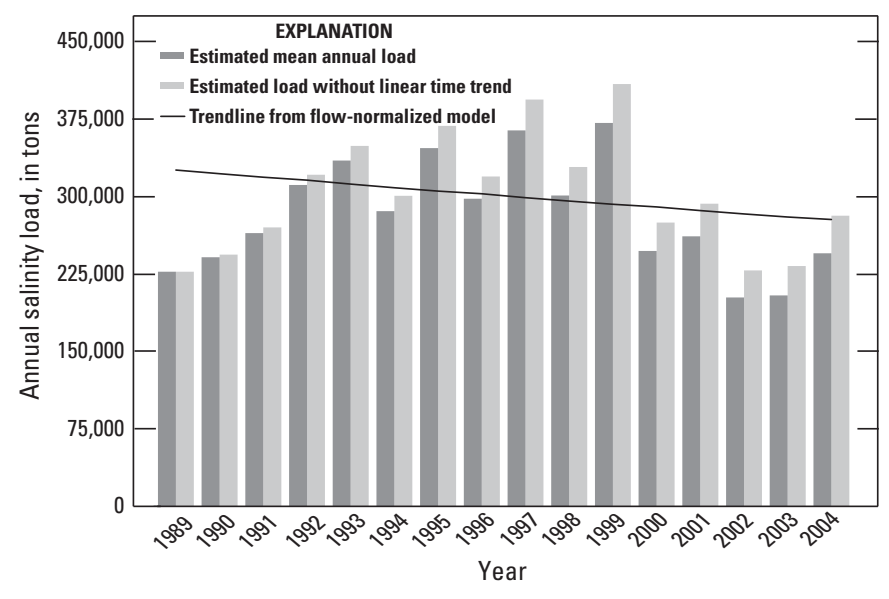

Figure 21. Estimated annual salinity load, annual salinity load had there been no time trend, and the trend line for the flownormalized concentration and load at streamflow-gaging station 09149500 during water years 1989-2004.

Estimated mean annual salinity concentration was $1,110 \mathrm{mg} / \mathrm{L}$ at this site, which is the highest of all of the sites in this study (table 5).

The results from Liebermann and others (1989) and this study imply that the downward trend in salinity has continued at nearly the same rate since 1959, though salinitycontrol projects were not implemented until 1988. More than 7,000 tons of the reduction in salinity loads can be attributed to the area above the next upstream site, Uncompahgre River at Colona, where a reduction of 7,160 tons was observed for the study period. The water delivered from the Gunnison Tunnel during the irrigation season with lower salinity concentrations dilutes the higher salinity water in the Uncompahgre River. Between the Gunnison Tunnel and the downstream site (Uncompahgre River at Delta) the river drains areas that are underlain by Mancos Shale and heavily irrigated (figs. 2 and 5) which would be expected to increase salinity loads. Increases in agriculture and irrigation on the Mancos Shale contribute significantly to increased salinity (Prairie and others, 2005; Kanzer and Merritt, 2008; Kenney and others, 2009), yet there still was a downward trend of 48,300 tons. Given that 48,300 tons is much more than any of the trends observed at the sites located in the higher elevation areas of subbasins 1 , 2 , and 3, which contain little to no irrigated agriculture, the majority of this decrease likely is most attributable to changes in land management in the form of salinity-control projects. Yet, the decrease documented by Liebermann and others (1989) was from a period prior to salinity-control projects. The reason for the decline was unknown although the authors stated that the decline may have been related to regulation and storage in Blue Mesa Reservoir which would have affected the water delivered to the Uncompahgre River by the Gunnison Tunnel (Liebermann and others, 1989). In this subbasin, $66 \mathrm{mi}^{2}$ of grassland land cover were converted to agriculture, forest, or urban land (Fry and others, 2009). In subbasins 1, 2, and 3 , the dominant land-cover change was the conversion of
$99 \mathrm{mi}^{2}$ of forested land to grassland. All of the sites in subbasin 4 are affected by irrigated agriculture and the majority of increased urbanization occurred between the Uncompahgre River at Colona , Colo. (streamflow-gaging station 09147500) and the Uncompahgre River at Delta, Colo. (streamflowgaging station 09149500).

\section{Subbasin 5}

The salinity load discharged from subbasin 5 represents the accumulation of salinity from the entire study area as it moves past the site on the Gunnison River near Grand Junction, Colo. (09152500). A previous study estimated that mean annual salinity load from WY 1966 to WY 1983 was 1,281,000 tons (Liebermann and others, 1989). In the current study, data were sufficient to analyze salinity trends during two study periods for this site. Estimated mean annual salinity load in this study was 1,031,000 tons during 1989-2004 and 1,039,000 tons during 1989-2007. Annual flow-normalized salinity concentration and load significantly decreased $(\mathrm{p}<0.001)$ by 21 percent during 1989-2004 (table 5; fig. 22). The net decrease in flow-normalized salinity load was 247,000 tons (95-percent CI -252,000 to $-241,000$ tons) (table 5). During 1989-2007, annual flow-normalized salinity concentration and load significantly decreased $(\mathrm{p}<0.001)$ by 17 percent (table 5; fig. 23). The net decrease in flownormalized salinity load was 207,000 tons (95-percent CI $-212,000$ to $-202,000$ tons). The difference in the decreases in flow-normalized concentrations between the two study periods is explained by the significance of the quadratic-time term in the 1989-2007 study period $(\mathrm{p}=0.003)$. The minimum flow-normalized salinity load occurred in WY 2002 (fig. 23) and flow-normalized salinity load in WY 2002 was 16 percent less than in WY 1989 and 2.5 percent less than in WY 2007. The modified-residual plot indicated that the flow-normalized

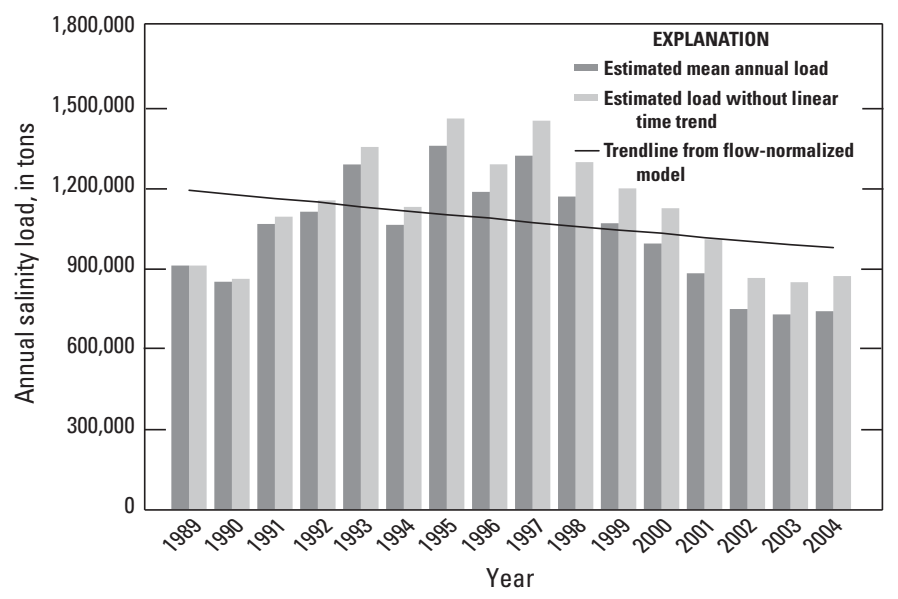

Figure 22. Estimated annual salinity load, annual salinity load had there been no time trend, and the trend line for the flownormalized concentration and load at streamflow-gaging station 09152500 during water years 1989-2004. 


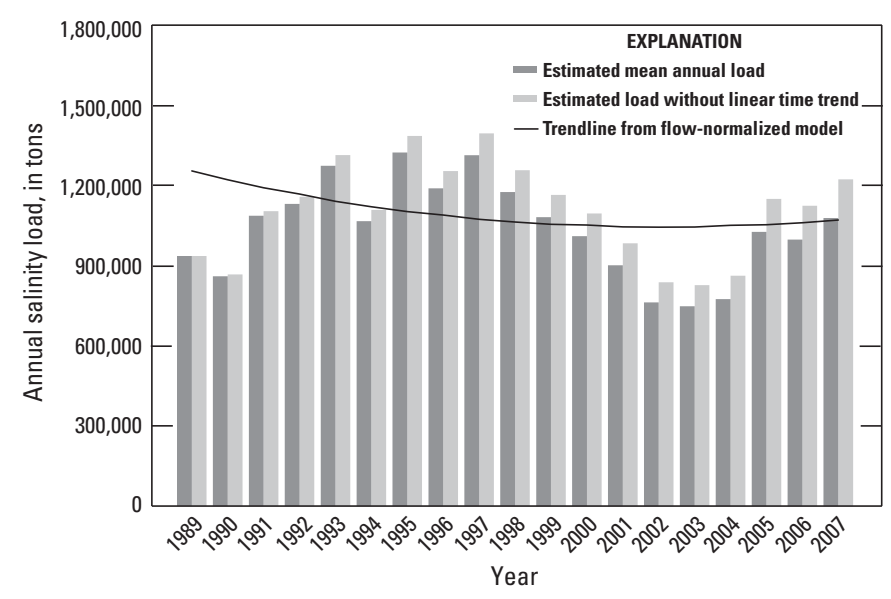

Figure 23. Estimated annual salinity load, annual salinity load had there been no time trend, and the trend line for the flownormalized concentration and load at streamflow-gaging station 09152500 during water years 1989-2007.

salinity concentration and load began to level out after the late 1990s. If the change in direction toward an upward trend (detected in the 1989-2007 study period) continues, it may be an indication that river quality was decreasing over time and that the reductions from salinity-control projects were slowing. The change in direction in the trend also may be an indication that salinity loads in the Gunnison River were leveling out and no longer changing over time. The latter explanation is more likely considering the modified-residual plot and that the increase from the minimum was only 2.5 percent. Additional years of salinity and streamflow monitoring of salinity would be needed to determine whether salinity load was increasing or leveling out in recent years.

The upstream sites in the study area provided an accounting of the portion of salinity load at the Gunnison River near Grand Junction that may be from the Upper Gunnison River Basin or urbanization. The Gunnison River below the Gunnison Tunnel is located at the mouth of the Upper Gunnison River Basin (fig. 2) and represents the salinity loads and trends from the Upper Gunnison River Basin. Estimated mean annual salinity loads during 1989-2004 were just 11 percent of those from the Gunnison River near Grand Junction (10 percent during 1989-2007). There also was no significant trend at the Gunnison River below the Gunnison Tunnel which indicated that the Upper Gunnison River Basin contributed little salinity and this contribution did not change during 1989-2004. The effects of urbanization are difficult to quantify because all of the sites that might be affected by increased urbanization also are affected by irrigated agriculture (figs. 2 and 3).

For 1989-2004, the sum of reduction from the upstream sites (Gunnison River and Uncompahgre River at Delta) was 234,000 tons which indicated that a reduction of about 13,000 tons of salinity occurred downstream from the sites near Delta, Colo. The majority of the tributaries are located on the southern side of the remainder of the watershed and they generally are underlain by Triassic-aged and older formations that are not known to contribute salinity. The Cretaceous-aged Dakota Sandstone and the Burro Canyon Formation crop out upslope from these tributaries and these two formations are known to contribute salt to streams, though less than the Mancos Shale (Day and Bove, 2003). However, there is little to no irrigated agriculture in these tributary drainages that would mobilize extra salts. On the north side of the Gunnison River, Kannah Creek flows through an irrigated area underlain by the Mancos Shale which is the likely source of additional salinity at the Gunnison River near Grand Junction site. The additional 13,000-ton reduction in salinity loads between Delta and Grand Junction could be attributed to salinity-control projects on Kannah Creek, land cover change, or to some other source not clearly identified by the analysis in this report.

\section{Nonagricultural Sources of Salinity}

Nonagricultural sources of salinity include municipal and domestic sources, and natural sources. Urbanization is an indicator of changes in municipal and domestic sources and many suggest that the portion of salinity loads from municipal and domestic sources is negligible (Iorns and others, 1965; Kenney and others, 2009). Natural sources of salinity are saline seeps and springs from geologic formations high in salt content as well as the weathering and dissolution of those same geologic formations.

For this study, six sites located in basins that were not affected by agricultural activity or urbanization were monitored to determine a natural salinity load from lower elevation areas in the Lower Gunnison River Basin. The sites were in crystalline (site SF1), sandstone (sites 25 Mesa, RCG1, and RCG2), and Mancos Shale (sites Hwy 50 and BKKM) geology (tables 1, 2, and 3).

Four of the six monitors functioned without issue for the duration of their operation. At the time of monitor installation, three of the sites (SF1, RCG1, and RCG2) had streamflow. The Smith Fork site (SF1) flows perennially and annual totals were determined from May 14, 2008 through May 14, 2009 (tables 3 and 6). Streamflow is characterized as ephemeral at the other two sites, RCG1 and RCG2, and is due to annual snowmelt patterns. Prior to the installation of the monitors, it is unknown when streamflow began at these two sites or how much water had passed by the sites. Streamflow ceased on May 25, 2008 at RCG1 and on May 20, 2008 at RCG2. No streamflow was observed at either site for the duration of the monitor operation (table 2). The totals represented only a portion of the annual streamflow and load for WY 2008 because there was no record of the initial snowmelt runoff for those two sites. Streamflow at the BKKM site is characterized as intermittent; the only streamflow at this site is the result of summer thunderstorms. Only one thunderstorm was detected at BKKM (table 3).

The monitor at the Hwy 50 site was in place from August 7, 2008 through August 10, 2010. During that time, 
the monitor malfunctioned four times. The first malfunction was for seven hours on October 9, 2008 and there was no apparent flow. The second malfunction was from October 9 through December 4, 2008 when the monitor recorded data at 15 -hour intervals instead of 15 -minute intervals. There was a small possibility that streamflow did occur during that period but based on lack of field evidence and the time of year, it was unlikely. The monitor was removed from the stream from December 4 through 16, 2008 and it was unlikely that streamflow occurred during that period. The fourth malfunction was periodic from July 29 through September 30, 2009; a large streamflow occurred during this period. Estimated streamflow of 31 cubic feet per second was calculated using indirect methods (Rantz and others, 1982; Phillips and Tadayon, 2006; Sturm, 2010). However, no specific-conductance or streamflow-duration data were obtained to calculate a salinity load for this storm. Based on field evidence, this streamflow occurrence was the only one missed because of monitor malfunction for any of the six natural sites.

The monitor at the 25 Mesa site was operational from September 11, 2008 through August 10, 2010. The monitor at the site malfunctioned twice during that period. The first malfunction occurred from November 17, 2008 through April 10, 2009 , and the second malfunction occurred from January 12 to
20,2010 . There was no field evidence to indicate that streamflow occurred during either of these periods. On May 27 and June 16, 2010, there were signs of recent streamflow that were not recorded by the monitor. Indications were that the flow was too small to reach the sensors.

All of the six natural sites are affected by annual or summer precipitation so precipitation data developed by the PRISM Climate Group (2004) were analyzed for five of the sites; the resolution of the PRISM data prevented analysis of precipitation at BKKM. PRISM data were available as monthly and annual totals for the period 1971-2000, and individual years 2008, 2009, and 2010. Annual totals from the period 1971-2000 were compared to those of the individual years during which the sites were in operation to determine whether it was a wet or dry year. Summer thunderstorm season was defined as July through October and those totals also were compared for the $25 \mathrm{Mesa}$ and Hwy 50 sites. These two sites were the most likely to be affected by summer thunderstorms.

Average annual precipitation for the period 1971-2000 decreased with elevation for the five sites analyzed (table 6). Average annual precipitation was 25.9 inches at site SF1, one of the higher elevation sites. At the lowest elevation site, Hwy 50, average annual precipitation was 11.5 inches (table 6). The lowest average annual precipitation was 9.56 inches at the

Table 6. Precipitation and salinity yield information for the selected natural sites, Gunnison River Basin, Colorado.

[--, data not collected; Thunderstorm season refers to July through October]

\begin{tabular}{|c|c|c|c|c|c|c|}
\hline $\begin{array}{c}\text { Short name, } \\
\text { figures } 1 \text { and } 5\end{array}$ & $\begin{array}{l}\text { Average annual } \\
\text { precipitation } \\
\text { (1971-2000), } \\
\text { in inches }\end{array}$ & $\begin{array}{l}\text { Annual } \\
\text { precipitation, } \\
\text { in inches }\end{array}$ & $\begin{array}{c}\text { Average } \\
\text { thunderstorm } \\
\text { season } \\
\text { precipitation } \\
\text { (1971-2000), } \\
\text { in inches }\end{array}$ & $\begin{array}{l}\text { Thunderstorm } \\
\text { season } \\
\text { precipitation, } \\
\text { in inches }\end{array}$ & $\begin{array}{l}\text { Annual } \\
\text { load, } \\
\text { in tons }\end{array}$ & $\begin{array}{c}\text { Annual } \\
\text { yield, } \\
\text { in tons per } \\
\text { square mile }\end{array}$ \\
\hline \multicolumn{7}{|c|}{2008} \\
\hline BKKM & 12.4 & -- & -- & -- & 27.9 & 71.5 \\
\hline RCG1 & 16.6 & 15.5 & 6.44 & 4.49 & ${ }^{1} 4.94$ & ${ }^{1} 1.08$ \\
\hline RCG2 & 16.1 & 15.4 & 6.23 & 4.58 & ${ }^{1} 0.28$ & ${ }^{1} 0.03$ \\
\hline SF1 & 25.9 & 28.2 & 8.24 & 5.80 & ${ }^{2} 3,080$ & 71.0 \\
\hline \multicolumn{7}{|c|}{2009} \\
\hline 25 Mesa & 9.56 & 6.06 & 4.01 & 1.30 & 0.53 & 0.55 \\
\hline BKKM & 12.4 & -- & -- & -- & 0 & 0 \\
\hline Hwy 50 & 11.5 & 8.79 & 4.46 & 2.00 & 0.01 & 0.001 \\
\hline RCG1 & 16.6 & 14.4 & 6.44 & 4.17 & 0 & 0 \\
\hline RCG2 & 16.1 & 14.4 & 6.23 & 4.21 & 0 & 0 \\
\hline SF1 & 25.9 & 22.7 & 8.24 & 5.52 & -- & -- \\
\hline \multicolumn{7}{|c|}{2010} \\
\hline 25 Mesa & 9.56 & 8.64 & 4.01 & 4.28 & 3.07 & 3.20 \\
\hline Hwy 50 & 11.5 & 11.6 & 4.46 & 5.00 & 54.0 & 5.97 \\
\hline
\end{tabular}

${ }^{1}$ Values for these two sites are actually from April through September only. There were not sufficient data to include the remaining months.

${ }^{2}$ Annual load for 2008 was calculated for May 15, 2008 through May 14, 2009. 
25 Mesa site. In 2008, annual precipitation at SF1 was 109 percent of the average. At RCG1 and RCG2, annual precipitation for 2008 was slightly less than average: 93 percent and 96 percent, respectively. In 2009, precipitation at all sites was below average ranging from 63 percent of the average at 25 Mesa to 89 percent of average at RCG2. In 2010, precipitation at 25 Mesa was 90 percent of the average and precipitation at Hwy 50 was 101 percent of the average. These results indicated that, of the years analyzed, 2009 was a relatively dry year and 2008 and 2010 were near average (PRISM Climate Group, 2004).

At sites characterized by intermittent streamflow (BKKM, Hwy 50, and 25 Mesa), all but two streamflows occurred during the thunderstorm season between July and October (table 3 ). The streamflow occurrences that were outside of this period occurred on June 2nd and 25th, 2009 at the 25 Mesa site (table 3). In 2009, precipitation from the thunderstorm season was less than 50 percent of the average for the Hwy 50 and 25 Mesa sites. In 2010, thunderstorm season precipitation was 112 percent of average at Hwy 50 and 107 percent of average at 25 Mesa (PRISM Climate Group, 2004). These data support the conclusion that 2009 was relatively dry and 2010 was near average, or possibly wetter than average for Hwy 50 and 25 Mesa.

The year 2008 was considered an average year for precipitation at the operating natural sites and salinity yield and loads were directly related to geology and streamflow patterns. Salinity yields ranged from $0.03 \mathrm{ton} / \mathrm{mi}^{2}$ at RCG2 to $71.5 \mathrm{ton} / \mathrm{mi}^{2}$ at BKKM. RCG2 represents the larger of the two areas and is underlain by sandstone while BKKM represents an area underlain by Mancos Shale (table 6). The yield at site SF1was 71.0 ton $/ \mathrm{mi}^{2}$ and at least 65 percent of the yield (46.2 ton $/ \mathrm{mi}^{2}$ ) was attributed to the crystalline geology within the basin. In 2008, the highest annual load was measured at $\mathrm{SF} 1$ at 3,080 tons and was attributable to the perennial flow at this site. The salinity load from the sandstone sites, characterized by ephemeral flow, ranged from 0.28 tons at RCG2 up to 4.94 tons at RCG1 (table 6). The annual load from sites RCG1 and RCG2 only represents a portion of the period of streamflow for these locations when operation of these sites began. The annual load in 2008 from the site dominated by Mancos Shale (BKKM) and characterized by intermittent flow was 27.9 tons (table 6). Total load measured from the natural sites was 3,110 tons and 99 percent of the load was from site SF1 characterized by perennial flow and located at a higher elevation (7,095 feet above sea level) (table 1). Using a spatially referenced statistical assessment of salinity, Kenney and others (2009) estimated an annual load of 2,380 tons in 1991 at SF1 (reach 4621 in Kenney and others, 2009). Water year 1991 was chosen because it was hydrologically near normal in terms of average streamflow conditions and the 30 -year average precipitation (Kenney and others, 2009).

The following year, 2009, was a dry year by comparison with the average precipitation from 1971 to 2000 . This is reflected in the annual loads and yields from the sites operating in 2009. Streamflow did not occur at BKKM, RCG1, or
RCG2 and therefore, loads and yields were zero. However, those three sites were operated only through June 9, or July 31, 2009 (table 2). Streamflow was first detected on June 25, 2009 at 25 Mesa and 2 months later on August 25, 2009 at Hwy 50 (table 3). Annual yield at 25 Mesa from 4 streamflow occurrences in 2009 was $0.55 \mathrm{ton} / \mathrm{mi}^{2}$ and the annual load was 3.87 tons. At Hwy 50, annual yield from two streamflow occurrences was $0.001 \mathrm{ton} / \mathrm{mi}^{2}$ and annual load was 0.01 tons (table 6).

Two sites were monitored in 2010 and both had two streamflow occurrences. At the 25 Mesa site, the annual yield was 3.20 ton $/ \mathrm{mi}^{2}$ and annual load was 3.07 tons. At the Hwy 50 site, the annual yield was $5.97 \mathrm{ton} / \mathrm{mi}^{2}$ and annual load was 54.1 tons.

Summer precipitation in Colorado is characterized by convective storms with high spatial variability in the amount and intensity of rainfall. This was especially evident in the differences between the streamflows detected at the two monitors on August 4, 2010. Peak streamflow at the 25 Mesa site was estimated at $600 \mathrm{ft}^{3} / \mathrm{s}$ which equated to the largest streamflow of the period of operation. At the Hwy 50 site, the peak streamflow only was $0.4 \mathrm{ft}^{3} / \mathrm{s}$ for that same date. The largest streamflow of the period of operation at Hwy 50 occurred on July 28, 2010 and streamflow was not detected at the 25 Mesa site on that date. These results demonstrate that, for a given storm, not every intermittent tributary flows and estimation of a total salinity load from the intermittent tributaries was difficult.

Salinity concentrations are related to the underlying geology, so the yields calculated from the natural sites were used to calculate a natural salinity load for the entire Gunnison River Basin based on geology. The total area underlain by Mancos Shale (about 14 percent) was multiplied by the yield from BKKM in WY 2008 and the yield from Hwy 50 in WY 2009 and WY 2010 to estimate load from the area underlain by Mancos Shale. The area underlain by sandstone, 18 percent, was multiplied by the yield from RCG2 in WY 2008 and 25 Mesa in WY 2009 and WY 2010 to estimate the load from areas underlain by sandstone. Sandstone formations included the Jurassic-aged Morrison, Entrada, and Wanakah formations, and the Cretaceous-aged Dakota Sandstone, and Burro Canyon formations. Finally, the area associated with the remainder of the formations, 68 percent, was multiplied by the crystalline yield obtained from SF1 for all 3 years to estimate load from areas underlain by crystalline geology. For each year, the loads estimated based on the yields from the natural sites were summed for an estimate of the load for the study area that was attributable to geology without the effect of irrigation. The natural salinity loads were compared to the estimated mean annual load calculated for the Gunnison River near Grand Junction, Colo. (streamflow-gaging station 09152500) during 1989-2007. Using the range of yield (46-71 ton $\left./ \mathrm{mi}^{2}\right)$ for the crystalline geology, natural salinity load was $47-63$ percent, 29-45 percent, and 31-47 percent of the mean annual load at the Gunnison River near Grand Junction for WY 2008, 2009, and 2010, respectively. 
Two earlier studies documented salt loading from natural sources in the Gunnison River at the site near Grand Junction (streamflow-gaging station 09152500). One study found that the natural component of the salinity load was 542,000 tons per year from WY 1914-1957, assuming the 1957 level of water-resources development (Iorns and others, 1965). Mean annual salinity load for that period was $1,519,000$ tons, so the natural component was about 36 percent of the total (Iorns and others, 1965). For the same study period, another study used a mass-balance approach to adjust the results reported in Iorns and others (1965) and found that 431,000 to 463,000 tons of salinity were because of natural sources and the mean annual salinity load was 1,330,000 tons (Mueller and Osen, 1988). This indicated that as much as 35 percent of the salinity load was from natural sources. A third study used a spatially referenced statistical assessment tool and found that 32 percent of the total load at the Gunnison River near Grand Junction was associated with nonagricultural sources (Kenney and others, 2009). Estimates from all three studies fell within the range estimated for the entire Gunnison River Basin in this report.

The calculations for the natural component of salinity load in the entire Gunnison River Basin indicate that natural salinity load was as high as 63 percent but possibly as low as 29 percent of the total at the Gunnison River near Grand Junction. Previous studies found that natural load in the Gunnison River Basin ranged from 32 percent up to 36 percent (Iorns and others, 1965; Mueller and Osen, 1988; Kenney and others, 2009). Consideration of the entire basin included perennially flowing sites at high elevations and included the portion of the basin that has very little agricultural activity (fig. 2). While the higher elevations contributed a portion of the natural salinity load, this study has shown that there were no trends over time (either study period) at the higher elevation sites of the Upper Gunnison River Basin, based on the results for the Gunnison River near the Gunnison Tunnel, Colo. (streamflow-gaging station 09128000). The higher elevation sites in subbasin 3 North Fork of the Gunnison River near Somerset, Minnesota Creek near Paonia, and the two sites on Surface Creek-did not have a consistent pattern in the trend direction. This indicated that, generally, sites with little to no agriculture in their basins do not show a consistent trend in salinity concentration and load. Considering only the Lower Gunnison River Basin (below the Gunnison Tunnel), which includes some higherelevation areas in the Uncompahgre River and North Fork of the Gunnison watersheds, the natural component of salinity loads ranged from 20-26 percent, 13-19 percent, and 1420 percent of the mean annual load at the Gunnison River near Grand Junction for WY 2008, 2009, and 2010, respectively. Natural sources contributed a small percentage of the load in the lower elevation areas and the sites identified in this report located in basins with little to no irrigated agriculture did not have a consistent pattern in the significant trends.

\section{Factors Affecting Salinity}

Salinity in surface water in the Gunnison River Basin is potentially affected by climatic patterns, land-use change including urbanization, and irrigation. Most of the effect of climate on salinity trends in the basin was removed by accounting for the variability in salinity resulting from variability in streamflow. In the late 1990s there was a shift in the direction of the trend for many of the higher elevation sites in the study area. However, the shift direction was not consistent. In subbasin 2 and the higher elevation areas of subbasin 4, trends in salinity were downward from 1989 until the late 1990s and then were upward. In the higher elevation areas of subbasin 3, salinity trends generally were upward from 1989 until the late 1990s and then were downward. This may be explained by the conversion of land between forest and grassland that was seen throughout the basin. Results from the natural sites indicated that the natural component of salinity loads ranged from 29 to 63 percent and the majority of that was from areas with little to no irrigated agriculture characterized by crystalline geology, high elevations, and perennial flow. The findings of this study agree with previous studies (Iorns and others, 1965; Mueller and Osen, 1988) that there was no trend in the natural component of salinity load in the Gunnison River Basin.

The salinity trend sites, where the effects of urbanization might be observed, are in subbasins 1 and 2. In subbasins 3, 4 , and 5 the effects of urbanization would be confounded by the irrigated agriculture also in those subbasins. Increased urbanization is expected to result in less land affected by irrigated agriculture and therefore, a decrease in salinity (Mayo, 2008). However, when forested land or grassland is converted to urban land, it is possible that an increase in salinity could be observed. At the Gunnison River below the Gunnison Tunnel there was no significant trend during either 1989-2004 or 1989-2007. This indicated that either the effect of urbanization upstream was attenuated by the Aspinall Unit or there was no observable effect over time. Salinity loads did increase during 1989-2007 in subbasin 1 as shown by the trend results at the Gunnison River near Gunnison. The increases could be the result of increased urban land, though the most likely explanation for the increase in salinity at this site was the irrigated agriculture in the subbasin, and that a portion of the irrigated land is underlain by Mancos Shale. There also was an increase in salinity loads observed at the Lake Fork at Gateview site (subbasin 2). The increases at this site most likely were the result of changes in land cover as there is little to no irrigated agriculture in the drainage area and the urban area (Lake City) had a population of 375 that did not change between 2000 and 2010 (U.S. Census Bureau, 2010).

The largest changes in salinity load occurred at the Gunnison River near Grand Junction, Gunnison River at Delta, and the Uncompahgre River at Delta sites; the three sites are the most affected by irrigated agriculture. Irrigated acreage, especially acreage underlain by Mancos Shale, is the target of salinity-control projects intended to decrease salinity loads. 
The USBR and the NRCS have sponsored the majority of salinity control work in the Lower Gunnison Unit. The Lower Gunnison Unit encompasses the irrigated farmland in the North Fork of the Gunnison River (subbasin 3) and Uncompahgre River valleys (subbasin 4) and irrigated areas north and east of Delta along the Gunnison River (Leib and Bauch, 2008; Bureau of Reclamation, 2009, 2010). The USBR implements projects off-farm while the NRCS works on-farm. Each agency has provided their internal estimates of salinity reduction as a result of the controls they have implemented, which can be compared with the flow-normalized estimate of salinity reduction at the Gunnison River near Grand Junction presented in this report. This comparison assumed that the reductions estimated by the USBR and NRCS actually were achieved in the river. Also, the level of uncertainty or error in the estimates is unknown.

By 2004, the USBR had lined 8.5 miles of canals in Montrose Arroyo which is just downstream from the South Canal and flows through Montrose in the Uncompahgre River Basin (subbasin 4) (fig. 3). The USBR also had eliminated stock-watering areas by making domestic water available to fill stock-water tanks (Mike Baker, Bureau of Reclamation, written commun., September 20, 2010; Bureau of Reclamation, 2010). As of 2004, USBR estimated salinity reductions totaled 43,600 tons; 2,300 tons of reduction were from canal lining and 41,300 tons of reduction were from eliminating stock-watering areas. Between 2004 and 2007, the USBR began phase 2 of the salinity control improvements. Canal lining in additional drainages resulted in 5,920 tons of salt reduction by 2007 so estimates of salinity reduction as of 2007 totaled 49,520 tons (Mike Baker, Bureau of Reclamation, written commun., September 20, 2010).

The NRCS estimated that, on-farm and small irrigation ditch improvements implemented on $60.5 \mathrm{mi}^{2}$ of land resulted in a cumulative reduction of 73,700 tons of salinity as of 2004 (Frank Riggle, Natural Resources Conservation Service, written commun., July 28, 2010). By 2007, the NRCS improvements were implemented on an additional $15.5 \mathrm{mi}^{2}$ of land, and cumulative reduction estimates increased to 92,500 tons.

According to the estimates from the USBR and NRCS, salinity-control projects may be responsible for a reduction of 117,300 tons of salinity as of 2004 and 142,000 tons as of 2007 at the Gunnison River near Grand Junction, Colo. (streamflow-gaging station 09152500). This means that about 130,000 tons of reduction in salinity load by 2004 at the Gunnison River near Grand Junction were reduced that remain unexplained. Trend analysis indicated that by 2007 flownormalized loads had decreased 207,000 tons. Estimates from the USBR and NRCS account for all but 65,000 tons of that reduction. The additional reduction could be a reduction in salt loading as a result of changing land cover during the study periods. Little is known of the effects of conversion of forested land to grassland on salinity loads. The NLCD Change Product (Fry and others, 2009) indicated large changes in land cover throughout the basin that may be an explanation for the changes in salinity load. Another possibility is that the USBR and NRCS have underestimated changes in salinity loads as a result of the implementation of salinity-control projects. Aside from the canal lining on Montrose Arroyo, exact locations of projects are unknown. Additional information on the specific locations of projects would allow for a more detailed analysis of salt reduction in each basin. With an understanding of specific project locations and estimates from those locations, those estimates could be compared to adjacent basins where there have been no salinity-control projects. Also, continued monitoring of the natural sites is essential to an understanding of the natural contribution of salinity in lower elevation areas characterized by intermittent flow from convective summer thunderstorms.

\section{Summary and Conclusions}

Elevated levels of dissolved solids in water (salinity) can result in numerous and costly issues for agricultural, industrial, and municipal water users and managers. Irrigation of agricultural lands, particularly those lands underlain by the sedimentary bedrock associated with salt loading, is the major anthropogenic source of salinity. The Colorado River Basin Salinity Control Act (Public Law 93-320), enacted in 1974 in response to the elevated salinity in the Lower Colorado River Basin, authorized the Department of the Interior, acting through the Bureau of Reclamation, to construct and plan salinity-control projects in the Colorado River Basin. One of the first projects was the Lower Gunnison Unit, a project to mitigate salinity that began in the Lower Gunnison and Uncompahgre River Basins in 1988.

To understand the effects of salinity-control projects and land-use changes, the USGS, in cooperation with the U.S. Bureau of Reclamation, quantified changes in salinity in the Gunnison River and other rivers and streams in the Gunnison River Basin during water years (WY) 1989 through 2007 in order to understand the effects of salinity-control projects and land-use change. Trends in salinity loads during the period (WY) 1989 through 2004 (1989-2004) were determined for 15 selected streamflow-gaging stations in the Gunnison River Basin. Additionally, trends in salinity loads during the period WY 1989 through 2007 (1989-2007) were determined for 5 of the 15 sites for which sufficient data were available. Trend results also were used to identify regions in the Lower Gunnison River Basin where the largest changes in salinity loads occur. Additional sources of salinity, including residential development (urbanization), changes in land cover, and natural sources, were estimated within the context of the trend results. The trend results and salinity loads estimated from trends testing also were compared to USBR and NRCS estimates of off-farm and on-farm salinity reduction from salinity-control projects in the basin.

Twenty-one sites in the Gunnison River Basin were selected to meet the objectives of this study. Six sites were selected for this study to represent the salinity loads from areas 
that are not affected by agriculture and irrigation, referred to as "natural sites." The remaining 15 sites were chosen based on availability of data to measure the trends in salinity during 1989-2004 and are "salinity trend sites." The 1989-2004 study period was chosen because the Natural Resources Conservation Service began applying improved irrigation systems and practices with cooperators in the study area beginning in 1988. Five of the sites also had sufficient data to determine salinity loads during 1989-2007.

Salinity loads were calculated using a U.S. Geological Survey statistical program, S-LOADEST (LOAD ESTimation). The regression model equations provided by S-LOADEST (a plug in to the S+ statistical software package) were used to estimate daily loads and determine significance, magnitude, and direction of any existing time trend. Previous studies calculated loads and then tested trends separately using a method referred to as "regression on residuals." In this study, a method "normalized regression" was compared with the regression on residuals method to provide a context for the results in this study to those in the previous studies.

Using the regression on residuals method for the Gunnison River near Grand Junction site, salinity decreased during $1989-2004$ by 164,000 tons, or 16 percent $(\mathrm{p}<0.001)$. The decrease in load using the normalized regression method documented in this study was 247,000 tons or 21 percent during the 16-year period $(\mathrm{p}<0.001)$. For the 1989-2007 study period, the regression on residuals method estimated a decrease of 153,000 tons and the normalized regression method estimated a decrease of 207,000. And for the 1986-2003 study period, the regression on residuals method estimated a decrease of 202,000 tons and the normalized regression method estimated a decrease of 273,000 tons. Based on these comparisons, the regression on residuals method underestimates changes in salinity load in the study area relative to the normalized regression method documented in this study. This finding is supported by a study which found that normalized regression has more power and fewer errors relative to the regression on residuals method. The normalized regression method was chosen to evaluate trends in salinity concentration and load for this report.

The 15 salinity trend sites in this study were divided among five subbasins that correspond to four sites on the Gunnison River and one site on the Uncompahgre River just before it enters the Gunnison River. The site located in the uppermost subbasin (subbasin 1) of the study area is the Gunnison River near Gunnison (streamflow-gaging station 09114500) where estimated mean annual salinity load was 72,400 tons. Salinity loads did not change significantly during water years 1989-2004 though there was a significant increase of 3.9 percent (2,890 tons) during 1989-2007.

The Gunnison River below Gunnison Tunnel (streamflow-gaging station 09128000), located at the mouth of subbasin 2, had an estimated mean annual salinity load of 110,000 tons during 1989-2004. Analysis of both study periods (1989-2004 and 1989-2007) showed an initial decrease in salinity load with a minimum in 1997 . The net change over either study period was only significant during 1989-2007. Most of the underlying geology in subbasin 2 is of relatively low salt content. Particularly, the Lake Fork and the Cimarron River are located in areas underlain by Tertiary volcanics and are indicative of the lower end of the range of natural salinity concentrations. However, throughout subbasin 2, the irrigated land is underlain by Quaternary-aged deposits and Mancos Shale. Urbanization and land-use changes are a potential explanation for the observed changes in salinity but urbanized areas generally are located near the majority of irrigated acreage so it was difficult to determine whether increased urbanization had an effect on salinity loads.

Subbasin 3 refers to the area upstream from the site located on the Gunnison River at Delta (streamflow-gaging station 09144250) and includes subbasins 1 and 2 as well as four additional sites in the northern part of the study area and the site on the Gunnison River near Delta. The four sites in the northern portion of the study area are located in the upper reaches of the subbasin and have little to no irrigated agriculture in their drainage areas.

The majority of the tributary basins near Delta, Colo. are underlain by Mancos Shale formations capped by Quaternaryaged gravel and alluvium. At the Gunnison River near Delta, estimated mean annual salinity load was 577,000 tons during the 1989-2004 period and salinity loads decreased a total of 179,000 tons during the period $(\mathrm{p}<0.001)$. Salinity loads from the upstream sites in the subbasin that were included in the study have downward trends that, as of 2004, indicate a cumulative increase of 4,030 tons of salinity since the mid1990's, though during 1989-2004, there was a net increase of 1,500 tons. Also in the 1989-2004 period, salinity loads in the Gunnison River below the Gunnison Tunnel did not change significantly. At least a portion of this decrease can be explained by decreased irrigated acreage from 1993 to 2000 and increased use of sprinklers for irrigation. The largest landcover change was a conversion of 47 square miles of forested land to grassland and this may be an additional explanation for the salinity trends.

The Uncompahgre River enters the Gunnison River just downstream from Delta at the site located at the Uncompahgre River at Delta (streamflow-gaging station 09149500). Estimated mean annual salinity load for 1989-2004 was 281,000 tons at this site. Estimated concentration was highest at this site. During 1989-2004, salinity loads decreased by more than 55,500 tons. More than 7,000 tons of this reduction can be attributed to the area above the next upstream site, Uncompahgre River at Colona, where a reduction of 7,160 tons was observed for the study period. The water delivered by the Gunnison Tunnel likely dilutes the water in the Uncompahgre River during irrigation season and contributes to the reduction in salinity concentrations. Although urbanization in the area increased, the land that was converted to an urban land cover was previously grassland so it is unlikely that urbanization is an explanation for the salinity reduction. The urbanized areas also are near irrigated agriculture, so it is difficult to differentiate the effect of increased urbanization. An overall increase in 
agricultural land cover between 1992 and 2001 corresponds with an increase in irrigated square miles between 1993 and 2000. The irrigated land almost is completely underlain by Mancos Shale capped with Quaternary-aged gravels and alluvium. Increases in agriculture and irrigation on the Mancos Shale significantly contribute to increased salinity, yet there was still a decrease in salinity load of 48,300 tons.

The final subbasin represents the entire basin and all sites with the most downstream site Gunnison River near Grand Junction (09152500). Estimated mean annual salinity load at this site was 1,031,000 tons during 1989-2004 study period and 1,039,000 during 1989-2007 study period. Salinity loads significantly decreased 247,000 tons during 1989-2004 and 207,000 tons during 1989-2007. The analysis from the later study period indicates that the decreases in salinity loads are leveling out over time. The reduction observed at the Gunnison River at Delta summed with the reduction observed at the Uncompahgre River at Delta total 234,000 tons for 19892004, which indicated that a reduction of about 13,000 tons of salinity occurred downstream from the sites near Delta, Colo. This reduction could be attributed to either salinity-control activities in the Kannah Creek area or a reduction in salinity because of land cover changes.

Six sites that were unaffected by agriculture were analyzed to determine the natural component of salinity load in the Gunnison River Basin. The monitors in operation at the six sites successfully recorded all but one streamflow occurrence during the period of monitor operation. Precipitation records indicate of the 3 years that monitors were in operation, 2008 and 2010 were within 10 percent of the average annual precipitation and 2009 was below average. Three of the sites are characterized by intermittent flow. The higher elevation sites were characterized by either perennial or ephemeral (snowmelt) streamflow. The sites characterized by intermittent flow have streamflow as a result of convective thunderstorms that have high spatial variability in the amount and intensity of rainfall which results in high spatial variability in the amount of salinity load.

Annual load contributed from the natural sites monitored was related to geology and streamflow patterns. The site characterized by perennial flow and crystalline geology had a salinity load of 3,080 tons in 2008 , which was the highest salinity load from the natural sites. The sandstone sites (ephemeral and intermittent) had annual loads less than 5 tons in 2008, 0.53 tons in 2009, and 3.1 tons in 2009. Annual load from the sites dominated by Mancos Shale was 27.9 tons in
2008 (BKKM), 0.01 tons in 2009 (Hwy 50), and 54 tons in 2010 (Hwy 50). Based on the calculated yields and geology, 29-63 percent of the estimated annual salinity load at the Gunnison River near Grand Junction during 1989-2007 was from natural sources. However, this includes perennially flowing high-elevation sites. The majority of agriculture is in lower elevations characterized by intermittent or ephemeral streamflow. Natural sources contribute a smaller percentage of the load in the lower elevation areas (13-26 percent).

The trend results presented in this study indicate that the effect of urbanization on salinity loads is negligible, though difficult to determine. The largest changes in salinity load occurred at the Gunnison River near Grand Junction and at the two sites located in Delta: the Gunnison River at Delta and the Uncompahgre River at Delta. Those three sites, especially the two sites at Delta, are the most affected by irrigated agriculture, which is observed in the estimated mean annual loads. Irrigated acreage, especially acreage underlain by Mancos Shale, is the target of salinity-control projects intended to decrease salinity loads.

The Bureau of Reclamation and Natural Resources Conservation Service have done the majority of salinity control work in the Lower Gunnison area of the Gunnison River Basin, and the focus has been on the Uncompahgre River Basin and portions of the Gunnison River Basin near Delta. According to the estimates from the Bureau of Reclamation and Natural Resources Conservation Service, salinity-control projects may be responsible for a reduction of 117,300 tons of salinity as of 2004 and 142,000 tons as of 2007 at the Gunnison River near Grand Junction (streamflow-gaging station 09152500). This means that 130,000 tons of reduction in salinity load by 2004 at the Gunnison River near Grand Junction remain unexplained. By 2007, flow-normalized loads had decreased 207,000 tons and estimates from the Bureau of Reclamation and Natural Resources Conservation Service account for all but 65,000 of that reduction. Aside from the canal lining on Montrose Arroyo, exact locations of projects are unknown. Additional information on the specific locations of projects would allow for a more detailed analysis of salt reduction in each basin. The additional reduction could be a reduction in natural salt loading to the streams because of land-cover changes during the study period. It is possible also that the Bureau of Reclamation and Natural Resources Conservation Service have underestimated changes in salinity loads as a result of the implementation of salinity-control projects. 


\section{References Cited}

Alley, W.M., 1988, Using exogenous variables in testing for monotonic trends in hydrologic time series: Water Resources Research, v. 24, no. 11, p. 1955-1961.

Anning, D.W., Bauch, N.J., Gerner, S.J., Flynn, M.E., Hamlin, S.N., Moore, S.J., Schaefer, D.H., Anderholm, S.K., and Spangler, L.E., 2007, revised 2010, Dissolved solids in basin-fill aquifers and streams in the Southwestern United States: U.S. Geological Survey Scientific Investigations Report 2006-5315, v.1.1, 168 p.

Brooks, Tom, and Ackerman, D.J., 1985, Reconnaissance of ground-water resources in the Lower Gunnison River Basin, southwestern Colorado: U.S. Geological Survey WaterResources Investigations Report 84-4185, 35 p.

Bureau of Land Management, 2009, Bureau of Land Management Colorado state wide geospatial database, 1st conflated poly: Bureau of Land Management, Colorado State Office, Geosciences Team, Dave Taylor (ed.).

Bureau of Reclamation, 2009, Colorado River Basin salinity control program federal accomplishments report for fiscal year 2009, accessed August 13, 2010, available online at http://www.usbr.gov/uc/progact/salinity/pdfs/ FedAccompRep-2009.pdf.

Bureau of Reclamation, 2010, Colorado River Basin Salinity Control Program- Lower Gunnison Basin Unit- Title II, accessed August 13, 2010, available online at http://www. usbr.gov/projects/Project.jsp? proj_Name $=C R B S C P+-$ + Lower+Gunnison+Basin+Unit+-+Title+II.

Butler, D.L., 1996, Trend analysis of selected water-quality data associated with salinity-control projects in the Grand Valley, in the Lower Gunnison River Basin, and at Meeker Dome, western Colorado: U.S. Geological Survey WaterResources Investigations Report 95-4274, 38 p.

Butler, D.L., and von Guerard, P.B., 1996, Salinity in the Colorado River in the Grand Valley, western Colorado, 1994-95: U.S. Geological Survey Fact Sheet FS-215-96, $4 \mathrm{p}$.

Cleveland, W.S., 1985, The elements of graphing data: Monterey, Calif., Wadsworth Books, 323 p.

Cleveland, W.S., and R. McGill, 1984b, The many faces of a scatterplot: Journal of the American Statistical Association, no. 79 , p. $807-822$.

Cohn, T.A., DeLong, L.L., Gilroy, E.J., Hirsch, R.M., and Wells, D.K., 1989, Estimating constituent loads: Water Resources Research, v. 25, no. 5, p. 937-942.
Cohn, T.A., Caulder, D.L., Gilroy, E.J., Zynjuk, L.D., and Summers, R.M., 1992, The validity of a simple statistical model for estimating fluvial constituent loads: An empirical study involving nutrient loads entering Chesapeake Bay: Water Resources Research, v. 28, no. 9, p. 2353-2364.

Colorado's Decision Support Systems, 2004, Gunnison River Basin information: Colorado Division of Water Resources, available online at: $f t p: / / d w r f t p . s t a t e . c o . u s / c d s s / s w m / i n /$ GunnisonInfo_200407.pdf.

Crawford, C.G., 1996, Estimating mean constituent loads in rivers by the rating-curve and flow-duration rating-curve methods: Bloomington, Indiana, Indiana University, Ph.D. dissertation, $245 \mathrm{p}$.

Day, W.C., and Bove, D.J., 2003, Review of the geology of western Colorado, in Bankey, Viki ed., Resource potential and geology of the Grand Mesa, Uncompahgre, and Gunnison National Forests and Vicinity, Colorado: U.S. Geological Survey Bulletin 2213-B, p. 11-30.

Ferguson, R.I., 1986, River loads underestimated by rating curves: Water Resources Research: v. 22, no. 1, p. 74-76.

Finney, D.J., 1941, On the distribution of a variate whose logarithm is normally distributed: Supplement to the Journal of the Royal Statistical Society, v. 7, p. 155-161.

Fishman, M.J., and Friedman, L.C., 1989, Methods for determination of inorganic substances in water and fluvial sediments: U.S. Geological Survey Techniques of WaterResources Investigations, book 5, chap. A1, available online at http://pubs.usgs.gov/twri/twri5-al/html/pdf.html, 545 p.

Fry, J.A., Coan, M.J., Homer, C.G., Meyer, D.K., and Wickham, J.D., 2009, Completion of the National Land Cover Database 1992-2001 land cover change retrofit product: U.S. Geological Survey Open-File Report 2008-1379, 18 p.

Garbarino, J.R., Kanagy, L.K., and Cree, M.E., 2006, Determination of elements in natural-water, biota, sediment and soil samples using collision/reaction cell inductively coupled plasma-mass spectrometry: U.S. Geological Survey Techniques and Methods, book 5, sec. B, chap. 1, available online at http://pubs.usgs.gov/tm/2006/tm5b1/, 88 p.

Green, G.N., 1992, The digital geological map of Colorado in Arc/Info format: U.S. Geological Survey Open-File Report 92-0507, scale 1:500,000.

Hem, J.D., 1985, Study and interpretation of the chemical characteristics of natural water, third edition: U.S. Geological Survey Water-Supply Paper 2254, 249 p.

Helsel, D.R. and Hirsch, R.M, 2002, Statistical methods in water resources: U.S. Geological Survey Techniques of Water-Resources Investigations, book 4, chapter A3, 522 pages. 
Hirsch, R.M., Alexander, R.B., and Smith, R.A., 1991, Selection of methods for the detection and estimation of trends in water quality: Water Resources Research, v. 27, no. 5, 5p. 803-813.

Homer, C., Huang, C., Yang, L., Wylie, B.K., and Coan, M., 2004, Development of a 2001 National Land Cover Database for the United States: Photogrammetric Engineering and Remote Sensing, v. 70, no. 7, p. 829-840.

Iorns, W.V., Hembree, C.H., and Oakland, G.L., 1965, Water resources of the Upper Colorado River Basin-Technical report: U.S. Geological Survey Professional Paper 441, $370 \mathrm{p}$.

Kanzer, D., and Merritt, D., 2008, The salinity control story of the Upper Colorado River Basin illustrated by case studies: 2nd International Salinity Forum, Adelaide, Australia, 4 p.,

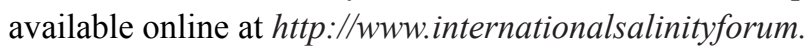
org/14_final.html.

Kendall, M.G., 1975, Rank correlation methods, second edition: London, Charles Griffin, 202 p.

Kenney, T.A., Gerner, S.J., Buto, S.G, and Spangler, L.E., 2009 , Spatially referenced statistical assessment of dissolved-solids load sources and transport in streams of the Upper Colorado River Basin: U.S. Geological Survey Scientific Investigations Report 2009-5007, 50 p.

Leib, K.J., and Bauch, N.J., 2008, Salinity trends in the Upper Colorado River Basin upstream from the Grand Valley Salinity Control Unit, Colorado, 1986-2003: U.S. Geological Survey Scientific Investigations Report 2007-5288, $21 \mathrm{p}$.

Liebermann, T.D., Middelburg, R.F., and Irvine, S.A., 1987, User's manual for estimation of dissolved-solids concentrations and loads in surface water: U.S. Geological Survey Water-Resources Investigations Report 84-4124, 51 p.

Liebermann, T.D., Mueller, D.K., Kircher, J.E., and Choquette, A.F., 1989, Characteristics and trends of streamflow and dissolved solids in the Upper Colorado River Basin, Arizona, Colorado, New Mexico, Utah, and Wyoming: U.S. Geological Survey Water-Supply Paper 2358, 64 p.

Likes, J., 1980, Variance of the MVUE for lognormal variance: Technometrics, v.22, no. 2, p. 253-258.

Mayo, J.W., 2008, Estimating the effects of conversion of agricultural land to urban land on the deep percolation of irrigation water in the Grand Valley, western Colorado: U.S. Geological Survey Scientific Investigations Report 2008-5086, 71 p., available online at http://pubs.usgs.gov/ sir/2008/5086/.
Moore, J.L., 2011, Effects of land use change on salinity and selenium loading in Montrose Arroyo, western Colorado, from 1992 to 2010: U.S. Geological Survey Scientific Investigations Report 2011-5106.

Mueller, D.K., and Osen, L.L., 1988, Estimation of natural dissolved-solids discharge in the Upper Colorado River basin, Western United States: U.S. Geological Survey Water-Resources Investigations Report 87-4069, 62 p.

Olson, S.A., and Norris, J.M., 2005, U.S. Geological Survey Streamgaging... from the National Streamflow Information Program: U.S. Geological Survey Fact Sheet 2005-3131, 4 p., available online at $h t t p: / / p u b s . u s g s . g o v / f s / 2005 / 3131 /$.

Phillips, J.V., and Tadayon, Saeid, 2006, Selection of Manning's roughness coefficient for natural and constructed vegetated and non-vegetated channels, and vegetation maintenance plan guidelines for vegetated channels in central Arizona: U.S. Geological Survey Scientific Investigations Report 2006-5108, 41 p., available online at $h t t p: / / p u b s$. usgs.gov/sir/2006/5108/.

Prairie, J.R., Rajagopalan, B., Fulp, T.J., Zagona, E.A., 2005, Statistical nonparametric model for natural salt estimation: Journal of Environmental Engineering, v. 131, no. 1, p. $130-138$.

PRISM Climate Group, Oregon State University, http://prism.oregonstate.edu, created February 4, 2004.

Rantz, S.E., and others, 1982, Measurement and computation of streamflow-Volume 1, Measurement of stage and discharge: U.S. Geological Survey Water-Supply Paper $2175,284 \mathrm{p}$.

Runkel, R.L., Crawford, C.G., and Cohn, T.A., 2004, Load Estimator (LOADEST): A FORTRAN program for estimating constituent loads in streams and rivers: U.S. Geological Survey Techniques of Water-Resources Investigations, book 4, chap. A5, 69 p.

Smith, R.A., Hirsch, R.M., and Slack, J.R., 1982, A study of trends in total phosphorus measurements at NASQAN stations: U.S. Geological Survey Water-Supply Paper 2190, $34 \mathrm{p}$.

Sturm, T.W., 2010, Open channel hydraulics, second edition: New York, McGraw-Hill Companies, Inc., 546 p.

Techni Graphic Systems, Inc., 2004, Colorado Decision Support Systems, http://cdss.state.co.us/DNN/GIS/tabid/67/ Default.aspx, accessed September 28, 2010.

TIBCO Software Inc., 1998-2008, Spotfire S+ Release 8.1: Somerville, Mass.

Tweto, Ogden, comp., 1979, Geologic map of Colorado: U.S. Geological Survey State Geologic Map, scale 1:500,000 (reprinted). 
U.S. Census Bureau, 2010, Population finder, http://www.census.gov/, accessed August 17, 2010.

U.S. Department of Agriculture, 2007, Lower Gunnison Unit Colorado River Salinity Control Project, Natural Resources Conservation Service Annual Report, accessed March 24, 2009 at $h t t p: / / w w w . u s b r . g o v / u c / p r o g a c t / s a l i n i t y / p d f s /$ LGCOFY07SalinityMEReport.pdf.

U.S. Department of Agriculture, 2010, Colorado River Basin Salinity Control Program, Natural Resources Conservation Service, accessed June 21, 2012 at http://www.nrcs.usda. gov/wps/portal/nrcs/detail/national/programs/alphabetical/ ?\&cid=stelprdb1044198.

U.S. Geological Survey, variously dated, National field manual for the collection of water-quality data: U.S. Geological Survey Techniques of Water-Resources Investigations, book 9, chaps. A1-A9., 2 volumes variously paged, available online at http://pubs.water.usgs.gov/twri9A.

Vogelmann, J.E., Howard, S.M., Yang, L., Larson, C.R., Wylie, B.K., and Van Driel, J.N., 2001, Completion of the 1990's National Land Cover Data Set for the conterminous United States: Photogrammetric Engineering and Remote Sensing, v. 67, no. 6, p. 650-662.

Wagner, R.J., Mattraw, H.C., Ritz, G.F., and Smith, B.A, 2000, Guidelines and standard procedures for continuous waterquality monitors: Site selection, field operation, calibration, record computation, and reporting: U.S. Geological Survey Water-Resources Investigations Report 00-4252, $53 \mathrm{p}$.

Western Regional Climate Center, 2010, Colorado climate summaries: Information available on web, accessed August 17, 2010, http://www.wrcc.dri.edu/. 

Appendix 
Table 7. Properties from the single linear regression of specific conductance and salinity for selected U.S. Geological Survey streamflow-gaging stations within the Gunnison River Basin, Colorado.

[Response variable is sum of constituents in milligrams per liter; SC coefficient, the coefficient multiplied by specific conductance, where specific conductance is in microseimens per centimeter; $\mathrm{R}^{2}$, coefficient of determination; $\mathrm{N}$, number of samples used to develop the regression; ratio, ratio of salinity concentration to specific conductance that was calculated using the existing samples]

\begin{tabular}{|c|c|c|c|c|c|}
\hline $\begin{array}{c}\text { U.S. Geological } \\
\text { Survey } \\
\text { streamflow- } \\
\text { gaging station } \\
\text { number, } \\
\text { all figures }\end{array}$ & $\begin{array}{c}\text { Y-axis } \\
\text { intercept }\end{array}$ & $\begin{array}{c}\text { SC } \\
\text { coefficient }\end{array}$ & $\mathbf{R}^{2}$ & $\mathbf{N}$ & Ratio \\
\hline \multicolumn{6}{|c|}{ Study period water years 1989-2004 } \\
\hline 09114500 & -0.760 & 0.580 & 97.7 & 14 & 0.58 \\
\hline 09128000 & 16.18 & 0.499 & 88.0 & 58 & 0.59 \\
\hline $09132500^{1}$ & 28.29 & 0.418 & 65.1 & 55 & ${ }^{1} 0.64$ \\
\hline 09144250 & -45.41 & 0.740 & 92.6 & 24 & 0.67 \\
\hline 09146200 & -40.34 & 0.729 & 99.4 & 63 & 0.65 \\
\hline 09147500 & -38.67 & 0.738 & 92.6 & 31 & 0.66 \\
\hline 09149500 & -145.9 & 0.820 & 94.8 & 117 & 0.72 \\
\hline 09152500 & -71.62 & 0.767 & 98.9 & 146 & 0.67 \\
\hline \multicolumn{6}{|c|}{ Study period water years 1989-2007 } \\
\hline 09114500 & -0.760 & 0.580 & 97.7 & 14 & 0.58 \\
\hline 09128000 & 16.18 & 0.499 & 88.0 & 58 & 0.59 \\
\hline $09132500^{1}$ & 28.29 & 0.418 & 65.1 & 55 & ${ }^{1} 0.64$ \\
\hline 09146200 & -40.34 & 0.729 & 99.4 & 75 & 0.65 \\
\hline 09152500 & -70.58 & 0.767 & 98.9 & 165 & 0.67 \\
\hline
\end{tabular}

${ }^{1}$ The regression developed for site 09132500 used the entire period of record (water years 1977-2010) because there were only two samples during either study period. 
Table 8. Model coefficients and statistical diagnostics from regression analysis for salinity concentrations at selected at U.S. Geological Survey streamflow-gaging stations within the study area.

[Response variable is natural-log transformed salinity load in tons; Ln, natural logarithm; Q, streamflow; *, centered values; sin, sine function; Cos, cosine function; k, positive integer used in seasonality variables; T, seasonal time; t, decimal time in decimal years; ERV, estimated residual variance; SCR, serial correlation of residual; $\mathrm{R}^{2}$, coefficient of determination; N, number of data points; --, variables not used in the regression because they were not statistically significant; ${ }^{\prime}, \mathrm{p}$-value greater than 0.05 but the term was included in the final regression]

\begin{tabular}{|c|c|c|c|c|c|c|c|c|c|c|c|c|c|c|c|c|c|}
\hline \multirow{3}{*}{$\begin{array}{l}\text { U.S. Geological } \\
\text { Survey stream- } \\
\text { flow-gaging } \\
\text { station number, } \\
\text { figures } 1-5\end{array}$} & \multirow{3}{*}{$\begin{array}{c}\text { Y-axis } \\
\text { intercept }\end{array}$} & \multirow{2}{*}{\multicolumn{3}{|c|}{ Streamflow }} & \multicolumn{6}{|c|}{ Seasonal terms } & & & & & & & \\
\hline & & & & & \multicolumn{4}{|c|}{$k 2 \pi T, k=2$} & \multicolumn{2}{|c|}{$k 2 \pi T, k=3$} & \multicolumn{3}{|c|}{ Decimal time } & \multicolumn{4}{|c|}{ Statistical diagnostics } \\
\hline & & $\begin{array}{l}(\operatorname{Ln} 0- \\
\left.\operatorname{Ln} 0^{*}\right)\end{array}$ & $\begin{array}{l}(\operatorname{Ln} 0- \\
\left.\operatorname{Ln} 0^{*}\right)^{2}\end{array}$ & $\mathbf{0}^{*}$ & Sin & Cos & Sin & Cos & Sin & Cos & $\left(\mathrm{t}-\mathrm{t}^{*}\right)$ & $\left(t-t^{*}\right)^{2}$ & $t^{*}$ & ERV & SCR & $\mathbf{R}^{2}$ & $\mathbf{N}$ \\
\hline \multicolumn{18}{|c|}{ Study period water years 1986-2003 } \\
\hline 09152500 & 6.141 & -0.557 & -- & 2,563 & -0.214 & -0.037 & -- & -- & 0.036 & -0.012 & -0.013 & -- & 1994.60 & 0.019 & 0.133 & 91.2 & 239 \\
\hline \multicolumn{18}{|c|}{ Study period water years 1989-2004 } \\
\hline 09114500 & 4.684 & -0.196 & -0.022 & 877 & ${ }^{\#-0.012}$ & -0.101 & -0.039 & 0.066 & -- & -- & -- & -- & $1,996.30$ & 0.004 & 0.019 & 79.7 & 142 \\
\hline 09124500 & 4.566 & -0.126 & -- & 111 & -- & -- & ${ }^{\#-0.014}$ & -0.027 & -- & -- & 0.010 & -- & $1,996.76$ & 0.004 & 0.198 & 66.3 & 112 \\
\hline 09126000 & 4.411 & ${ }^{\#} 0.021$ & -- & 29 & ${ }^{\#-}-0.011$ & 0.066 & -- & -- & -- & -- & 0.006 & 0.002 & $1,997.33$ & 0.004 & 0.271 & 36.1 & 48 \\
\hline 09128000 & 4.706 & -0.050 & -- & 1,091 & 0.034 & ${ }^{\#} 0.017$ & -- & -- & -0.029 & 0.019 & ${ }^{\#} 0.001$ & 0.001 & $1,996.98$ & 0.006 & 0.443 & 42.5 & 202 \\
\hline 09132500 & 4.580 & -0.037 & -0.029 & 363 & ${ }^{\#-}-0.010$ & 0.156 & -- & -- & -- & -- & 0.005 & -0.002 & $1,996.57$ & 0.019 & 0.297 & 54.5 & 141 \\
\hline 09134000 & 5.632 & -0.193 & -0.045 & 16 & 0.253 & 0.382 & -- & -- & -- & -- & -0.008 & -0.005 & $1,996.54$ & 0.052 & 0.267 & 81.6 & 134 \\
\hline 09143000 & 4.232 & ${ }^{\#}-0.015$ & -- & 25 & 0.176 & 0.381 & -- & -- & -0.081 & 0.019 & -- & -- & $1,996.51$ & 0.031 & 0.315 & 74.6 & 121 \\
\hline 09143500 & 4.373 & -0.089 & ${ }^{\# 0} 0.022$ & 17 & & 0.263 & -0.094 & $\#-0.038$ & -0.086 & ${ }^{\#}-0.004$ & 0.009 & -0.003 & $1,996.30$ & 0.037 & 0.434 & 75.5 & 128 \\
\hline 09144250 & 5.917 & -0.371 & -- & 1,827 & -0.176 & ${ }^{\#}-0.017$ & ${ }^{\#} 0.013$ & -0.048 & -- & -- & -0.016 & -- & $1,996.87$ & 0.041 & 0.077 & 71.8 & 168 \\
\hline 09147000 & 5.945 & -0.256 & -0.040 & 30 & -0.061 & ${ }^{\#}-0.032$ & -- & -- & -0.058 & -0.106 & ${ }^{\#}-0.003$ & 0.002 & $1,997.03$ & 0.019 & 0.278 & 70.9 & 132 \\
\hline 09146200 & 5.821 & -0.402 & -0.063 & 195 & -0.033 & ${ }^{\#} 0.048$ & 0.069 & 0.040 & ${ }^{\#-0.030}$ & -0.079 & -0.006 & -- & $1,996.71$ & 0.020 & 0.093 & 90.1 & 195 \\
\hline 09147025 & 5.831 & -0.056 & -- & 154 & 0.157 & 0.047 & -0.062 & ${ }^{\#}-0.003$ & -- & -- & -0.007 & 0.003 & $1,996.60$ & 0.014 & 0.432 & 66.1 & 146 \\
\hline 09147500 & 5.848 & -0.121 & -- & 209 & 0.061 & 0.088 & -- & -- & -- & -- & -0.005 & 0.002 & $1,996.72$ & 0.020 & 0.444 & 60.6 & 173 \\
\hline 09149500 & 6.941 & -0.377 & -0.054 & 279 & -0.133 & 0.114 & 0.028 & 0.045 & -- & -- & -0.011 & -- & $1,996.88$ & 0.020 & 0.036 & 80.0 & 255 \\
\hline 09152500 & 6.118 & -0.551 & -- & 2,566 & -0.213 & -0.033 & 0.012 & -0.054 & -- & -- & -0.013 & -- & $1,996.78$ & 0.019 & 0.091 & 90.5 & 210 \\
\hline \multicolumn{18}{|c|}{ Study period water years 1989-2007 } \\
\hline 09114500 & 4.693 & -0.194 & -0.023 & 862.4 & ${ }^{\#-0.012}$ & -0.101 & -0.043 & 0.064 & -- & -- & 0.002 & -- & $1,997.82$ & 0.004 & 0.246 & 78.7 & 155 \\
\hline 09128000 & 4.713 & -0.049 & -- & 1,080 & 0.035 & ${ }^{\#} 0.014$ & ${ }^{\#} 0.005$ & -0.029 & -0.031 & 0.015 & ${ }^{\#} 0.002$ & 0.001 & $1,998.10$ & 0.006 & 0.542 & 44.9 & 224 \\
\hline 09132500 & 4.582 & ${ }^{\#} 0.019$ & -0.023 & 371 & -0.034 & 0.214 & 0.081 & -0.058 & -- & -- & ${ }^{\#} 0.003$ & -0.001 & $1,997.66$ & 0.016 & 0.298 & 61.3 & 158 \\
\hline 09146200 & 5.834 & -0.391 & -0.069 & 194 & -0.044 & 0.069 & 0.079 & 0.053 & -- & -- & -0.005 & -- & $1,997.71$ & 0.022 & 0.103 & 88.7 & 267 \\
\hline 09152500 & 6.118 & -0.553 & -0.038 & 2,631 & -0.220 & -0.032 & -- & -- & 0.031 & ${ }^{\#}-0.022$ & -0.008 & 0.001 & $1,998.60$ & 0.020 & -0.005 & 90.6 & 251 \\
\hline
\end{tabular}


Publishing support provided by:

Denver Publishing Service Center

For more information concerning this publication, contact:

Director, USGS Colorado Water Science Center

Box 25046, Mail Stop 415

Denver, CO 80225

(303) 236-4882

Or visit the Colorado Water Science Center Web site at: http://co.water.usgs.gov/ 
$\frac{\mathbb{2}}{8}$

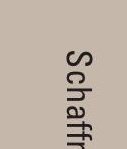

